\title{
An Analysis of the Concepts for Organization and Arranging with Furniture of Office Spaces
}

\author{
Zejnelabedin Aziri", Elena Nikoljski Panevski \\ Faculty of Design and Technologies of Furniture and Interior, Ss Cyril and Methodius University of Skopje, Skopje, Republic \\ of Macedonia
} Citation: Aziri Z, Nikoliski Panevski E. [An Analysis of the
Concepts for Organization and Arranging with Furniture of
Office Spaces]. SEE J Archit Des. 2016 May 04; 10021. [MSc]
[Macedonian] http://dx.doi.org/10.3889/seejad.2016.10021
Key words: divergent concept's; design; strategic planning;
office interior; ergonomics in office furniture; workplace;
capacities; limits; equipment's; office surrounding; interaction.
Correspondence: Zejnelabedin Aziri. Faculty of Design and
Technologies of Furniture and Interior, Ss Cyril and Methodius
University of Skopje, Skopje, Republic of Macedonia. E-mail:
zabidin.id@gmail.com, Zeynelabidin.id@gmail.com
Received: 11-Apr-2016; Revised: 21-Apr-2016; Accepted:
30-Apr-2016; Published: $04-$ May-2016
Copyright: @ 2016 Zejnelabedin Aziri. This is an open-access
article distributed under the terms of the Creative Commons
Attribution License, which permits unrestricted use,
distribution, and reproduction in any medium, provided the
original author and source are credited.
Competing Interests: The author have declared that no
competing interests exist. competing interests exist.

\section{Abstract}

BACKGROUND: With this paper it is made an analysis of the concepts for organization of the furniture and furnishing of office spaces. Two different aspects are beeing developed, which are intended for two different business structures and entities. The comparative approach for two functional divergent concepts allows clearer insight in the requests, the possibilities and the capacities of the premise for each specific purpose. Through the project analyzes the potential users of the office space would have detailed review and knowledge for the planning and the design procedures of the concrete space. The organization of the furniture and the remaining arrangement vary in the two project varieties created for them and are much depended on the analyzes of the anthropometric and ergonomic principles of design being applied in the development of the project varieties.

AIM: The aim of the ergonomic analyzes being shown in the paper is to get quality and comfortable working space, in which the human factor is very important.

RESULTS: Through better understanding of the ergonomic parameters, the designer can influence on the health and the safety in the working place. In fact, responsibility and task of each designer is to constantly follow the researches in the field of the ergonomic in order to apply, maintain and improve them while designing the furniture and the interior. In this paper the most frequent ergonomic problems are being covered appearing in separate characteristic working places. Also, the amount of communication and manipulation space is being mentioned. Moreover, the nodes with problematic connections are being mentioned and the opportunities to overcome them.

CONCLUSION: Only with quality understanding of the human factor, its working place, the equipment, the working environment and the interaction relationships which exist between them, could the furniture and the interiors be designed in healthy and safe manner to create effective and efficient working systems. 


\author{
Универзитет "Св. Кирил и Методиј“, \\ Факултет за дизајн и технологии на мебел и ентериер- \\ Скопје,Република Македонија
}

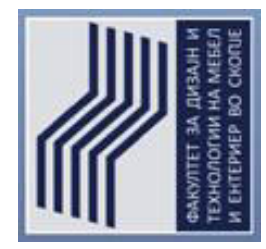

Зејнелабедин Азири

\title{
АНАЛИЗА НА КОНЦЕПТИТЕ НА \\ ОРГАНИЗАЦИЈА И ОПРЕМУВАҢЕ СО МЕБЕЛ КАЈ КАНЦЕЛАРИСКИТЕ ПРОСТОРИ
}

- магистерски труд -

Скопје,2015 


\section{СОДРЖИНА}

Апстракт

Abstract

Вовед

Методологија на научно истражување

1. Стратешко планирање и намена на просторот.....................................................11

1.1 Местоположба, локација, студија и структура.......................................................11

1.1.1 Стратешко планирање на локацијата наменета за ентериер на новинска агенција....................................................................................12

1.1.2 Стратешко планирање на локацијата наменета за ентериер на правна канцеларија.

1.2 Физибилити студијаза намената на просторот..................................................14

2. Организација на проектот......................................................................................... 29

2.1 Дефинирање на потребите и целите на проектот.................................................29

2.2 Собирање на информации релевантни за организацијата на проектот...............30

2.3 Развој на прелиминарен распоред на проектот и предвиден буџет.....................31

3. Анализа на ентериерот на канцелариските простори..................................................32

3.1 Анализа на проектот за ентериер на канцеларискиот простор предвиден за организација на новинската агенција..............................................................37

3.1.1 Проценка на големината на потребниот канцелариски простор на новинската агенција.................................................................................37

3.1.2 Планирање на ентериерот на новинската агенција.................................50

3.1.3 Опремувањесо мебел на канцеларискиотпростор наменет за новинската агенција.....................................................................................53

3.2 Анализа на проектот заентериерот на канцеларискиот простор наменет заправнаканцеларија.................................................................................................5

5

3.2.1 Проценка на големината на потребниот простор за правна канцеларија..................................................................................................55

3.2.2 Планирање на ентериерот на канцеларискиот простор на правна канцеларија..........................................................................................63

3.2.3 Опремување на канцеларискиот простор на правна канцеларијасо мебел.

4. Анализа на антропометријските и ергономските параметри применети во опремување на ентериерите за работа со канцеларијска опрема..........................66

5. Анализа на одделни примери на ентериери на канцелариски простории

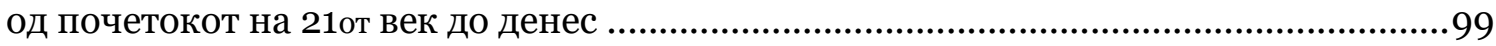

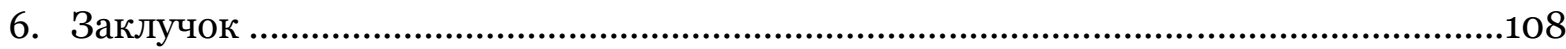

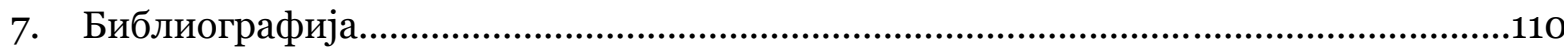




\title{
АНАЛИЗА НА КОНЦЕПТИТЕ НА ОРГАНИЗАЦИЈА И ОПРЕМУВАҢЕ СО МЕБЕЛ КАЈКАНЦЕЛАРИСКИТЕ ПРОСТОРИ
}

\begin{abstract}
Апстракт
Во трудот е направена анализа на концептите на организацијата на мебел и опремување на канцелариските простори. Разработени се два различни пристапи, наменети за две различни деловни структури, објекти и субјекти. Компаративниот пристап за два функционално дивергентни концепта овозможува појасен увид во барањата, можностите и капацитетите на објектот за секоја од конкретно зададените намени. Преку проектните анализи потенцијалните корисници на канцеларискиот простор би имале детален преглед и сознанија за постапките на планирање и проектирање на конкретниот простор. Распоредот на мебелот и останатото уредување варираат во двете варијанти создадени за нив и во многу зависат од анализите на антропометриските и ергономските принципи на проектирање применети во анализата.

Целта на ергономските анализи прикажани во трудот е да се добие квалитетен, комфорен работен простор, во кој човечкиот фактор е многу важен. Преку подобро разбирање на параметрите на ергономијата, проектантот може да влијае на здравјето и сигурноста на работното место.Всушност, обврска и задача на секој проектант е постојано да ги следи истражувањата од областа на ергономијата за да ги примени, одржи и подобри при дизајнот на мебел и ентериер.Во трудот се опфатени најчестите ергономски проблеми, на одделни карактеристични работни места, количеството простор за комуникација и манипулација, јазлите со проблематични конекции и можностите за нивно надминување.Само со квалитетно разбирање на човечкиот фактор, на неговото работно место, на екипираноста, работното опкружување и на интеракциските односи кои постојат помеѓу нив, може да се дизајнираат мебелот и ентериерите здраво и сигурно и на тој начин да креираат ефективни и продуктивни работни системи.
\end{abstract}

Клучни зборови:дивергентни концепти, дизајн,стратешко планирање,канцеларијски ентериери, ергономија на канцеларискиот мебел, работно место, капацитети, лимити, екипираност, работно опкружување, интеракција. 


\title{
AN ANALYSIS OF THE CONCEPTS FOR ORGANIZATION AND ARRANGING WITH FURNITURE OF OFFICE SPACES
}

\begin{abstract}
With this paper it is made an analysis of the concepts for organization of the furniture and furnishing of office spaces. Two different aspects are beeing developed, which are intended for two different business structures and entities. The comparative approach for two functional divergent concepts allows clearer insight in the requests, the possibilities and the capacities of the premise for each specific purpose. Through the project analyzes the potential users of the office space would have detailed review and knowledge for the planning and the design procedures of the concrete space. The organization of the furniture and the remaining arrangement vary in the two project varieties created for them and are much depended on the analyzes of the anthropometric and ergonomic principles of design being applied in the development of the project varieties.

The aim of the ergonomic analyzes being shown in the paper is to get quality and comfortable working space, in which the human factor is very important. Through better understanding of the ergonomic parameters, the designer can influence on the health and the safety in the working place. In fact, responsibility and task of each designer is to constantly follow the researches in the field of the ergonomic in order to apply, maintain and improve them while designing the furniture and the interior. In this paper the most frequent ergonomic problems are being covered appearing in separate characteristic working places. Also, the amount of communication and manipulation space is being mentioned. Moreover, the nodes with problematic connections are being mentioned and the opportunities to overcome them. Only with quality understanding of the human factor, its working place, the equipment, the working environment and the interaction relationships which exist between them, could the furniture and the interiors be designed in healthy and safe manner to create effective and efficient working systems.
\end{abstract}

Key words: divergent concept's, design, strategic planning, office interior, ergonomics in office furniture, workplace, capacities, limits, equipment's, office surrounding, interaction. 


\section{ВОВЕД}

Анализирајќи го односот на корисниците и количеството работното време кое го минуваат во канцеларискиот простор се доаѓ до сознание дека корисниците денес подолго време минуваат во канцеларија отколку во минатото, од една страна, од друга страна современите концепти на менаџирање на работењето овозможуваат работата да биде завршена од различни места, незадолжително од конкретното работно место. Поточно корисниците не се веќе директно локацијски зависни од реалниот, брендираниот простор на нивната канцеларија. Анализирајќ́ го пак минатото и искуствата во организацијата на канцеларискиот простор се согледувадека концептот на минување подолго време на работното место има своја традиција и историја.

Подемот во развојот на ентериеритекај канцелариските простори секогаш е причински-последично поврзан со развојот на индустријата и технологијата. Сепак концептот на минување подолго време на работното место датира од периодот пред технолошката револуција, и поради тоа би можел да се протолкува и анализира со параметрите кои се однесуваат на индивидуалниот пристап во работењето и особено во временските и локацијските потребите за обавување на истото. Анализирајќи го од историјски аспект просторот за работа, кој денес главно се нарекува канцелариски завземал различни форми и димензии. Во времето на класичната антика канцелариските простори често биле дел од една палата или храм. Додека во времето на средниот век (1000-13оогодина) се поголема била примената на канцелариски простор кој се официјализирал на повисоко ниво и просторите за работа биле третирани како јавни. Значи канцелариските простори започнувале да се третираат како јавни установи, отворени за пристап на корисниците.

Многу подоцна со општествено економскиот развој и креирањето на првите големи организации (корпорации и концерни) во 18-ти век, за првпат се изградени наменски канцелариски простори, сместени во канцеларијски објекти. Со интензивирање на индустриската револуција во 18-тиот и 19-тиот век, индустриите како банкарството, железницата, осигурувањето, малопродажбата, трговијата со нафта како и телеграфијата драстично се развивале и зголемувале. Како резултат на тоа се јавила потреба од огромен број на службеници но исто така бил потребен и поголем канцелариски простор со цел да се сместат службениците.

Основната функција на канцеларискиот простор е да им овозможи на корисниците квалитетен и удобен простор за непречено извршување на работните задачи. Денес, просторот за работа ги прима функциите и активностите како што се читање, пишување и работа со компјутер.Во современи услови кога е невозможно да се определи реалниот број на компјутерски корисници, границите за разбирање и поимање на канцеларискиот простор се изменети. Благодарение на оптичките влакна, информациите патуваат со брзина на светлината, рушејќи ги бариерите на времето и просторот. Прогресивната трансформација на еден работник во некој од сервисните сектори, од вработен во 
телекомпјутер кој повеќе не го напушта домот за да оди на работа, туку работи низ целиот свет од дома, сериозно влијае на концептот на организација на канцеларискиот простор.Ова е современ, вистински социолошки феномен, кој особено во развиените земји, рапидно се зголемува, носејќи ги со себе позитивните и негативните реперкусии на процесот. ${ }^{1}$

Токму, овој феномен ќе ја оневозможи, особено во иднина, поделбата на канцелариите, по просторни или хиерархиски принципи. Мебелот за опремување на канцелариските простории дури и да се употребува ротационо од страна на повеќе лица, работната маса и работниот столостануваат да бидат фундаментална компонента или клучните елементи во опремувањето на канцелариите. Соодветно на тоаво сегментот антропометриски и ергономски анализи во трудот се земени в предвид токму овие две клучни компоненти.

Растечката еволуција, прави новите работни маси да превземаат есенцијални форми (незадолжително квадратни), ослободени од стегите на 70-тите, сепак екипирани со низа современи додатоци способни да ги сместат најразличните современи технички компоненти иособено да се прилагодат на различни корисници со најразлични карактери. Едноставно, авторството нема веќ потреба да доаѓа до израз, преку претерување во формата и декорот, доколку наспрам нив се обезбеди, високо ниво на комфор и пристап до информациите, потоаи канали што нив ги сервисираат. Од таму можеби, само парчињата мебел со есенцијална типологија можат да ги примат,,на нозе,, овие шокови на адаптација, и трансформација, од една функција во друга, од еден консумент на друг.

Во зависност од целта и активностите кои одредена организација или претпријатие ги извршува се разликува и ентериерот како и опремата со која што канцеларискиот простор е опремен. Значи ентериерот се изведува така што да прилега на функцијата која се извршува во канцеларискиот простор. Ова се јавува како резултат на различните потреби на одредена организација или претпријатие. Токму поради тоа опремувањето и уредувањето воопшто на канцелариските простори е деликатно, од една страна имаме произвводство со стандардизирани димензии и производи (мебел за канцеларии, маси столови и останата опрема), а од друга страна многу различни, понекогаш и вон стандардот барања за уредување од страна на клиентите односно претпријатијата.

Се наметнува прашањето возможно ли е да се уреди канцелариски простор со оригинален дизајн карактеристичен само за одредена организација или претпријатие а при тоа да се користи стандарден мебел. На пример, кај канцеларискиот простор во наменет за новинска агенција со цел подобра комуникација помеѓу вработените најпожелно би било просторот да биде отворен. Додека кај канцеларискиот простор наменет за правни канцеларии очекувано е просторот на секој вработен да биде преграден и сосема засебен така што би се овозможила приватност на клиентите. Со цел подлабоко согледување на различностите помеѓу канцелариските простори наменети за две организации со различни активности и како истите се опремуваат на различен начин, во овој магистерски труд ќе се направи обид за компаративна анализа на опремување на канцелариски простор кај новинска агенција и кај правната канцеларија, со сите нивни посебности и заеднички вредности.

\footnotetext{
${ }^{1}$ http//: bbc.com/news/magazine/23372401
} 


\section{Методологија на истражување}

\section{Научна оправданост}

Поголемиот дел од канцелариските простори проектирани и организирани до 50тите години на минатиот век се планирани на начин кој анализиран од денешен аспект делува конвенционален. Примерите канцелариски простори од овој период зачувани до денес, зборуваат за конвенционалниот пристап при опремувањето. Големината на канцелариите и нивната местоположба зависи од нивото на вработениот во хиерархијата на компанијата и наќинот на организиција во дирекцијата во која што работи. Најчесто менаџерските и дирекционалните канцеларии се со најголема квадратура и на најдобрата ориентација во објектот. Останатите канцеларии за вработените би биле организирани согласно нивната работна задача. Овој начин на организација датира од деновите кога компаниите биле мали и немале многу вработени. Притоа, компанијата можела да си дозволи употреба на голем простор за канцеларии. Секоја соба односно простор претставувала канцеларија. Сите овие простори биле наместени долж sидовите на зградата поврзани комуникативно со ходник.

Работата во канцеларија претставува на некој начинистражување. Оваа работа вклучува читање и пишување и се повеќе комуникација со други лица.

Новите сознанија добиени од анализите на брзиот развој на комуникациската и информационата технологија имаа директно влијаније врз опремата кај канцелариските простори но исто така имаа придонес за создавање на нови софистицирани идеи во однос на дизајнот на мебелот кај канцелариските простори.

Измените во основниот модел на работа во канцеларијата денес се резултат на сеопфатната компјутеризација. Новото поимање за брзината на информациите и комуникацијата предизвикаа прогресивна трансформација на еден работник во некој од сервисните сектори, во вработен директно зависен од компјутер. Во таа насока канцелариите можат да бидат организирани од далеку, па дури и од дома, бидејќи вработениот може да работи низ целиот свет од дома. Оваа појава е современ, вистински социолошки феномен, кој особено во земјите од западна Европа, рапидно се зголемува. Токму, овој феномен ќе ја оневозможи, особено во иднина, поделбата на канцелариите, по просторни или хиерархиски принципи.Сепак, дури и да се употребува ротационо од страна на повеќе лица, работната маса, столот остануваат да бидат фундаментална компонента (клучни елементи) во опремувањето на канцелариите.

Примерите кои се предвидуваат да бидат обработени во овој магистерски труд се однесуваат на овој комплексен спој на современите технолошки можности од една страна и потребата од еден конвенционален, функционален и репрезентативен простор за канцелариите со две сосема различни намени.

Растечката еволуција, прави новите работни маси да превземаат ергономски погодни функционални додатоци, опремени така да можат да ги сместат покрај компјутерите уште и останатите современи технички компоненти, и особено да се прилагодат на различни корисници со најразлични карактери. 
Анализа на концептите на организација и опремување со мебел кај канцелариските простори магистерски труд Зејнелабедин Азири

Во современите концепти на организација на канцеларискиот простордизајнерите на мебел ги дефинираат и подобруваат концептите и трендовите на иднината преку дизајнирање на работна околина како 'telework', 'hotdesking', 'hottelling', 'desksharing', 'mobilworking'. Тие го напуштаат традиционалниот начин на уредување позади нив и се насочуваат кон нов начин на дизајнирање на канцелариски простор кој во новиот работен простор би му обезбедил поголема удобност на вработениот но и поефиксано завршување на работите. Со самото зголемување на брзината на развој на комникацијата и информациите се зголемува и удобноста при работа но и вредноста на човекот исто така. Еден од начините на концептирање на организацијата на мебелот и негово опремување во канцелариските простори претставува стратешкото планирање на просторот. Овој начин на планирање од страна на Rayfield J.K., е претставен како проактивен пристап кон дизајнот на просторот и неговото користење. Консументите, корисници на просторот, без разлика на нивната големина и без разлика дали просторот во кој тие функционираат е изнајмен или е во нивна сопственост, може да имаат придобивка преку обид за имплементирање на стратешкото планирање на просториите.

Во денешно време најголем проблем на консументите при работа е нивното реактивно однесување кон проблемите кои што се јавуваат при вршењето на своите активности. Една од најголемите причини се однесува на некомплетен и несоодветен процес на дизајнирање пред отпочнување со работа.

Преку анализа на концептите на организација и опремување корисниците би имале детален преглед врз просторот во кој би требало да работат, врз распоредот на мебелот и друг инвентар но и врз начинот на распоред на вработените во фирмата и какви услови се создадени за нив.

Преку овој метод се овозможува детална анализа на концептите на организација и опремување на мебел кај канцелариските простори.

Стратешкото планирање нуди одговор на следниве три прашања:

- Што поседува друштвото/организацијата/(претпријатието)

- Која е потребата на друштвото/организацијата/(претпријатието)

- Кој е пристапот што друштвото/организацијата /(претпријатието) го следи со цел достигнување на неговите цели

Како резултат на анализите се оформува план со кој што јасно ќе бидат дефинирани крајните цели на друштвото и стратегијата за нивно достигнување.

Притоа,просториитенадруштвото ќе бидат со соодветни димензии и соодветно дизајнирани но и обврските на фирмата ќе бидат исполнети на рентабилен начин.

\section{Предмет и цели на научното истражување}

Предмет на истражувањето во овој научен труд е: планирањето, проектирањето, уредувањето и опремувањето на даден канцелариски простор, за да може да прими две сосема различни функциии.Планирањето се предвидува најнапред поради тоа што предвидува изработка на физибилити студија за висината на инвестицијата, евентуалните додатни трошоци и предвидливиот повратен позитивен ефект од инвестицијата во нов соодветен и компатибилен на дејноста на компанијата простор.

Проектирањето се одвива според архитектонските параметри и прописи за проектирање на канцелариски простор, во случајот за две дивергентни функции. 
Анализа на концептите на организација и опремување со мебел кај канцелариските простори магистерски труд Зејнелабедин Азири

Уредувањето претставува компонента од проектирањето која следува или се изведува паралелно со истражувањата за функционално решение на просторот. Уредувањето и опремувањето на просторот со мебел можат да бидат фактори двигатели во процесот на проектирање на ентериерот и вице верса.

Покрај планирањето, проектирањето, уредувањето и опремувањето на даден канцелариски простор, предмет на истражувањето во магистерскиот труд ќе биде и ергономијата и антропометријата со посебен осврт на работното место, работната маса, работниот стол, нивните димензии и взаемното дејство помеѓу нив, човекот и просторот.

Дадени се некои аспекти за ергономските проблеми и примери, како и ефективни насоки за тоа што треба да се направи, при тоа истите да се одбегнат. Трудот ја анализира квалитетната врска на ергономијата со задачите, опремата, информациите и околината, како и фактот дали тие функционираат како една целина, при тоа внимавајќи на следните параметри:

1. За да се испита заемното дејство меѓу личноста и неговата работа, ергономијата мора да земе предвид многу аспекти, како на пример:

- како е завршена работата и барањата од работникот

- опремата која е користена (големината, обликот, соодветноста за задачата)

- информацијата која се користи (како е презентирана, кој е пристапот, како и промената)

- физичката околина (температура, влажност, светлина, врева и вибрации) и

- социјалната околина (како тимска работа и менаџмент кој поддржува)

2. Ергономијата ги зема предвид сите физички аспекти на личноста, како:

- големината на телото и обликот

- адаптивната вредност и силата

- држењето на телото

- сетилата (посебно видот, слухот и допирот) и

- напорот на мускулите, на зглобовите и на нервите.

3. Ергономијата исто така ги зема предвид и психолошките аспекти на личноста:

- менталните способности

- личноста

- знаењето и

- искуството

Со оценување на овие аспекти на луѓето, работата, опремата (мебелот) и работната околина (ентериерот) и интеракцијата помеѓу нив, дизајнерите се во можност да дизајнираат безбеден, ефективен и продуктивен работен систем.

Целта на овој труд е да преку земање за пример две друштва/организации/ (претпријатија) од различни сектори да се направи анализа на процесот на планирањето, проектирањето, уредувањето и опремувањето, односно дизајнирање на канцелариски простор, на два сосема различни начина и пристапи. Притоа, да се максимизира ефикасноста на процесот на дизајнирање и да се минимизира периодот потребен за решавање на потенцијалните проблеми кои што би се појавиле при работењето.

Поставената цел истражувањето врз ефикасноста на дизајнот кај канцелариските простори е импликативна за оваа тема и во трудот ги подразбира сите елементи на дизајнот: форма, димензија, боја, текстура, светло, пропорција, размер, рамнотежа, хармонија, композиција, модулараност. 


\section{Методи на научно истражување}

Во овој труд напаравена е анализа на две канцелариски простории сместени во Деловно Трговскиот Центар-ДтЦ Мавровка.Едната канцеларија претставува новинска агенција додека другата претставува правната канцеларија. Новинската агенција ке биде дизајнирана во затворен концепт додека правната канцеларија ќе биде дизајнирана во отворен концепт.

Истражувањето е спроведено со користење на неколку методи, кои овозможуваат на правилен начин да се дојде до информациите кои ни се потребни.

- Аналитички метод, претставува само прв чекор во истражувањето. Тежиштето се става на интензитетот со кој се одвива процесот на формирање и развој на архитектонскиот простор, во рамките на еден ист објект. следење на начините на видопизменување на ентериерот во зависност од корисниците кои се менувале.

- Историскиот метод, овозможува да се утврдат матриците на архитектонскиот објект и неговото урбанистичко опкружување за да се дојде до информации важни за потенцијалните ентериери. Со овој метод се утврдуваат факторите кои влијаеле во формирањето и дефинирањето на урбанистичкиот агол сегмент од Скопје, каде што е сместен објектот тц. Мавровка, во кој се разработува еден ентериер кој е предмет на интерес на трудот. Утврден е и историскиот развој и трансформациите кои ги претрпела оваа зона/населба како резултат на различните опшествено економски услови. При тоа секој различен период оставил одредена трага и свој белег, па денешната состојба на овој агол од градот претставува симбиоза на спецификации на различни временски периоди.

- Нормативен метод, со кој се врши конкретизирање на информациите, односно се врши преод од општото кон конкретното.

- Метод на набљудување, со кој преку самостојно набљудување и истражување на зададениот простор, се доаѓa до дефинициите за основните архитектонски карактеристики и ентериерни барања на објектот.

- Метод на анализа и синтеза, со кој е извршена анализа на просторната организација на објектот тц. Мавровка, како и анализа на конструктивните системи и елементи. 
Анализа на концептите на организација и опремување со мебел кај канцелариските простори магистерски труд Зејнелабедин Азири

\section{1. СТРАТЕШКО ПЛАНИРАҢЕ}

Стратешкото планирање на просторот претставува проактивен пристап кон дизајнот на просторот и негово користење. ${ }^{2}$ Друштвата (компаниите) без разлика на нивната големина и без разлика дали просторот во кој тие функционираат е изнајмен или е во нивна сопственост, може да ги користат придобивкитеод процесот на имплементација на стратешкото планирање на просториите.

На овој начин тие би постигнале контрола врз цените на нивните простории и би ја зголемиле продуктивноста на вработените преку дизајн на посоодветни простории за работа.Со други зборови, целта на спроведување на стратешкото планирање е да се даде одговор на следниве три основни прашања: ${ }^{2}$

- Што поседува друштвото?

- Која е потребата на друштвото?

- Кој е пристапот кој друштвото го следи со цел достигнување на неговите долгорочни потреби?

Како резултат, би се добил план кој што јасно ќе ги дефинира крајните цели на друштвото и стратегијата за нивно достигнување. Стратегијата треба да ги дефинира одредените активности кои што ќе се одвиваат во просториите, трошоците кои што би произлегле, и план за нивно имплементирање. Ефикасно извршување на планот би му овозможил на менаџментот на друштвото да работи кон остварување на поставената цел и да функционираат проактивно наместо по потреба со цел извршување на тековните обврски. Како резултат на стартешкото планирање, просториите на друштвото ќе бидат со соодветни димензии и соодветно дизајнирани но и нивните обврски ќе бидат исполнети на рентабилен начин (со помал трошок). ${ }^{2}$

\section{1 Местоположба, локација, студија и структура}

Друштвата кои се предмет на анализа во овој труд се наоѓаат во деловно трговскиот центар-ДТЦ Мавровка. ДТЦ Мавровка претставува објект кој се наоѓа на околу еден километар растојание од плоштадот Македонија во Скопје. Објектот е наменет за деловни и трговски потреби и поточно се наоѓ на аголот од раскрсницата на булеварите „Гоце Делчев,, и „Крсте Петков Мисирков,,. Објектот е изграден во 90-те години со цел да излезе вопресрет на потребите на трговците и потрошувачите. Во негова близина се наоѓa Старата скопска чаршија и пазариштето “Бит-пазар“ но исто така и важни институции во Македонија како Врховниот суд, Апелациониот суд, Националната и универзитетска библиотека „Св. Климент Охридски“, Економскиот, Правниот и Филолошкиот факултет при универзитетот „Св. Кирил и Методиј“ и националната телевизија на Македонија, „Македонска радио телевизија“.На соодветно растојание исто така се наоѓаат Македонската академија на науките и уметностите, Македонската Опера и Балет и Универзитетот на Југоисточна Европа (претставништво во Скопје).

Подолу е прикажан план во А3 формат на ДтЦ Мавровка со околните објекти урбанистичка подлога.

\footnotetext{
${ }^{2}$ Office Interior Design Guide, Rayfield K. Julie, стр.3
} 
Анализа на концептите на организација и опремување со мебел кај канцелариските простори магистерски труд Зејнелабедин Азири

Стр. 12 


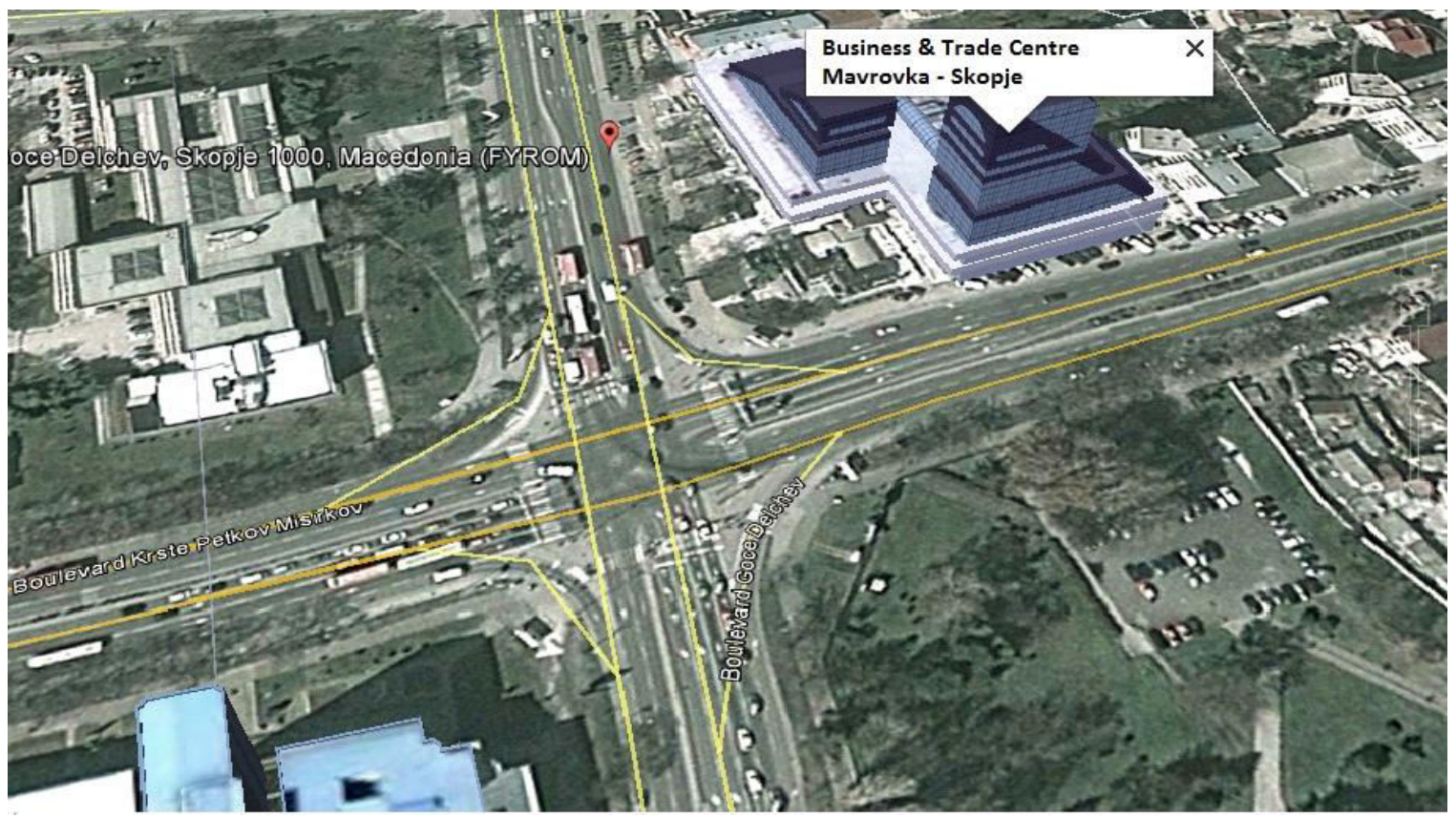

Слика.1 Перспектива кон просторот на ДТЦ „Мавровка“

Разработени се два различни пристапи, наменети за две различни деловни структури и субјекти. Компаративниот пристап за два функционално дивергентни концепта овозможува појасен увид во барањата, можностите и капацитетите на објектот за секоја од конкретните намени. Преку проектните анализи потенцијалните корисници на канцеларискиот простор би имале детален преглед и сознанија за постапките на планирање и проектирање на конкретниот простор. Распоредот на мебелот и останатото уредување варираат во двете варијанти создадени за нив и во многу зависат од анализите на антропометриските и ергономските принципи на проектирање применети во анализата.

\subsection{1.Стратешко планирање на локацијата наменета за ентериер на новинска агенција}

Друштвото се наоѓa на осми кат во ДТЦ Мавровка. Тоа претставува новинска агенција која што издава неделник на турски јазик и месечник на албански јазик. Друштвото има стратешка местоположба на својот простород аспект на брзо дознавање на некои од најважните настани поради блискоста со повеќето важни институции во Македонија како на пример: Старата скопска чаршија и пазариштето "Бит-пазар“ но исто така и важни институции во Македонија како Врховниот суд, Апелациониот суд, Националната и универзитетска библиотека „Св. Климент Охридски“, Економскиот, Правниот и Филолошкиот факултет при универзитетот „Св. Кирил и Методиј“ и националната телевизија на Македонија, „Македонска радио телевизија“. Притоа може да се заклучи дека ова може да послужи како добар пример за избор на локација на објект на едно друштво соодветно на неговата дејноста.

Покрај поволната местоположба исто така канцеларијата на друштвото позицијски се наоѓ⿱ на на повисока катност во постојниот објект т.ц. Мавровка, место што му 
Анализа на концептите на организација и опремување со мебел кај канцелариските простори магистерски труд Зејнелабедин Азири

овозможува полесна и поширока достапност до очите на јавноста, преку можност за истакнување на логото на компанијата на фасадата од објектот.

\subsection{2 Стратешко планирање на локацијата наменета за ентериер на правна канцеларија}

Правната канцеларија претставува друштво кое што нуди разни услуги на своите клиенти од областа на правото во зависност од нивните потреби. Како и претходното друштво, исто така и овадруштво има стратешка местоположба на својот простор од аспект на голема блискост со Врховниот суд и Апелациониот суд. Може да се заклучи дека изборот на оваа локација за просторот на друштвото може да послужи како добар пример за избор на локација на објект на едно друштво соодветно на неговата дејност.

\section{2 Физибилити студија - за намената на просторот}

Стратешкото планирање на просторот на некој начин претставува и физибилити студија за намената на просторот на друштвото. Бидејќи стратешкото планирање нуди јасна слика за тоа што работи друштвото, што сака да постигне и која е неговата стратегија за постигнување на нејзината цел. Со други зборови, како резултат на стратешкото планирање ќе има еден преглед на причините поради кои друштвото ги применува своите активности и стратегија како да ги исполни своите цели на најсоодветен и рентабилен начин. Стратешкото планирање се изведува во шест чекори меѓу кои се следниве:3

1. Преглед и евалуација на тековната ситуација на објектот

2. Идентификување на потребите на претпријатијата и корисниците

3. Анализа на навики на користење и управување со канцелариските простори, кај нас

4. Дефинирање на постапки и критериуми за соодветен избор на мебел за опремување на канцелариските простори

5. Развивање и евалуација на алтернативи

\section{3Преглед и евалуација на тековната ситуација}

Во овој дел од стратешкото планирање се добиваат информации за целите на друштвото преку преглед на нивниот бизнис план или друг документ каде што јасно се дефинираницелите на друштвото.4Исто така, во овој дел, треба да се соберат сите достапни информацииза претходните и тековните активности, политики, положби и трендови кои што друштвото ги следи. Целта на овој преглед е да се добие што е можно поголем увид во работењето на друштвото и да се дознае што фукнционирало коректно, а што не функционирало во минатото при обидот за достигнување на потребите на друштвото.

Како резултат на анализата на тековната ситуација треба да се добијат информации во однос на:

\footnotetext{
${ }^{3}$ Office Interior Design Guide, Rayfield K. Julie, стр.4

${ }^{4}$ Office Interior Design Guide, Rayfield K. Julie, стр.5
} 
Анализа на концептите на организација и опремување со мебел кај канцелариските простори магистерски труд Зејнелабедин Азири

- Простор за инвентар

- Стандарди за планирање и мебел на инвентарот

- Политики за недвижности

\section{Простор за инвентар}

Целта на испитување на просторот за инвентар е да дознае вкупниот простор достапен на организацијата. При испитување на вкупниот достапен простор во предвид треба да се земат следниве карактеристики како, локација, бруто големина и зафатнина во квадратни метри, ефикасност на просторот, вид, корисници, состојба на сопственост, да се утврди колку долго организацијата ќе има поволна и економска корист на просторот, цена, вклучувајќи и онаа од изнајмените простори, амортизација, трошоци при работење, оддржување и поправка, состојба на просториите и нејзиниот можен период на употребливост, вклучувајќ́ ги и системите за поддршка (греење, вентилација и климатизација, распределба на струја), останати материјални и нематеријални квалитети на просторот (достапност до јавен превоз, достсапност на паркинг место). 4

Состојбата на сопственост на просторот исто така треба да ги идентификува датумите кога истекуваат договорите за изнајмување, да развие долгорочен план за имплементација на стратешкиот план. 5

Резимето на испитувањето на потребниот простор за инвентар графички е илустрирано во Графикон1, 2, 3 и 4.

1). Во Графикон 1, прикажана е сопственоста на секој објект одделно и како истата се менува од година на година. На пример, дирекцијата цело време се планира да биде во сопственост на организацијата додека Местото А после првата година планира да се продаде и истото да биде сместено во објект под наем.

2). Во Графикон 2, прикажано е движењето на трошоците за изнајмување на просториите;

3). Во Графикон 3, прикажан е уделот на сите објекти во вкупниот простор.

4). Во Графикон 4, претставена е површината на просторот за инвентар кој што е достапен за да ги задоволи идните потреби на организацијата.

\footnotetext{
${ }^{4}$ Office Interior Design Guide, Rayfield K. Julie, стр.6 и 7

${ }^{5}$ Office Interior Design Guide, Rayfield K. Julie, стр.6 и 7
} 
Анализа на концептите на организација и опремување со мебел кај канцелариските простори магистерски труд Зејнелабедин Азири

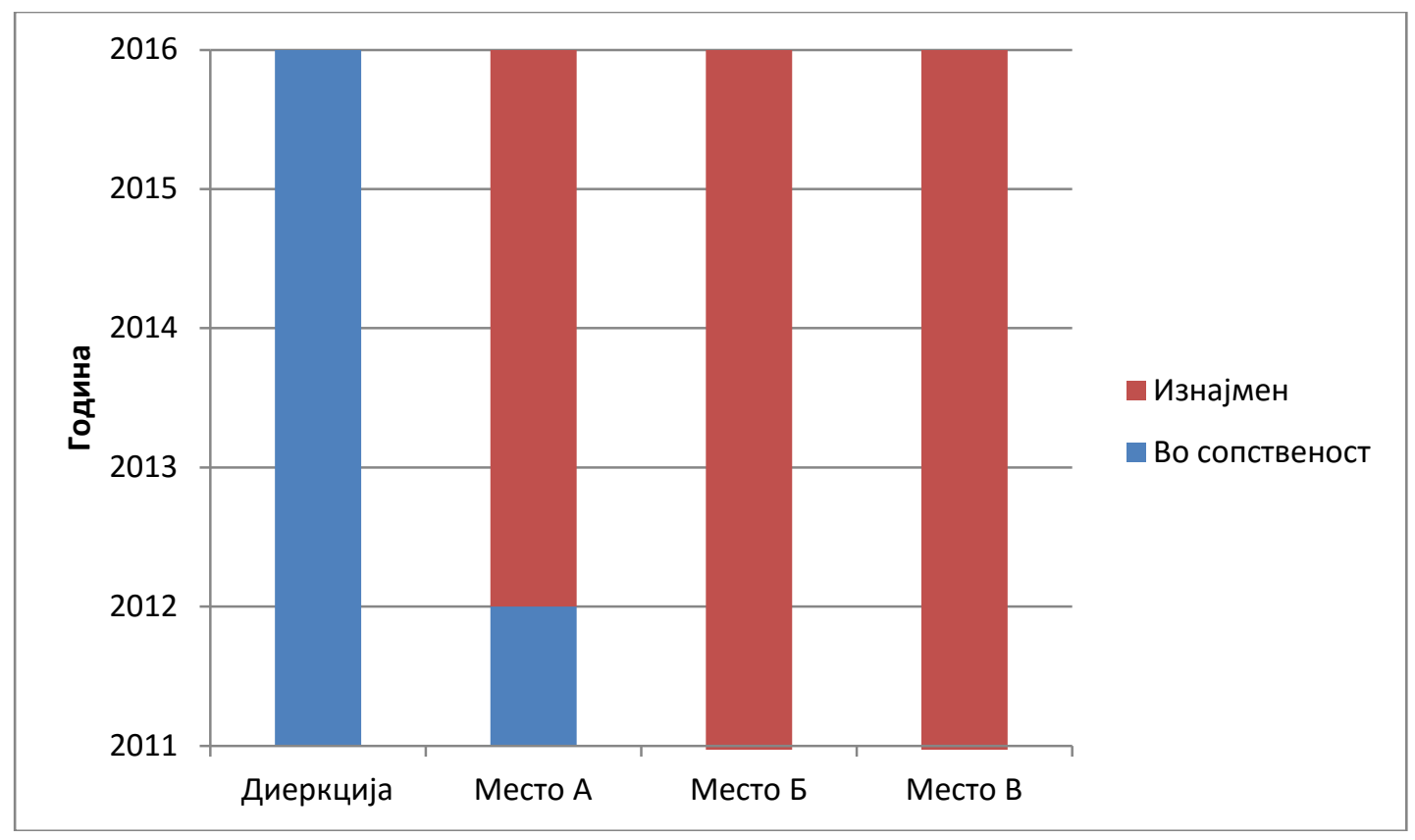

Графикон 1.Сопственост на секој објект одделно во следните неколку години

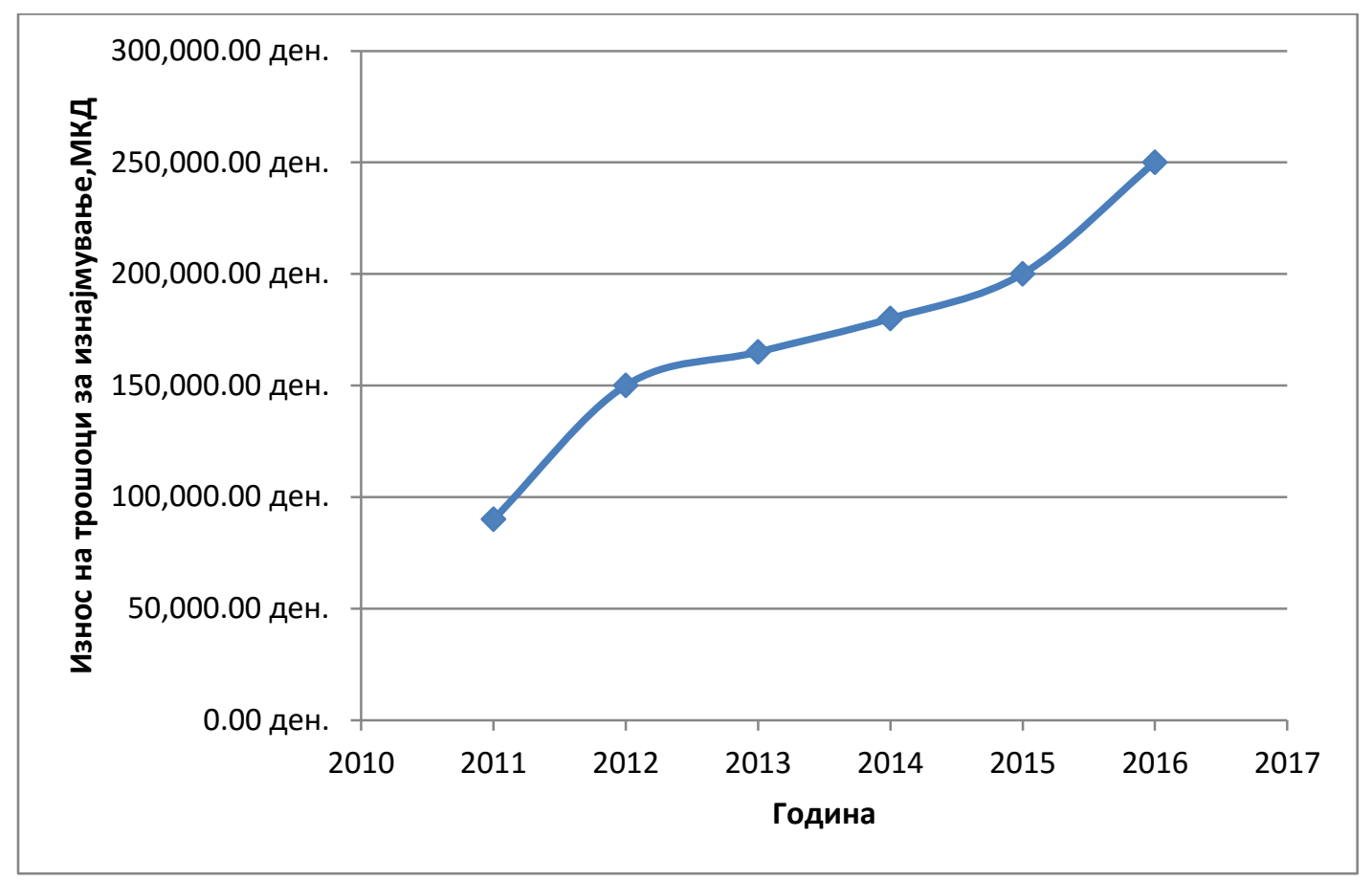

Графикон 2. Движење на трошоците за изнајмување 
Анализа на концептите на организација и опремување со мебел кај канцелариските простори магистерски труд Зејнелабедин Азири

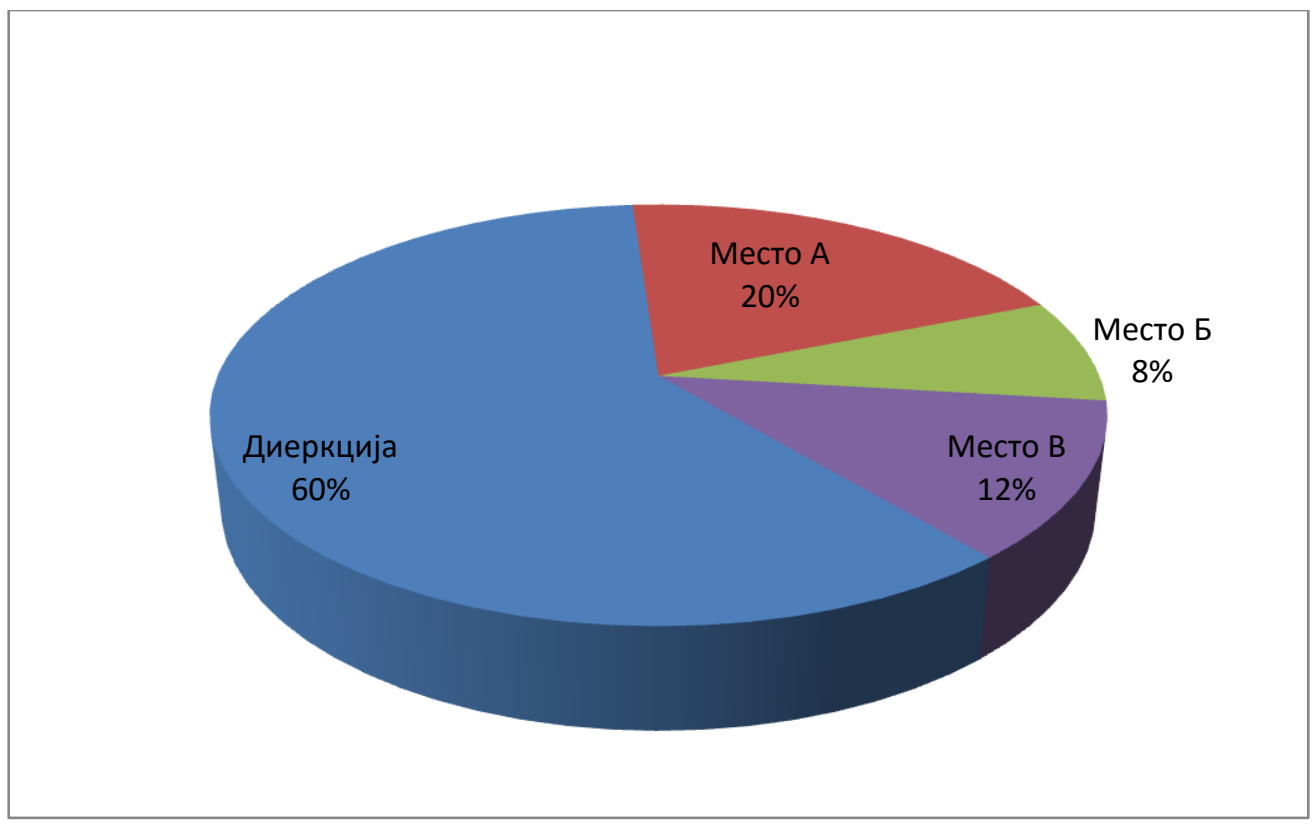

Графикон 3. Удел на компонентите од ентериерот во севкупниот корисен простор во објектот

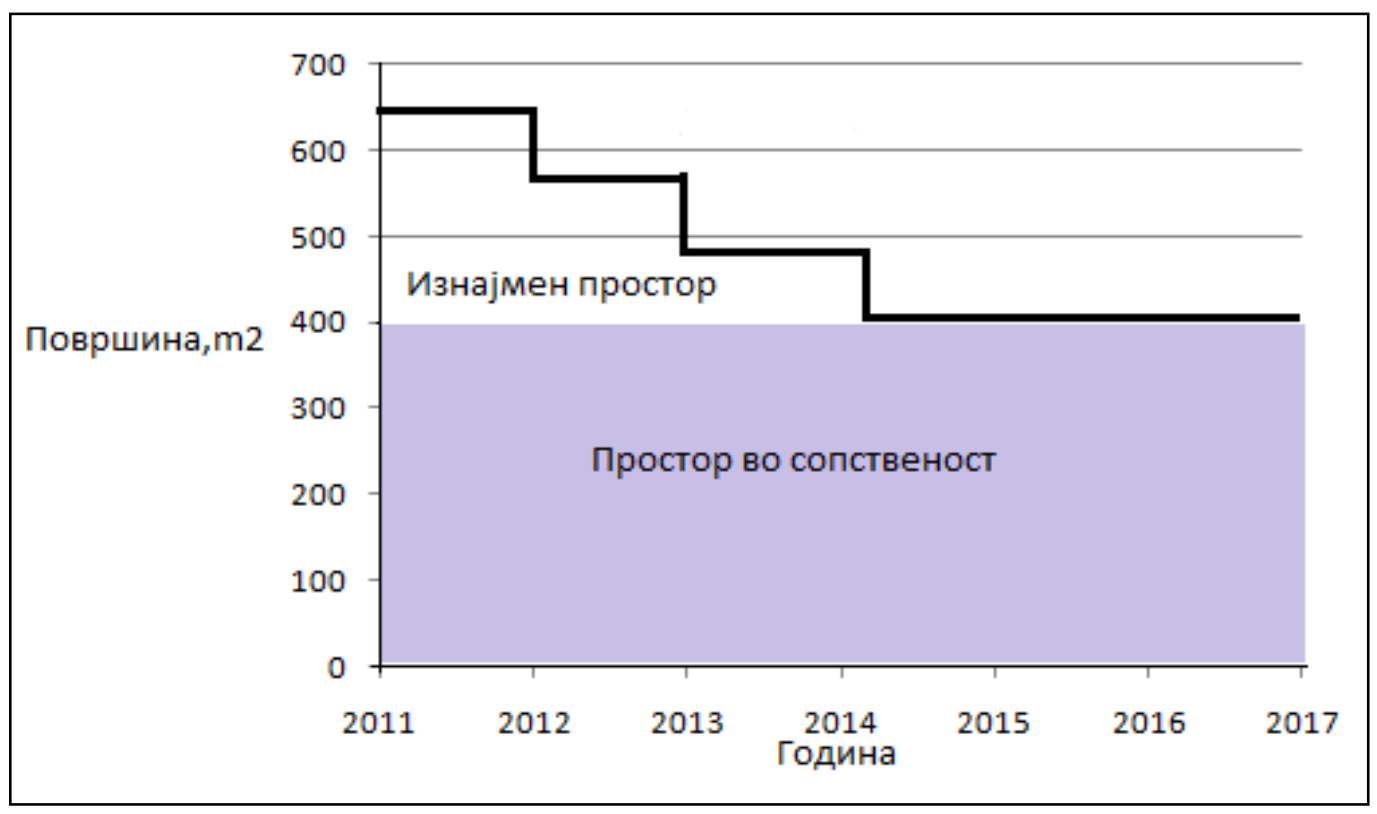

Графикон 4. Одделно прикажување на просторот во сопственост и изнајмениот простор 


\section{Стандарди за планирање и мебел}

Стандардите за проектирање и опремување на просторот со мебелпретставуваат општо прифатени димензии на различни видови на канцеларијски мебел и останата опрема. Овие стандарди претставуваат основа или мерка за планирање со цел развој на вкупната површина потребна за друштвот. ${ }^{6}$ Како пример, подолу се претставени стандарди за сала за состаноци во зависност од тоа за колку лица истата е наменета.

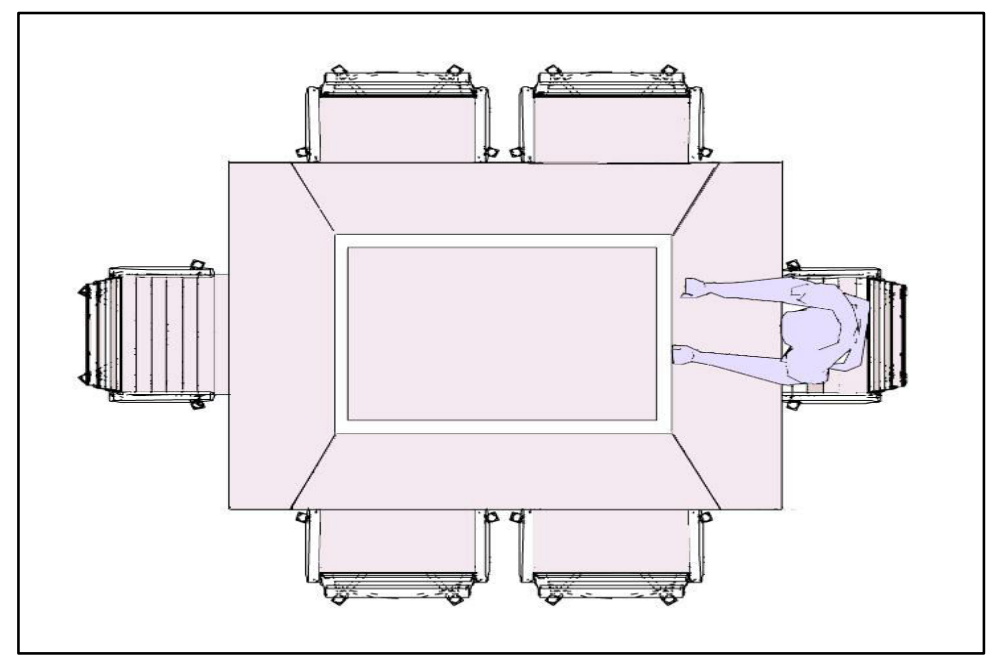

Цртеж.1 Сала за состаноци за шест лица7, 17 м²

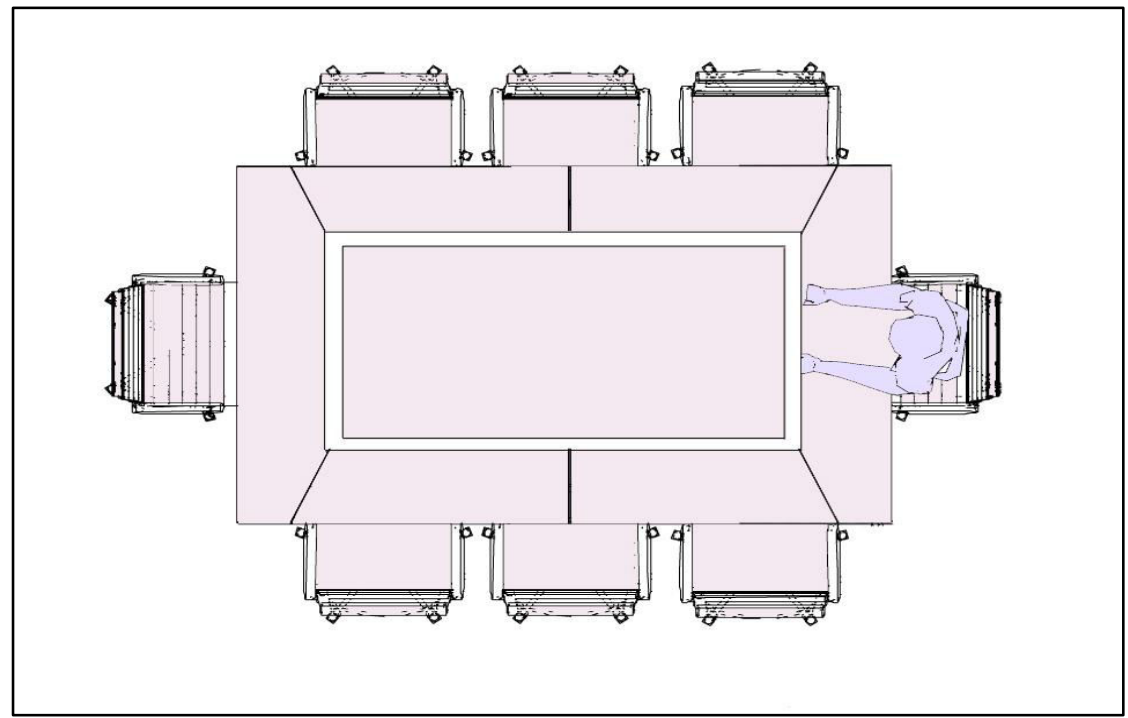

Цртеж.2 Сала за состаноци за осум лица ${ }^{8},{20 M^{2}}^{2}$

${ }^{6}$ Нојферт E., Whitney Library of Design, New York, 1978.cт 193

7,8, Нојферт E., Whitney Library of Design, New York, 1978.ст 193 

магистерски труд Зејнелабедин Азири

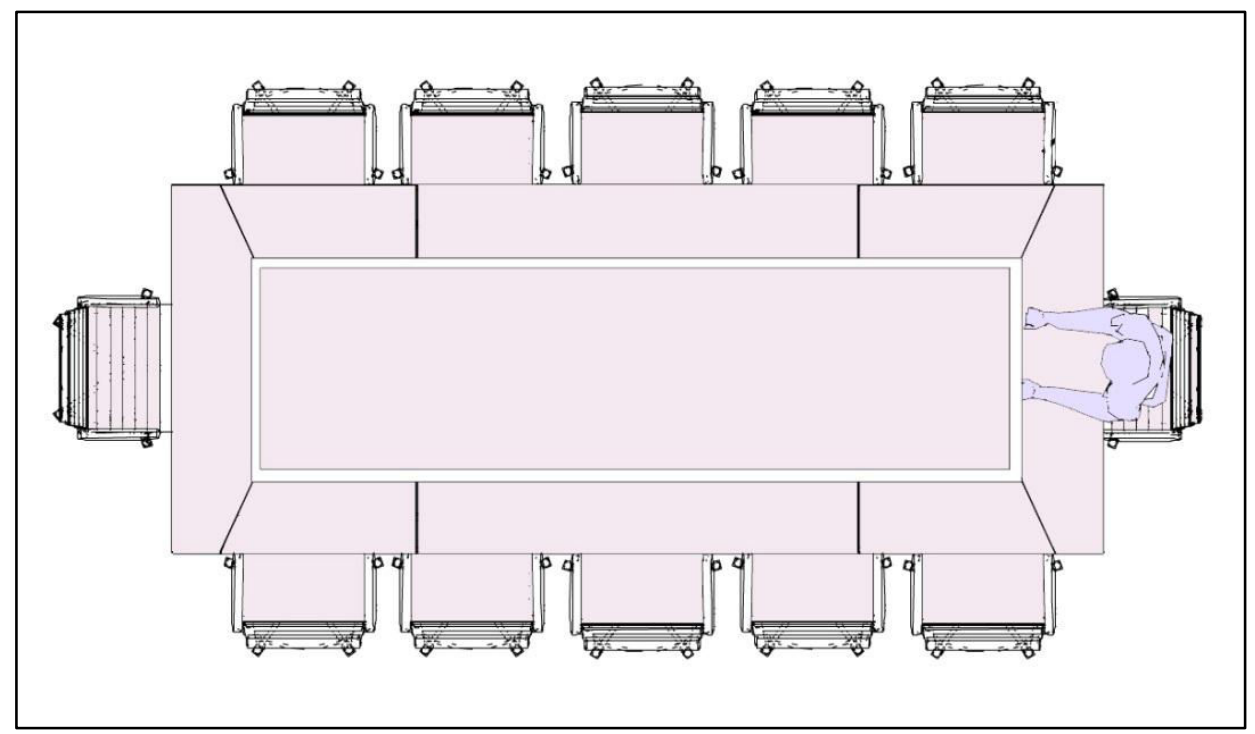

Цртеж.3 Сала за состаноци за дванаесет лица9, 24м²

Понатаму, претставени се стандарди за големина на канцелариски простори во зависност од бројот на корисници и намената.

Цртеж.4 Канцелариски простор ${ }^{10}, 2.2 \mathrm{M}^{2}$

1. Работна Површина, 2. Работен стол, 3. Плакари

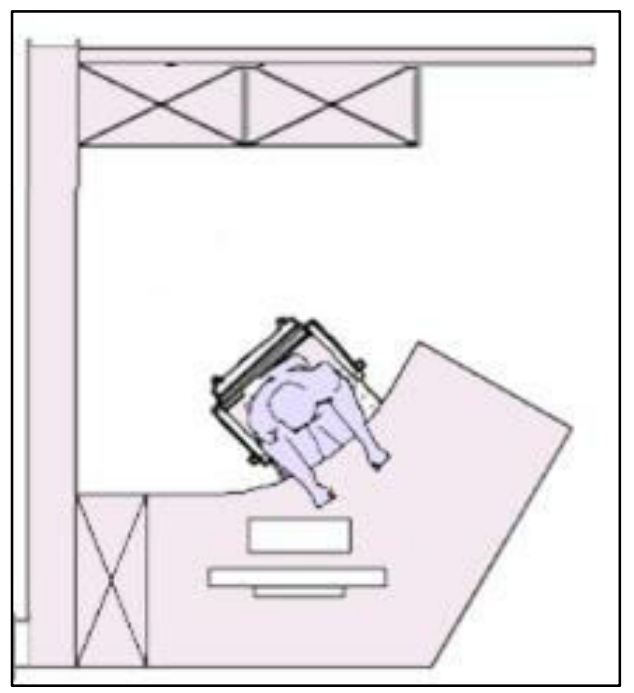

${ }^{9}$ Hojферт E., Whitney Library of Design, New York, 1978.cт 193

${ }^{10}$ Нојферт E., Whitney Library of Design, New York, 1978.cт 193 


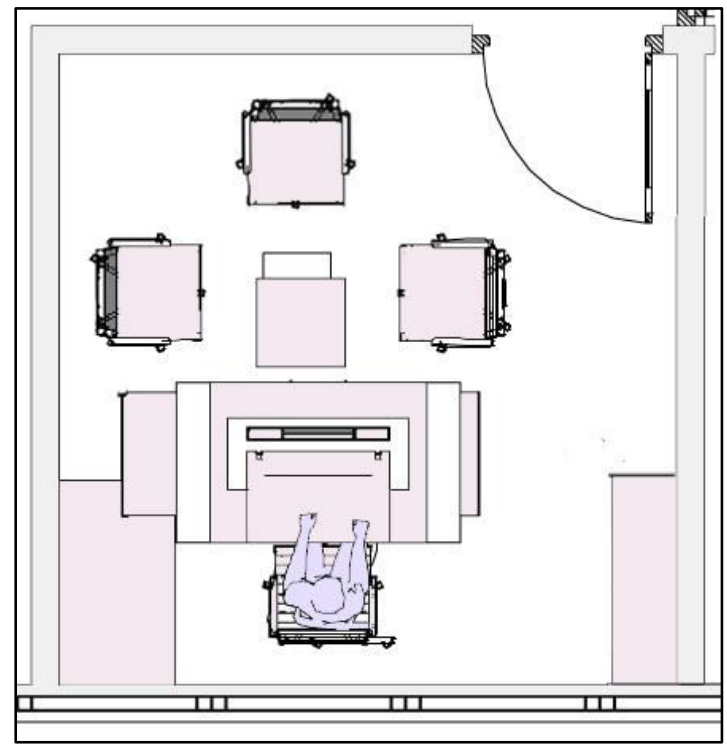

Цртеж.5Канцелариски простор ${ }^{11}, 14 \mathrm{M}^{2}$ 1. Работна Површина, 2. Работен стол,3. Плакари, 4.Маса загости,5. Столици за гости

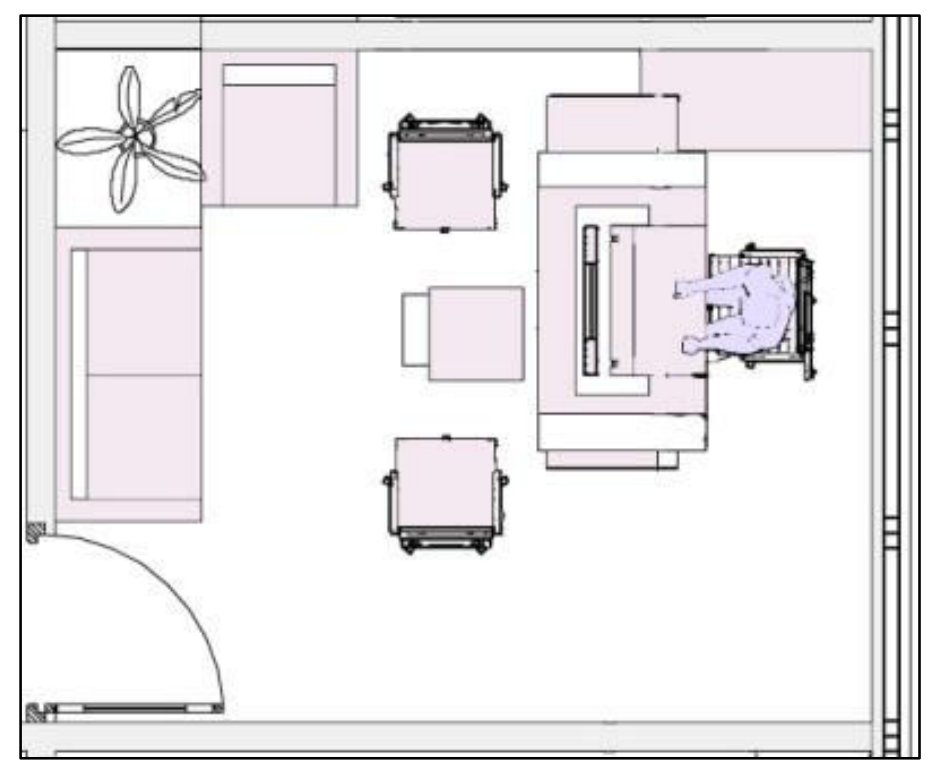

Цртеж.6Канцелариски простор ${ }^{12}, 16.7 \mathrm{M}^{2}$ 1.Работна Површина 2.Работен стол 3.Плакари 4.Маса за гости 5.Столици за гости

${ }^{11}$ Нојферт E., Whitney Library of Design, New York, 1978

${ }^{12}$ Hojферт E., Whitney Library of Design, New York, 1978 


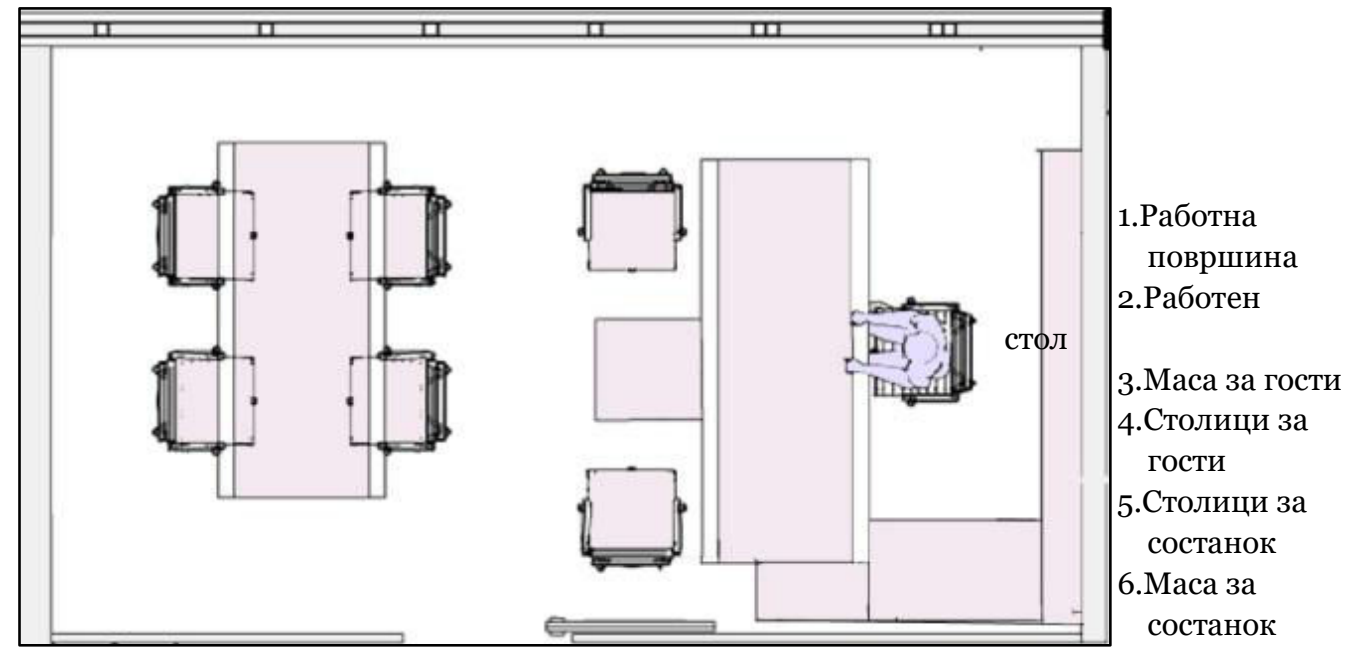

Цртеж.7Канцелариски простор ${ }^{13}$, 21M $^{2}$

\section{Стандарди за планирање на користењето на кацеларискиот простор низ времето}

Тековните политики за недвижност на организацијата имаат влијание врз подготовката на стандардите за планирање и податоците за елементите на мебел кој што се користат при процесот на планирање. Тие исто така влијаат врз достапните алтернативи за постигнување на идните потреби. На пример, доколку организацијата има нова политика за недвижности каде што повеќе се наложува користење на простории под наем ќе има влијание врз распространетоста на просториите и последователно исто така влијае врз стратешкиот план на просториите во однос на број, вид и тајмингот на достапноста на просторот. ${ }^{14}$

Спроведената евалуација на тековната ситуација на организацијата обезбедува основа за следниот чекор во процесот на стратешко планирање, идентификување на потребите.

\section{Идентификување на потребите}

Целта на идентификување на потребите е да се утврди вкупниот простор потребен на друштвото за тековните потреби и за во иднина. Во овој дел се собираат квантитативните и квалитативните потреби преку разни активности (лични интервјуа,

\footnotetext{
${ }^{13}$ Нојферт E., Whitney Library of Design, New York, 1978

${ }^{14}$ Office Interior Design Guide, Rayfield K. Julie
} 
прашалници и сл.). ${ }^{15}$

Во овој дел се идентификува само потребниот волумен на просторот и карактеристиките кои би биле под влијание на архитектурата на објектот или системите за поддршка на зградата (механички и електрични системи). На пример, доколку станува збор за дизајнирање на канцеларија, се идентификува само потреба од една соба (деталите за бројот и видот на плакарите и останатата опрема се исклучени) со специфично идентификување за тоа дали е потребно зацврстување на подот со соодветен материјал (на пример, челик) за да го издржи дополнителниот товар.

Потребната површина потребна за сместување на организацијата со цел да ги достигне тековните и идните потреби се смета како квантитативна потреба. Овие потреби ги вклучуваат сите работни простории и останати простории (амфитеатар, кафетерии, ходници и сл.). Тековните бројки за организацијата може да се добијат од постојниот број на вработени и истражувањата на постојниот простор во употреба. Предвидувањата за потребите на простор за работа и други активности вообичаено се прават преку проекции за три до пет години. Изворот на проекциите претставуваат прашалници и лични интервјуа со клучните управители и одговорните лица на дирекции или сектори. ${ }^{16}$

Подолу претставени се графикони, Графикон 5 и Графикон6, во однос на тоа како би требало да биде претставена анализата за потребниот простор. Во овие два графикони претставен е предлог за тоа како би требало да биде презентирана спроведената анализа за потребниот простор според видот на просторот и корисникот.

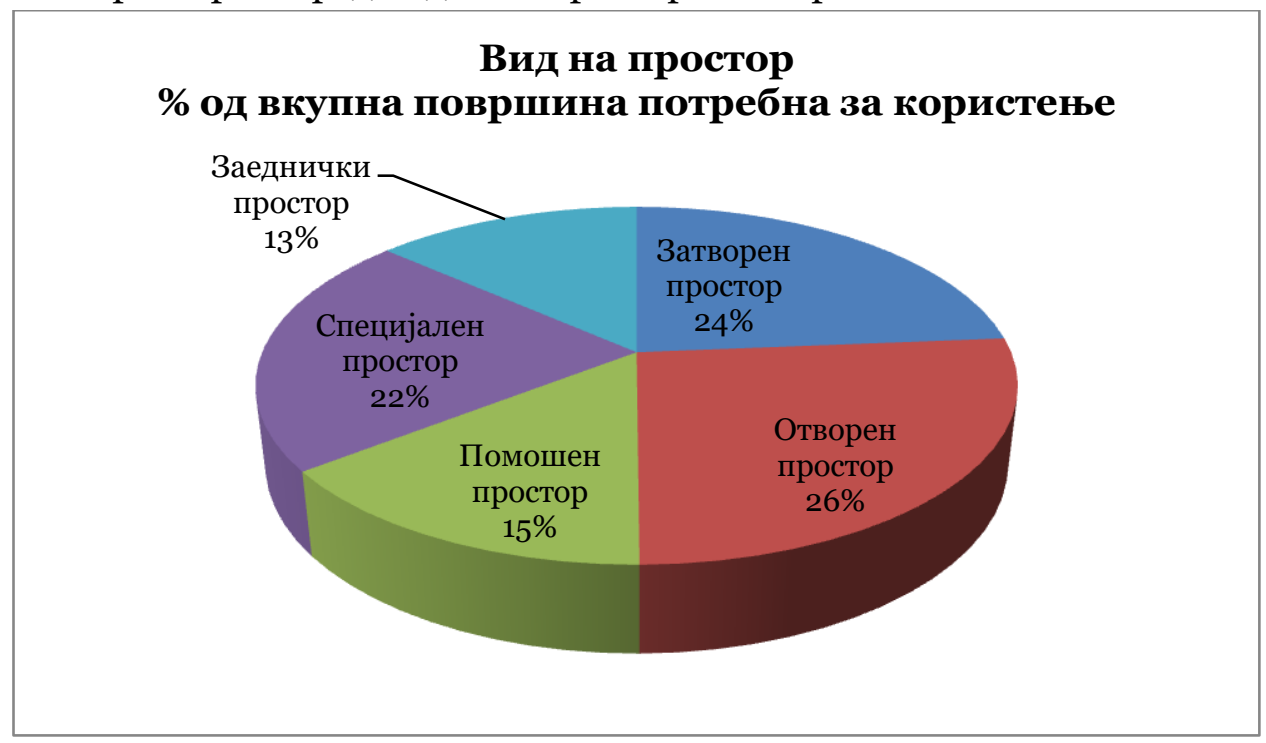

Графикон 5. Анализа на потребната површина според вид на простор

Во Графикон5 под помошен простор се подразбира оној простор кој е потребен да се овозможи за оние личности кои се инволвирани при изградба на објект. Во истиот графикон под специјален простор влегуваат просториите како кафетерија, рецепција (приемен пулт и сл.), простор за обука и др. Додека под заеднички простор вклучени се просториите како конференциска сала, простор за скали и сл.

\footnotetext{
${ }^{15}$ Office Interior Design Guide, Rayfield K. Julie,

${ }^{16}$ Office Interior Design Guide, Rayfield K. Julie,
} 

магистерски труд Зејнелабедин Азири

\section{Дирекција \% од вкупна потребна површина}

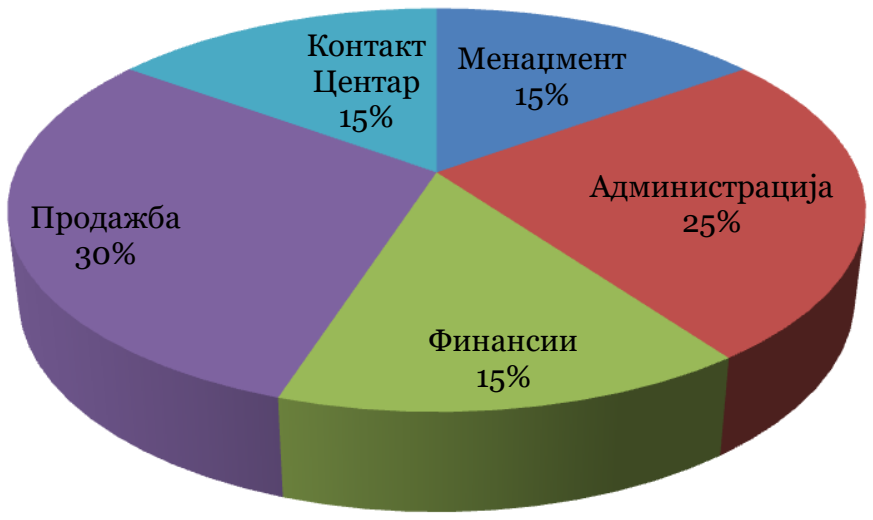

Графикон 6. Анализа на потребна површина според дирекција

Во следните два графикони, Графикон 7 и Графикон 8 претставена е анализата на потребната површина кај новинската агенција.

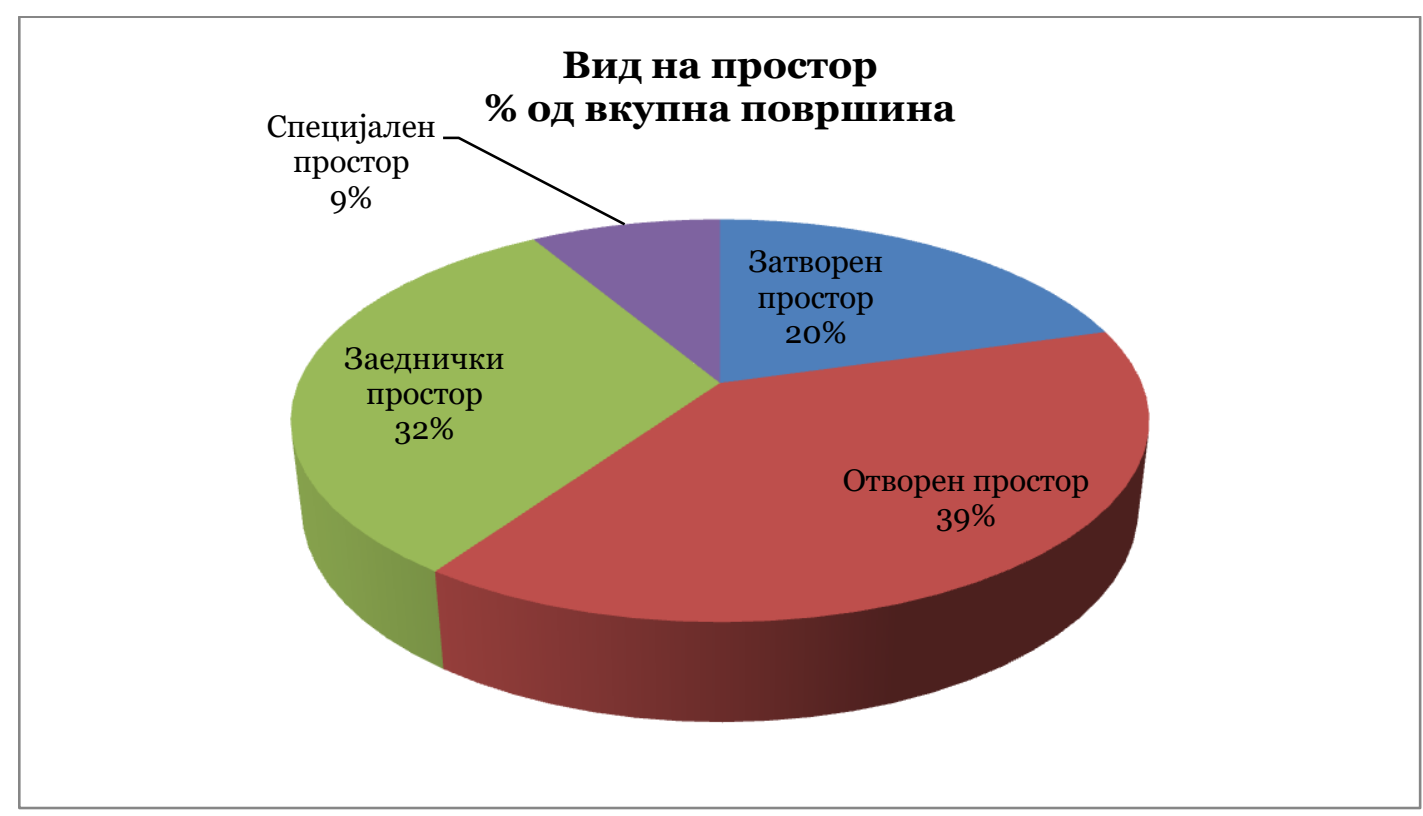

Графикон 7. Анализа на површина според вид на простор кај новинската агенција

Во Графикон7 под специјален простор влегуваат кујната и тоалетот додека под заеднички простор вклучени се салата за состаноци и просторот за одмор како и просторот предвиден за комуникација во објектот. 


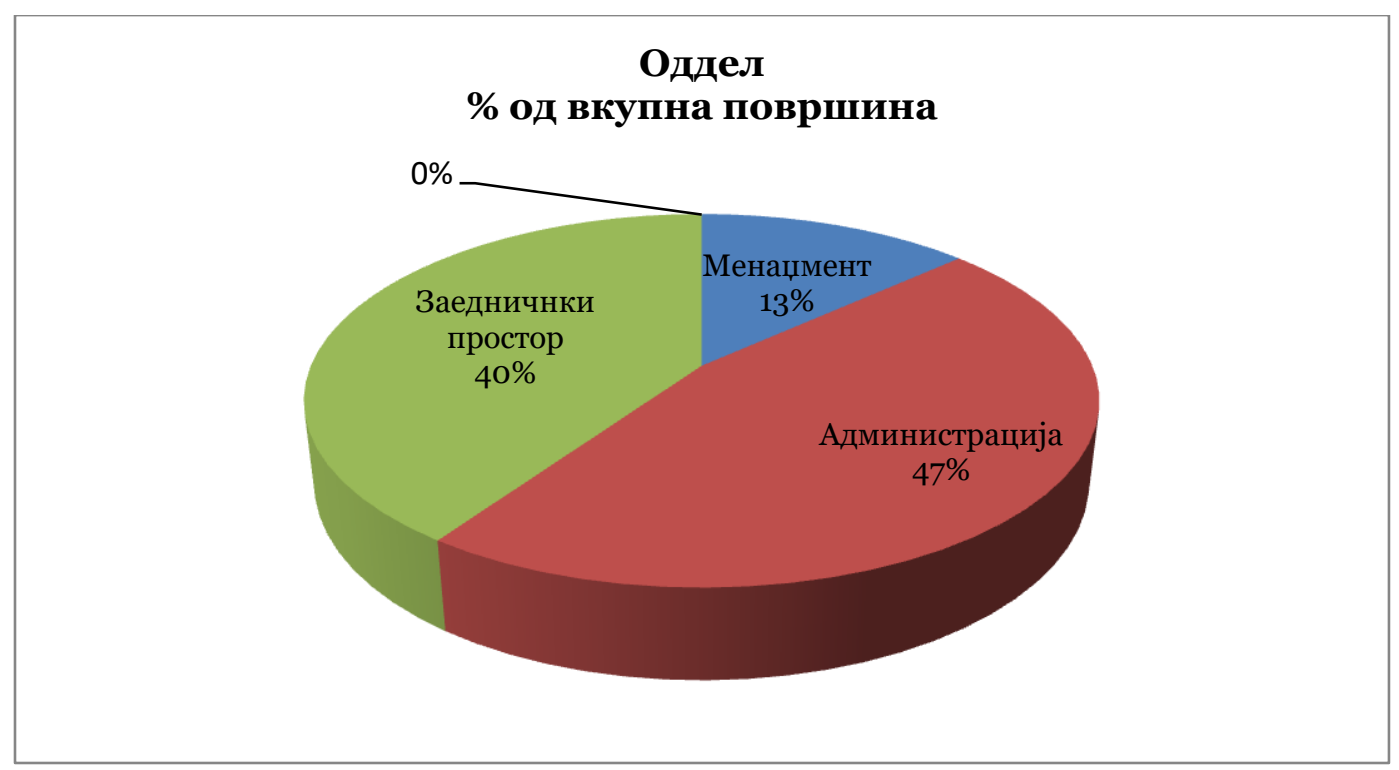

Графикон 8. Анализа на површина според оддел кај новинската агенција

Во Графикон8 под менаџмент вклучен е само генералниот уредник додека под администрација вклучени се секретарот, лицето за односи со јавност како и новинарите. Останатиот дел од вкупната површина вклучен е под заеднички простор.

Во следните два графикони, Графикон9 и Графикон1о, претставена е анализа на потребната површина кај правната канцеларија.

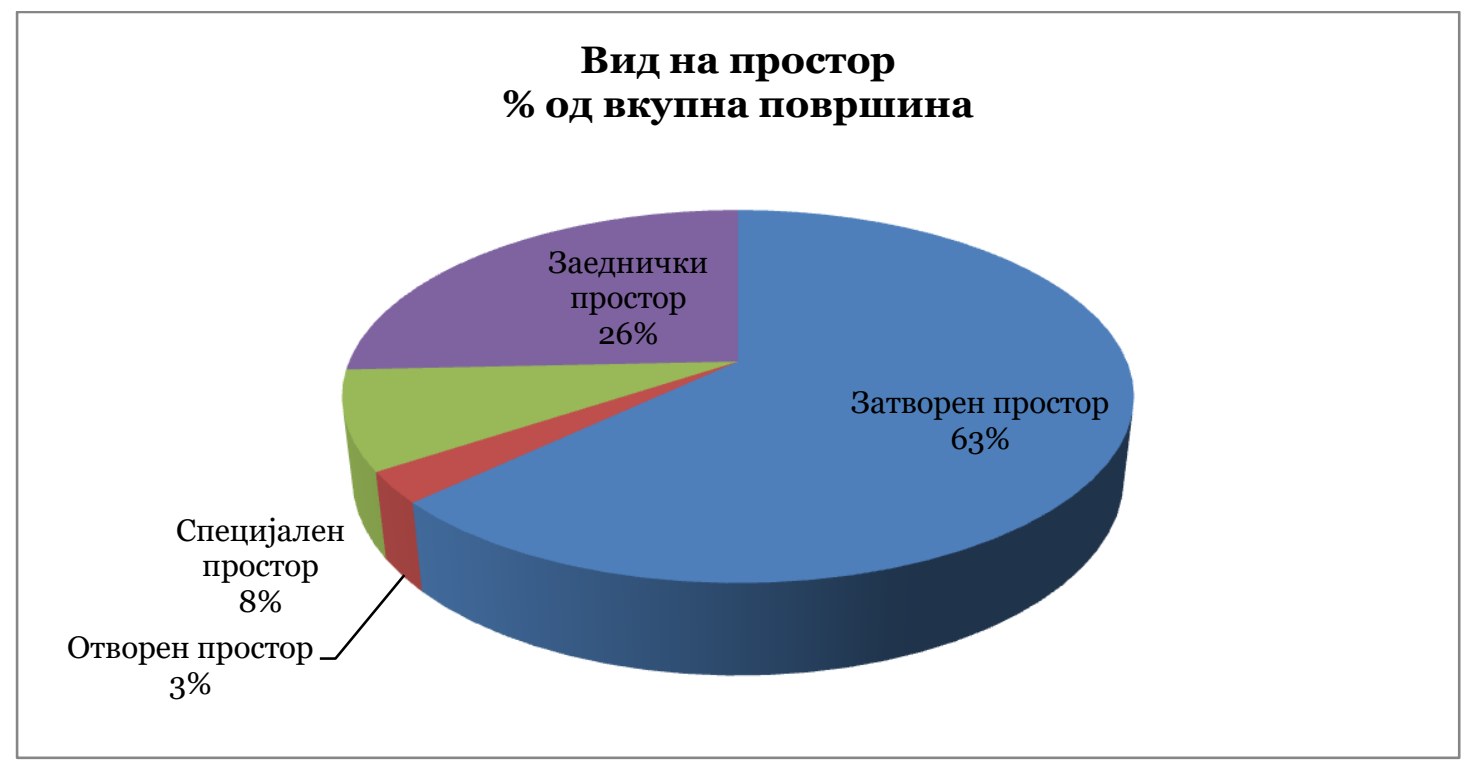

Графикон 9. Анализа на површина според вид на простор кај правната канцеларија

Во Графикон9 под специјален простор влегуваат кујната и тоалетот додека под заеднички простор вклучени се просторот за чекање како и просторот оставен за движење. 


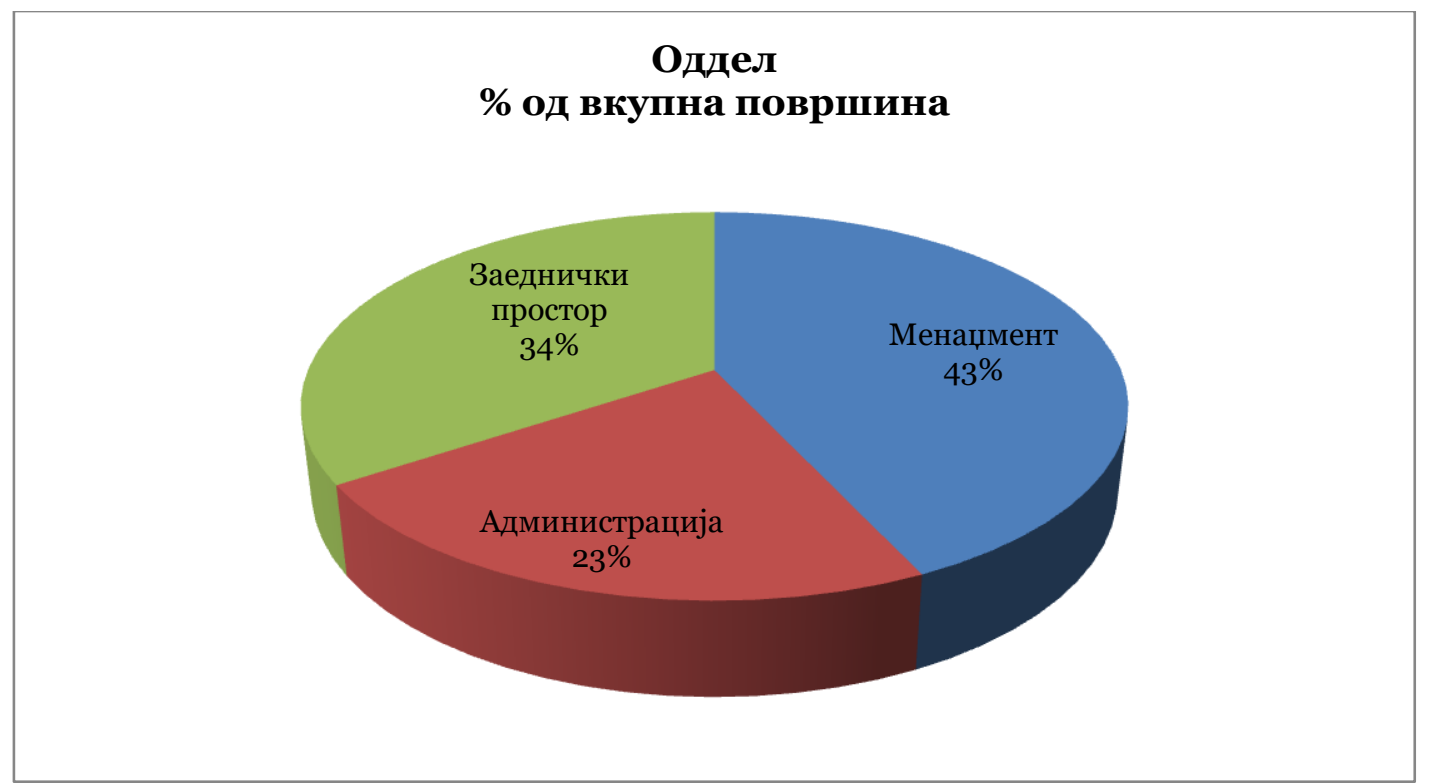

Графикон 10. Анализа на површина според оддел кај правната канцеларија

Во Графикон 10, под менаџмент вклучени се само адвокатите додека под администрација вклучени се нотарот со својот помошник како и секретарот. Останатиот дел од вкупната површина вклучен е под заеднички простор.

Откако ќе се пресмета големината на потребната површина за секој дел/дирекција одделно потребно е нивниот збир да се помножи со мултипликатор на циркулација во зависност од тоа колку изнесува процентот на површина потребен за движење/циркулација помеѓу дирекциите/канцелариите. Пример за тоа како треба да се пресмета овој мултипликатор е даден подолу. Доколку потребната површина изнесува (збир од сите диркеции) изнесува 100 м2 и доколку потребниот процент за циркулација изнесува 40\% во тој случај мултипликаторот за циркулација се пресметува на следниов начин,

$$
\frac{40 \%}{100 \%-40 \%}=0,67
$$

Следно, потребно е да се пресмета количеството површина потребна за циркулација,

$$
100 \mathrm{M2} * 0,67=67 \mathrm{M2}
$$

На тој начин се добива резултатот, односно вкупната потребна површина изнесува 167 м2 (збир од сите дирекции плус простор за циркулација).

Целта на идентификување на квалитативните потреби на просторот е да се добијат доволни информации за подобро дефинирање на критериумите за издржливост и утилитарност на објектот така што просторот ќе ги задоволи потребите на корисникот.

Квалитативните потреби на просторот кои се земаат во предвид се сите карактеристики кои влијаат на ентериерот и на архитектонската структура на просторот анализирана од аспект на ентериер и интервенциите кои се подразбираат со проект за ентериер. ${ }^{17}$

\footnotetext{
${ }^{17}$ Office Interior Design Guide, Rayfield K. Julie
} 


\section{Анализа на добиените податоци}

По добивање на потребната слика за тоа кои се барањата на организацијата, се подготвува анализа за тоа колку овие потреби се во согласност со моментното ниво на развој во одредениот сектор. Исто така, се мери и сензитивноста на овие податоци преку мерење на ризикот поврзан со нивната точност. Причината поради која се изведува оваа анализа е да се тестираат направените препоставки и валидноста на информациите и да се испита потенцијалниот ризик поврзан со секое алтернативно решение. Како резултат на оваа анализа, ќе се овозможи соодветна флексибилност во планот со цел приспособување кон секој можен ризик или непредвидена работа. ${ }^{18}$

Анализата може да се спроведе преку три чекори, како што е наведено подолу, 1.Првиот чекор во анализата е да се прегледаат сите трендови во организацијата и индустријата со цел да се утврди дали претходно проектираните потреби на организацијата се соодветни со овие трендови.

2.Вториот чекор во анализата е да се утврди сензитивноста на добиените резултати. Со цел да се постигне ова, личноста мора да ги идентификува сите фактори кои што влијаат врз валидноста на информациите и одлуките донесени при процесот на стратешкото планирање.

Факторите може да бидат внатрешни или надворешни во однос на организацијата.

- Внатрешните фактори вклучуваат:

- упатства на менаџментот

- мисијата на организацијата

- финансиската структура

- употреба на технологија

- корпоративна култура

- Надворешните фактори вклучуваат:

- општи економски услови

- промени на пазарот

- правен систем

- геополитичка клима

3. Третиот чекор во анализата,откако сите фактори се евидентирани,е да се предвиди потенцијален ризик на секој фактор. На пример, личноста има предвидено дека информацијата која ја добил при процесот на развој на потребите е точна. Во овој чекор се пресметува колку е можноста оваа информација да е неточна и кој е соодветниот потенцијален ризик. Ризикот и одлуките донесени врз основа на предвидливите ризици се земаат во предвид во следното ниво на стратешкото планирање, развој на дефиниција на производот; како и во последниот чекор од стратешкото планирање, развој на алтернативи и крајни предлози.

\footnotetext{
${ }^{18}$ Office Interior Design Guide, Rayfield K. Julie, стр.12 и 13
} 
Анализа на концептите на организација и опремување со мебел кај канцелариските простори

магистерски труд Зејнелабедин Азири

\section{Дефиниција на производ}

Во овој дел се дефинираат карактеристики на просторот како производ добиен со проектот во процесот на уредување, кои се потребни за да ги задоволат долгорочните потреби на организацијата (дефинирани во претходното ниво-развој на потребите). Во претходниот дел, развој на потребите, се предвидуваше големината на потребниот простор, додека во овој дел би требало да се утврдат карактеристиките на потребниот простор како што се следниве: Потребен простор во секој иден, нареденгодишен период (како и тоа да се предвиди дали ќе има зголемување или намалување);19

-Вид на потребен простор, на пример, простор за работа, простор за движење, кафетерија или слично,колкав ебројот на секој вид простор одделно и нивото на квалитет;

-Конфигурација на простор, дефинирање на оптимално потребната големина на основа, конфигурација на структурата на објектот, товар од консструкцијата и од елементите на ентериерот врз меѓукатната конструкција; конструктивниот систем на носивост на објектот (скелетен систем, подетални специфики околу истиот и сл.);

- Потреби за инфраструктура како што се: вертикален транспорт (лифтови), греење, вентилација и климатизација на објектот, системи за пренос на струја и податоци.

Нивото на деталност требада биде доволно за да даде доволно насокиво процесот надизајнирање.Флексибилноста е клучна за успешно стратешко планирање на просторите поради тоа истото треба да биде вклучено во дефиницијата на производот.

Прашањето во однос на тоа дали е подобар отворен или затворен план на основата со решението, не се однесува на коректност, туку на два различни пристапи кон планирањето на канцелариски простор. Секој од овие пристапи има придобивки и недостатоци. На крајот одлуката на организацијата треба да биде донесена врз основа на пристапот кој најдобро ги задоволува целите на компанијата. Вообичаено, компанијата која има потреба од значителна флексибилност при планирањето користи отворен план.

Отворениот план за просторот може ја зголеми ефикасноста на потенцијалното планирање, да го намали трошокот на животен век (на просторот и на мебелот) при набавување на нов канцелариски простор и да овозможи одговор кој е брз и ефтин при зголемени почести промени во компанијата и нејзините активности. Кај компаниите со мала потреба од флексибилност и голема потреба од приватност обично се применува затворен план.

- Следниве критериуми може да се користат како основа за проценка на двата приоди:

- ористење на просторот

- Флексибилност при планирање

- Трошок

- Комуникација помеѓу вработените

- Флексибилност на канцелариската технологија

- Визуелна приватност

- Визуелна експанзивност

- Звучна приватност

- Сигурност

${ }^{19}$ Office Interior Design Guide, Rayfield K. Julie, стр.14 и 15 


\section{Утврдување и евалуација на алтернативи}

Во стратешкото планирање вообичаено повеќе различни опции/алтернативи се валидни за задоволување на идентификуваната дефиниција на производот, односно за усогласување со карактеристиките на просторот утврдени во претходниот дел-дефиниција на производ. Во овој дел, потребно е да се анализираат тие алтернативи.

Со цел да се утврдат алтернативите, потребно е да се земат во предвид претходно добиените резултати од претходните нивоа (дефиниција на производ, инвентар на мебел, политики на недвижности, потребите на организацијата). Секоја алтернатива содржи соодветен распоред и износ на трошоци. ${ }^{20}$

- Критериумите со кои што се прави евалуација на опциите треба да вклучуваат:

-Вкупна вредност на избраната алтернатива

- Колку добро алтернативата што ќе се одбере, ќе се вклопи со мисијата на организацијата?

- Колку добро алтернативата што ќе се одбере е во согласност со потребите на организацијата?

Големината на влијание на секоја од овие критериуми зависи од тоа колку тие се важни за организацијата.На пример, доколку компанијата има потреба од затворен план на просторот, алтернативно може да се предвидат преградни sидови од гипс - картон плочи.Додека како втора алтернатива преградите би можеле да бидат изведени од полупроsирен или прозирен материјал (како на пример стакло третирано со киселина, гравирано или пак полесни исполниод плексиглас во профили од метал или дрво.Во зависност од тоа колку компанијата сака визуелна приватност на дирекцијата, но исто така и звучна ќе се одбере една од овие алтернативи. Но исто така, во одлуката би влијаела и трошокот на секоја опција одделно.

\footnotetext{
${ }^{20}$ Office Interior Design Guide, Rayfield K. Julie, стр. 19 и 96
} 


\section{2. Организација на проектот}

Наредната фаза во процесот на стратешко планирање е имплементација на проектот. Поимот проект за ентериерот ги подразбира сите активности на планирање, собирање податоци за претпријатието и вработените, анализа на принципите на работа на претпријатието, обмислување и реализација на концептот на уредување на просторот со јазикот на архитектурата и со принципите на светските стандарди за уредување. (пр. Нојферт и сл.)

Стратешкото планирање на просторот во една организација може да воспостави насока за тоа што треба да се направи и задоволи со цел да се работи во правец на долгорочните потреби на организацијата и истите да бидат задоволени.Деталите на пред изработката на главниот проект,и пред изведбениот проект, се однесуваат на фазата наречена - организација на проектот.

Планирањето на проектот би требало да биде во склоп со стратешкиот план на просторот на организацијата. Ова е потребно за да се утврди дали потребите на организацијата се задоволени. Поради тоа пред започнување на планирање на некој проект и негово имплементирање потребно е да се подготви стратешки план на просторот на организацијата. За таа цел најдобро би било веднаш по фазата стратешко планирање на проектот да следува - фаза на организирање.

Фазата на организација на проектот ги дефинира потребите на проектот и неговите цели, учесниците во проектот, нивните улоги и одговорности и дефинира процес на донесување на одлука. Организирањето на проектот треба да се превземе во следниве чекори:

- Развој на тим од вработените во организацијата

- Развој на процес на носење на одлука

- Дефинирање на потребите и целите на проектот

- Собирање на информации релевантни на организацијата и проектот

- Избор на консултанти

- Развој на прелиминарен распоред на проектот и буџет

Во понатамошното излагање во трудот, накусо е објаснетсекој дел од оваа фаза посебно.

\section{1 Дефинирање на потребите и целите на проектот}

Внатрешниот тим треба да содржи група од професионалци способни да го дефинираат проектот и да управуваат со процесот. ${ }^{21}$ Во зависност од специфичноста на проектот и достапната експертиза се одредува бројот на членови во тимот, којби требало да ги вклучи особено оние лица, кои имаат поголеми сознанија во однос на одредениот проект. Во процесот на дефинирање на целите на проектот корисни се и оние соработници кои иако немаат знаења од областа на проектот, сепак може да бидат засегнати од примената на проектот. На пример, доколку станува збор за промена на софтверот засметководство на една компанија покрај финансискиот менаџер и сметководителот на компанијата потребно е да се вклучи и магационерот или друго одредено лице кое би можело во одреден случај да го користи софтверот. Со вклучувањето

\footnotetext{
${ }^{21}$ Office Interior Design Guide, Rayfield K. Julie, стр.21, 22и 23
} 
Анализа на концептите на организација и опремување со мебел кај канцелариските простори магистерски труд Зејнелабедин Азири

на претставници од различни групи се овозможува добивање на точни информации и понатаму развој на соодветни решенија.

Целта во овој дел е креирање на едноставен и ефикасен процес за донесување на одлука кој ги идентификува личностите што донесуваат одлука и средствата кои помагаат да се донесе одлуката. ${ }^{22}$

Внатрешниот тим исто така може да претставува тим кој носи одлука во зависност од нивната екпсертиза доколку се работи за поедноставен проект. Во случај на покомпликуван проект овој тим може да ги носи само дневните одлуки за што ќе го известува управниот одбор. Процедурите за донесување на одлука треба да ги дефинираат одговорностите на секоја група (кои предмети се предмет на нивна одлука) и во кои делови за време на проектотсе потребни нивните одлуки.

Откако процесот за донесување на одлука е подготвен тимот може да развие дефиниција на проектот која може да се користи во правењето на проектниот тим од професионални консултанти и развој на стратегија за одлучување на потребите.

- Дефиницијата треба да го вклучува следново:

-Потреба од проектот

-Причина за потребата

-Цели на проектот

-Параметри за решение

\section{2Собирање на информации значајни за компанијата и проектот}

Собирањето на информации кои се однесуваат на компанијата и проектот е важно со цел да се изберат консултантите и нивно насочување кон целите на проектот.

- Информациите кои што ќе се обезбедат потребно е да содржат:

-Краток преглед на компанијата (основање, дејност, резултати сл.)

-Производи и/или услуги на компанијата

-Цели на компанијата

-Организациона структура и структура на вработените во компанијата

-Планови од просториите кои што компанијата тековно ги користи и кои што би можеле да бидат афектирани од страна на проектот

-Стандарди за планирање на тековните простории

-Тековни податоци за програмирање

-Предности и недостатоци на тековните простории

-Информации за одржување и/или поправка на просторите кои што се под влијание на проектот

Тимот консултанти би требало да се состои од личности експерти во полето на менаџирање, техника и креативност кои се потребни од почетокот до комплетирање на проектот и кои имаат искуство во одредени полиња значајни за проектот (недвижности, проектно менаџирање, дизајн, внатрешна архитектура и сл.)

Доколку се организира повеќе сложен тим истиот најчесто бара и дополнителна координација и управување, но затоа пак има предности од користење на професионалец во секоја област потребна за проектот.

\footnotetext{
${ }^{22}$ Office Interior Design Guide, Rayfield K. Julie, стр.23,25 и 26
} 


\section{3Развој на прелиминарен распоред на проектот и буџет}

Распоредот на проектот го дефинира редоследот на активностите кои треба да се спроведат со цел да се комплетира проектот успешно во рамки на планираните цели. Прелиминарниот распоред треба да биде подготвен следејќ ги следниве чекори:

- Дефинирање на краен датум на комплетирање на проектот

- Дефинирање и правење на листа на сите значајни активности поврзани со проектот

- Дефинирање на временски периоди за комплетирање на секоја активност одделно

- Дефинирање на клучни датуми за донесување на одлуки

- Печатење, распределување и следење на подготвениот распоред

Без разлика на нивото на деталност со кој е подготвен распоредот, од голема важност е да се дефинираат клучни датуми во соодветни делови на распоредот. На овој начин, сите поврзани лица ќе бидат известени за датумите во кои треба да се дадат одобренија или да се донесат одлуки со цел проектот да се спроведува според планираниот тек.

Креирањето на буџет во оваа фаза би овозможило точен и реален преглед на финансиските параметри кои би имале влијаније врз спроведувањето на проектот. ${ }^{23}$ Прелиминарниот буџет треба да биде подготвен следејќи ги следниве чекори:

- Опис на градежните зафати

- Дефинирање на трошокот поврзан со градежните зафати

- Одредување на потребниот мебел и бројот на секое парче одделно

Во делот за опис на градежните зафати потребно е да се дефинира што поточно ќе биде предемт на градежни зафати. На пример, реконструкција на површина од 200 м2 намената за канцелариски простор.

Со цел да се дефинира трошокот поврзан со градежните зафати најдобро е да се определи трошокот кој што се однесува на метар квадратен за секој вид на простор одделно (канцелариски простор, кујна и сл.).

Во делот на одредување на потребниот мебел и бројот на секое потребно парче (столица, маса, плакар и сл.) потребно е да се добие вкупниот трошок за опремување на просторот. Откако ќе се одреди бројот потребно е да се определи единечната цена на секое парче мебел одделно. Преку помножување на бројот со одредената единечна цена ќе се добие вкупниот планиран трошок за одреденото парче мебел. Збирот на одделно добиените трошоци за секое парче мебел претставува вкупен трошок за опремување на просторот.

\footnotetext{
${ }^{23}$ Office Interior Design Guide, Rayfield K. Julie, стр.29-36
} 
Анализа на концептите на организација и опремување со мебел кај канцелариските простори магистерски труд Зејнелабедин Азири

\section{3. Анализа на ентериерот на канцелариските простори}

Во сегментот од трудот,анализа на ентериерот на канцелариските простори,направен е обид за анализа на дизајнот за канцелариските простори, одделно за двете намени: канцелариски простор на новинска агенција и канцелариски простор на правна канцеларија. Анализата на дизајнот на канцелариските простори во овие два субјекти е спроведена најнапред преку поделба на три делови.

Во првиот дел се прави анализа на проценка на големината на потребниот простор. Многу малку може да се спроведе во однос на дизајнот на еден канцелариски простор доколку не е направена проценка на потребниот простор со цел соодветно спроведување на целите и задачите на субјектот.Проценката на големината на потребниот простор е направена преку карактеризирање на факторите кои што влијаат врз големината на потребниот простор.Факторите кои што влијаат врз големината на потребниот простор се дизајнот на објектот, карактеристиките на работата која што се планира да се извршува во канцеларискиот простор, нивото на нужност од помошни простории (на пример, конференциска сала и сл.) и бројот на вработени во тековниот период и во иднина.

Во вториот дел се прави планирање на канцеларискиот ентериер. Иако во раните години од минатиот век соодветно уредување на ентериерот не било од голема важност за менаџментот на компаниите во денешно време тоа има голема улога при вработување на посакуваниот кадар како и за зголемување на ефикасноста на работата. Планирањето на канцеларискиот ентериер се врши преку согледување на следниве шест елементи, структура на внатрешноста на објектот, sидови и прегради, осветлување, под, вентилација и контрола на звук.

Во третиот, последниот дел се прави декорација и опремување на канцеларискиот простор преку селектирање на елементи потребни за соодветно извршување на работата како и нивната боја и дизајн. За потребите на опремувањето на ентериерот на канцелариските простори (новинската агенција и правната канцеларија) кои се предмет на разработка на овој труд, аплицирани се елементите мебел од претпријатието “Биротајм“"24.

Елементите предвидени со проектот за ентериерот на канцеларискиот простор во новинската агенција и правната канцеларија се групирани по намена.

- Во сегментот опремување на ентериерот претставен е мебелот кој што се користи за нотарот кај правната канцеларија и за генералниот уредник кај новинската агенција.Овој проект на канцелариски мебел има конструктивен систем на ослонување реализиран со ногари од плочест материјал (мдф со д=36мм) обложени со бел ламинат со посебно косо монтирање под агол со носечкиот елемент подконструкција на работната плоча. Работната површина е изведена од три видови на фурнири(тик, макоре или венге)нанесени на подлога од иверка со д=35мм. На сл.2 прикажан е овој модел на канцелариски мебел.

\footnotetext{
${ }^{24}$ http://www.burotime.com.tr/

Фирмата Биротајм е производител на канцелариски мебел и столици и претставува еден однајголемите производители на мебел во Турција. Фирмата е основана во 1997 година во градот Коња. Со своите функционални дизајни и модели со голем квалитет фирмата го има завземено местото на лидер во брендовите за мебел.Оваа фирма не е позната само во Турција туку и во многу други земји во светот.
} 


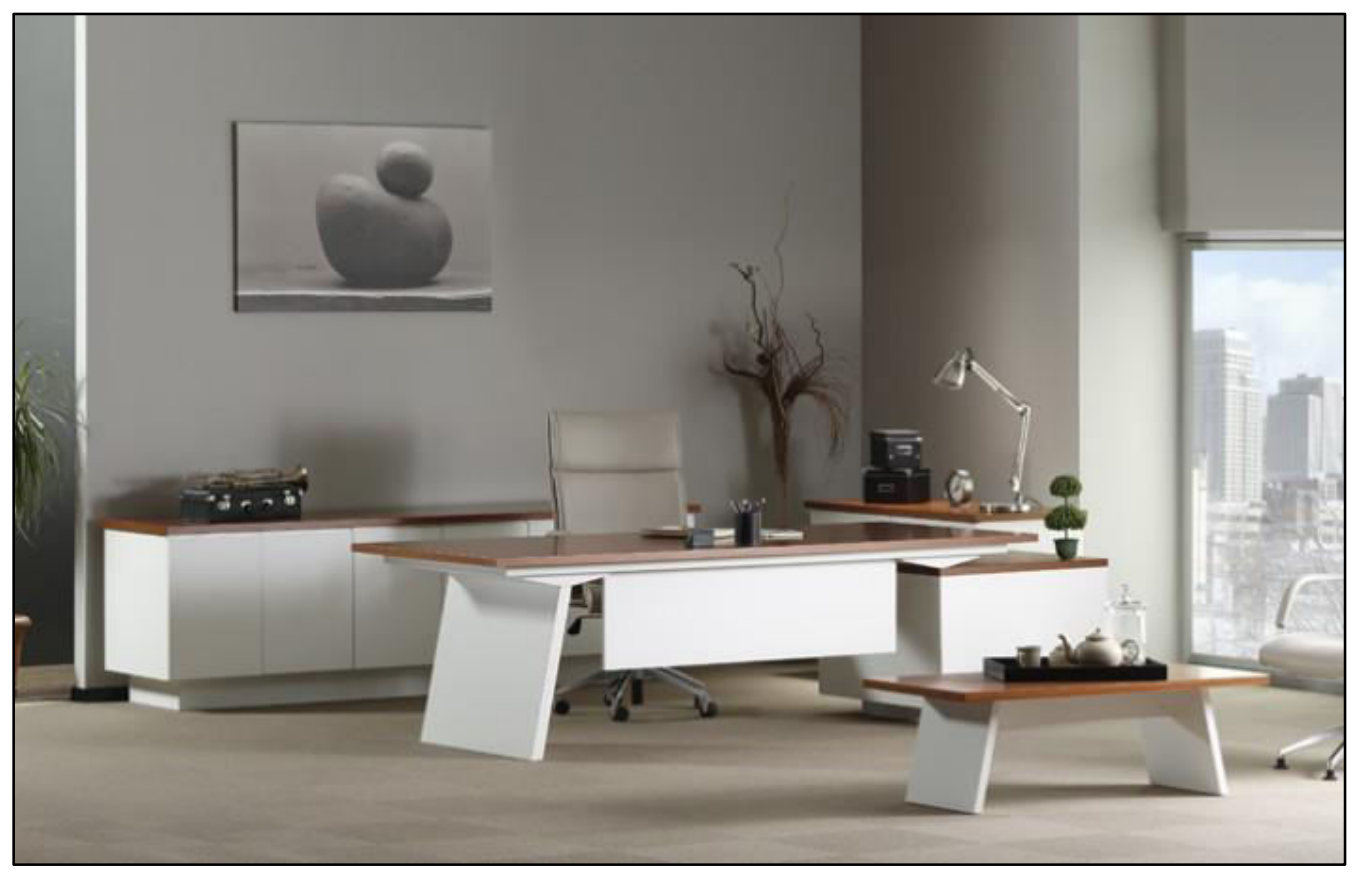

Слика.2Канцелариски мебел кај нотар и генерален уредник

- Мебелот кој се користи за опремување на одделните канцеларии за адвокатите (во правната канцеларија) и за лицето за односи со јавност (во новинската агенција) претставен е на сл.з.Овој дизајн на канцеларискиот мебел има систем на ослонување реализиран со ногари од плочест материјал(иверка со д=25мм.) поставени под прав агол во однос на работната површина обложени со ламинат во ефект на антрацит. Работната површина која е сместена над нив може да биде изведена од три видови на фурнири (тик, макоре или венге) на подлога од иверка со д=25мм. сите останати елементи кои кои го надополнуваат овој модел на канцеларија се изведени од истите материјали и го имаат карактеристичниот дизајн (додатно работно биро, низок елемент со фиоки, комода Н=120цм, комода Н=8оцм, клуб маса и сл.). 


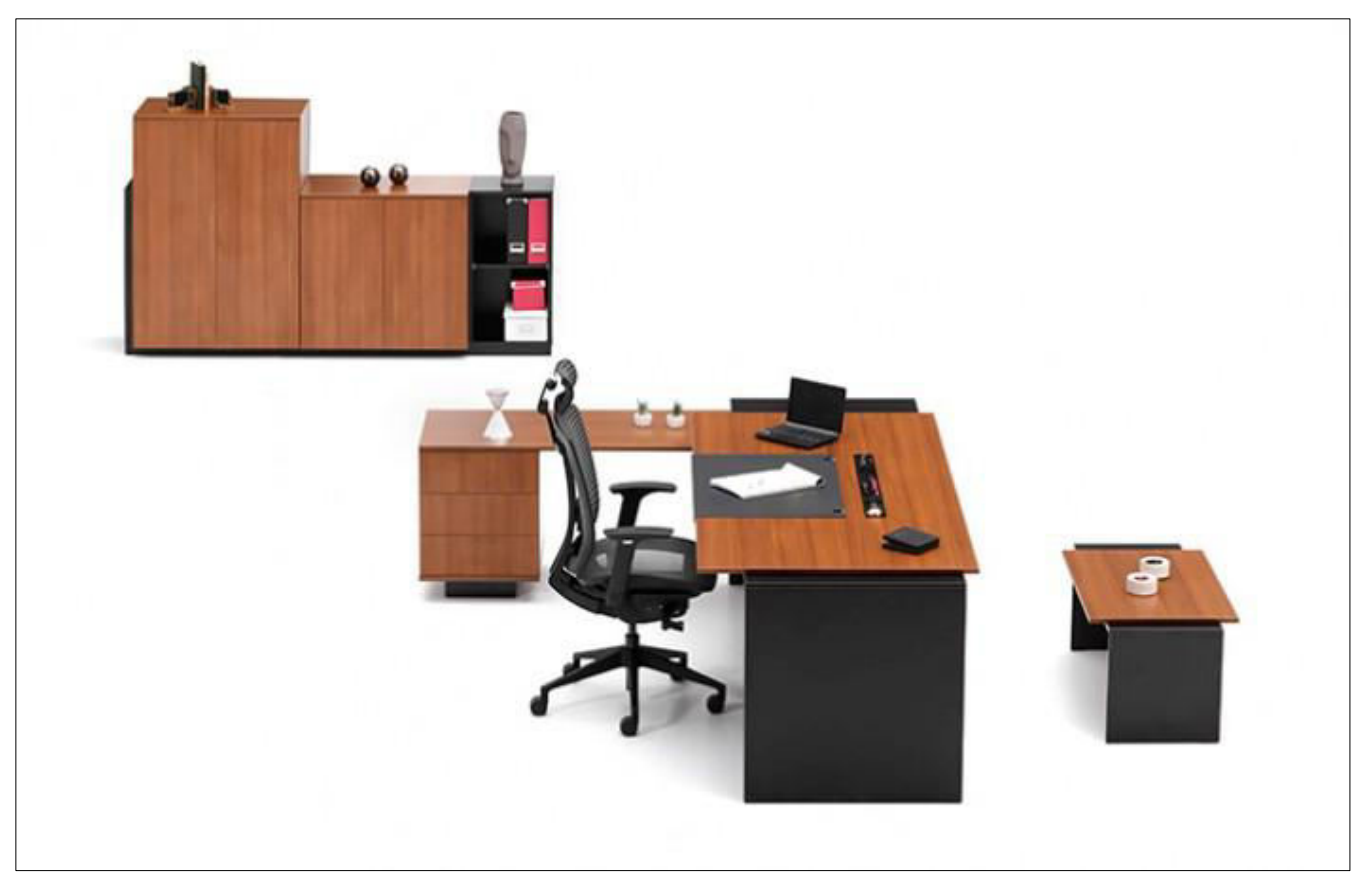

Слика.3Канцелариски мебел кај адвокати и лице за односи со јавност

- Мебелот кој се користи во канцеларијата од отворен тип, збирна за сите новинари во новинската агенција е претставен насл.4. Овој модел на канцелариски мебел има систем на ослонување реализиран со ногарки иверка (д=25мм)фурнирана со ламинат и завршена во ефект на антрацит сиво. Работната површина која што е сместена над нив може да биде изведена од иверка (д=25мм)фурнирана со ламинат во завршница (ефект) на цреша.

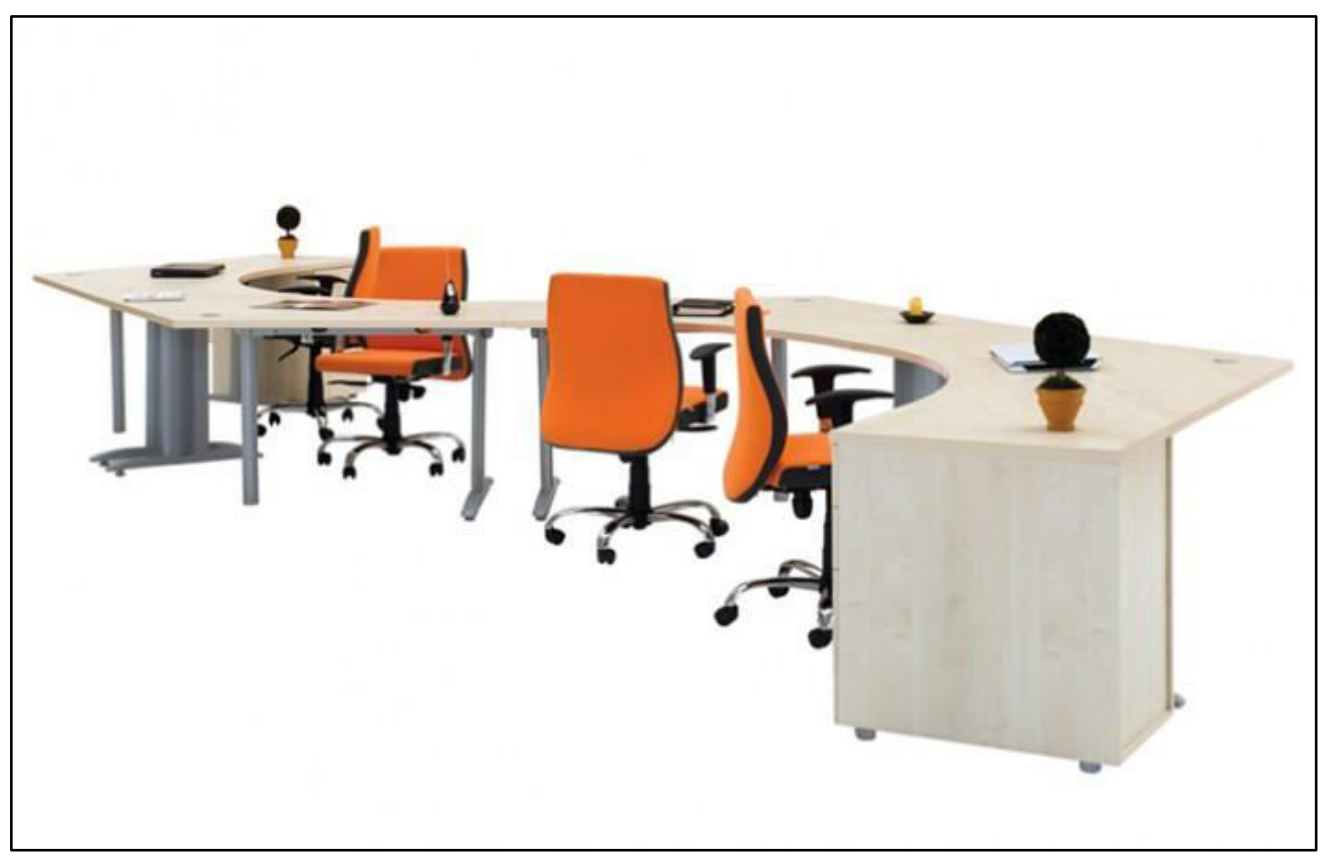

Слика.4Канцелариски мебел кај новинари 
- Овој модел на канцелариски мебел претставува оперативен производ и нуди стабилни и едноставни решенија за работни простории со повеќе од 2 лица. Овој вид на канцелариски мебел е дизајниран на таков начин што ги прикрива бројните кабли и конекции со мрежата, така што овозможува зачувување на уреденоста во канцеларијата.

- Мебелот кој се користи во просторијата за состаноци кај новинската агенција претставен е на сл. 5. Овој модел на канцелариски мебел има систем на ослонување реализиран со ногарки од плочест материјал иверка (д=25мм)фурнирана со ламинат и завршена во ефект со боја крем (рал303). Работната површина која што е сместена над нив предвидено е да биде изведена од иверка д=35мм фурнирана со природен фурнир од даб.Фотељите се во полиуретан на челична вградена потконструкција, тапацирани со еколошка кожа во ефект на крем боја, додека ногаркитесе вртливи на конструкција од инокс.

- Мебелот кој што се користи во просторијата за одмор кај новинската агенција претставен е насл.6. Делот за седење е изведен од два сегмента: метална потконструкција и седишта во полиуретан. Полиуретанот овозможува седишата да добијат одредена форма (пр. тука во форма на буквата “В“), да останат цврсти и со стабилен пресек и после долги години на користење, што е особено важно кај современиот дизајн на седишта или столови за чекални кои се почесто попримаат уникатен дизајн. полиуретанот потоа е тапациран во еколошка кожа со виолетова боја. Овој начин на дизајнирање е уникатен и исто така го зголемува конфорот при седењето. 25

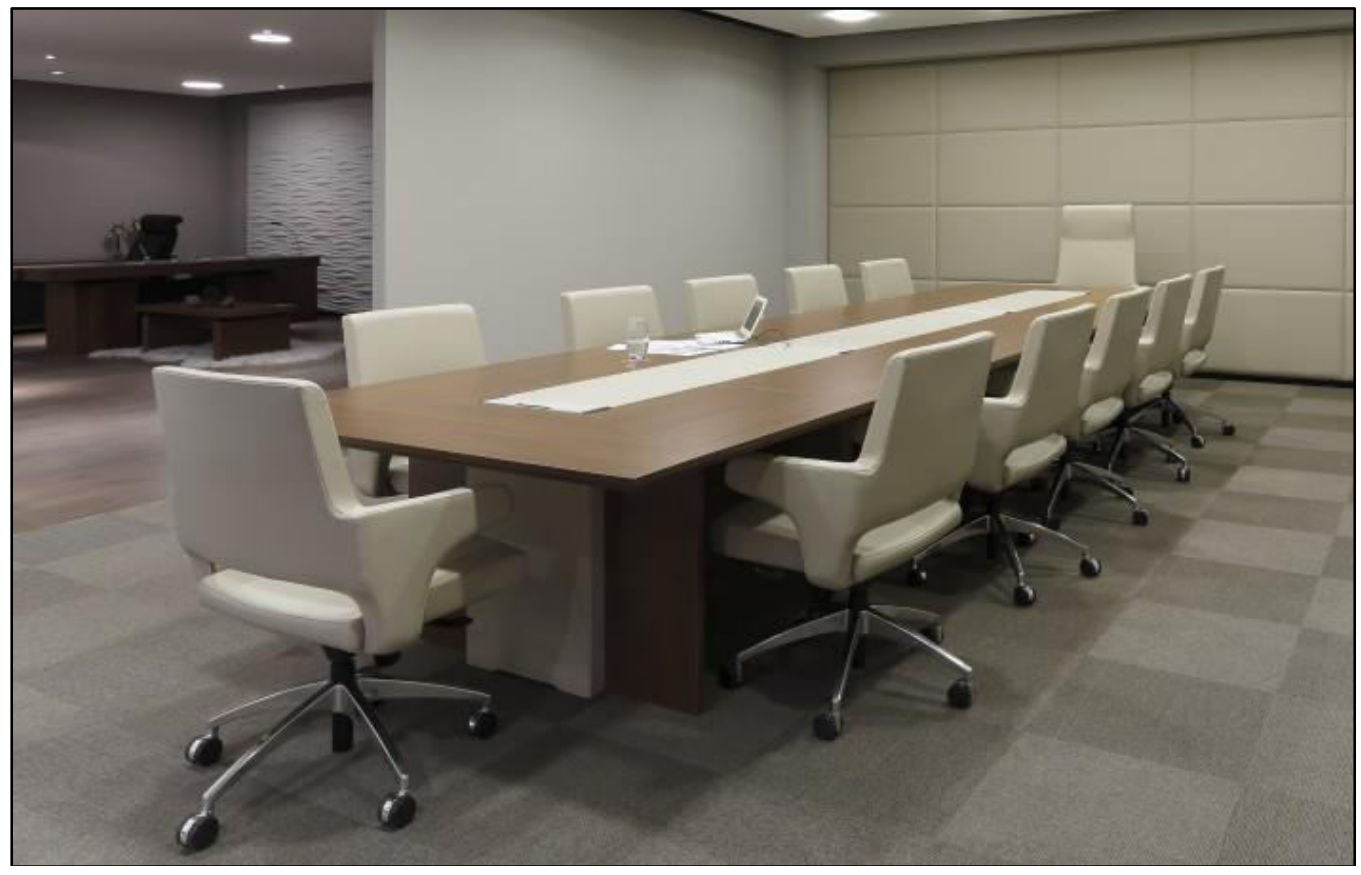

Слика.5Мебел во просторијата за состаноци

\footnotetext{
${ }^{25}$ http://www.burotime.com.tr/tr/urunler/ofis-mobilyalari/toplanti-ofis-mobilyalari/levels-toplanti-ofis-mobilyasi
} 


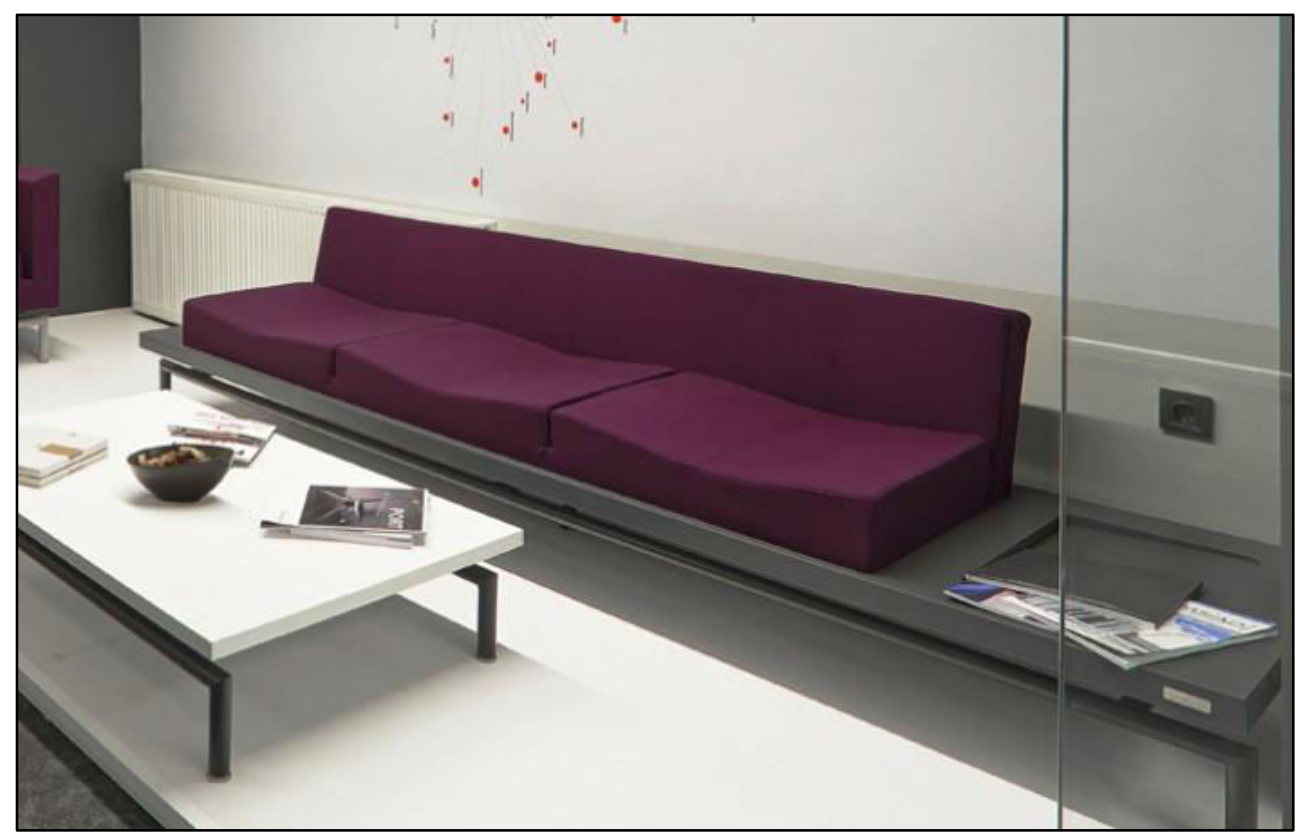

Слика.6Мебел во просторијата за одмор

Мебелот кој што се користи за седење во просторијата кај адвокатите во правната канцеларија претставен е во сл.7. Делот за седење е изведен од два сегмента: метална потконструкција и седишта во полиуретан. Полиуретанот овозможува седишата да добијат одредена форма (пр. тука во форма на буквата "В“), да останат цврсти и со стабилен пресек и после долги години на користење, што е особено важно кај современиот дизајн на седишта особено кај мебелот за опремување на канцелариските простори наменет за удобно седење (фотелји и двоседи или троседи) кои се почесто примаат уникатен дизајн ( како примерот тука во форма на буквата "B“). Полиуретанот потоа може да биде тапациран во еколошка кожа со светло зелена боја. ${ }^{26}$

\footnotetext{
${ }^{26}$ http://www.burotime.com.tr/tr/urunler/bekleme-grubu/lobi-bekleme/dem-saloon
} 


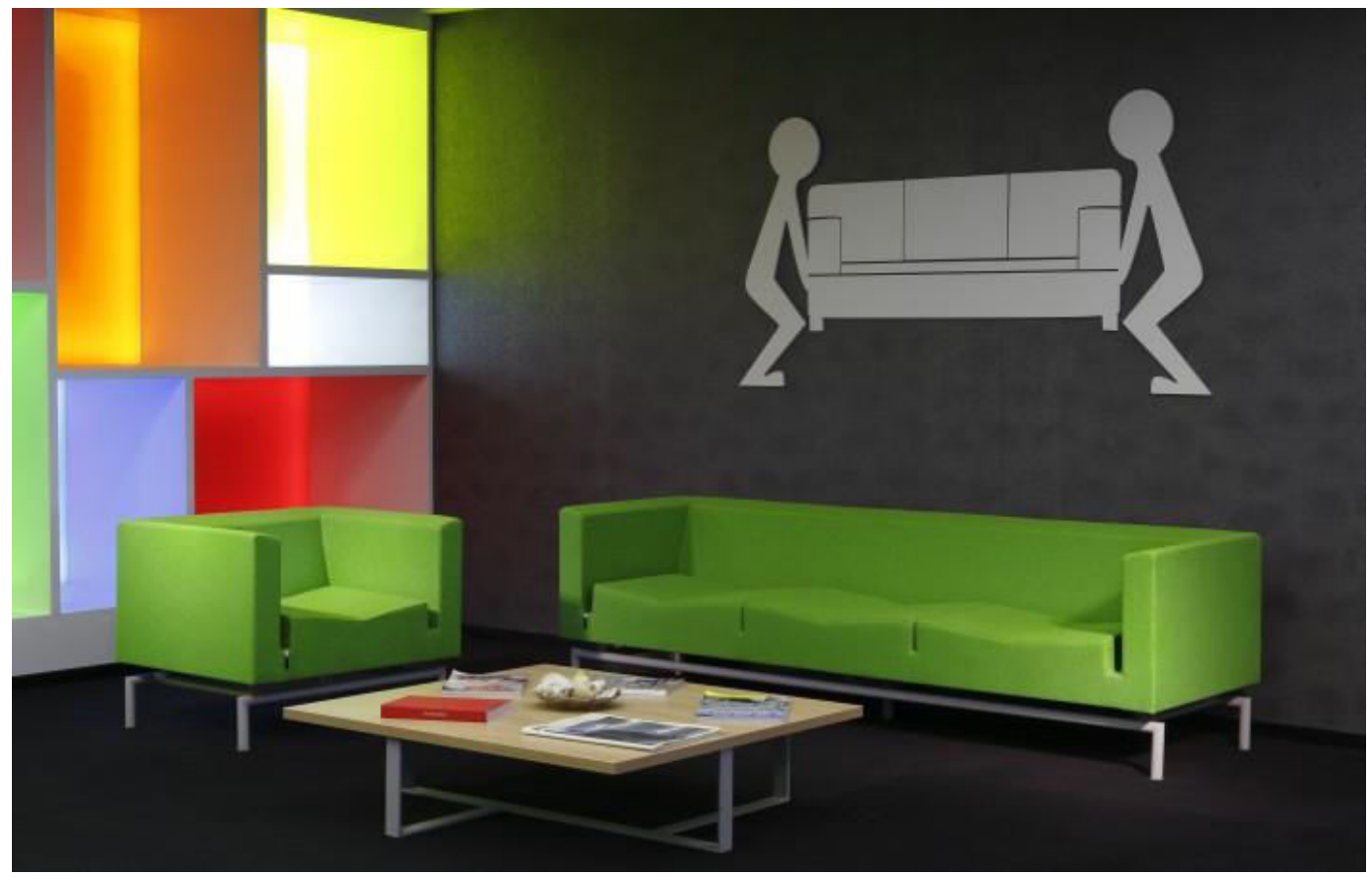

Слика.7Мебел во правната канцеларија

\section{1 Анализа на проектот за ентериер на канцеларискиот простор за новинската агенција}

Како што е наведено во претходните делови од овој труд, како местоположба на новинската агенција, која што е предмет на анализа, е избран дТЦ Мавровка.

\subsection{1 Проценка на големината на потребниот канцелариски простор на новинска агенција}

Проценката на големината на потребниот канцелариски простор на новинската агенција направена е преку карактеризирање на факторите кои што влијаат врз големината на потребниот простор. Најпрвин се согледува дизајнот на објектот. Формата и големинатана канцеларискиот простор, кој што се користи за новинската агенција, се прикажани во Цртеж.4. Покрај димензиите на просторот исто така треба да се земат во предвид и носечките столбови чија што позиција исто така е прикажана во Цртеж.8.

Следно, нешто кое што треба да се согледа е карактеристиката/природата на работата која што ќе се извршува. На крајот од овој дел ќе треба да се одреди каков вид на простор ќе се оддели за секој вработен посебно, отворен или затворен и која ќе биде големината на секоја простор одделно.

Новинската агенција, предмет на анализа, вработува 14 луѓе, кои што се подделени во следниве функции:

- 1 генерален уредник (директор)

- 1 секретар

- 1 лице за односи со јавност

- 10 новинари

- 1 лице за оддржување на канцеларискиот простор 
Во новинската агенција, просторот ќе биде од отворен тип. Само просторот наменет за генералниот уредник и за лицето за односи со јавност е од затворен тип но овие простори се преградени со прозирен материјал. Предностите на отворениот тип на канцелариски простор се ефикасното искористување на просторот, поголема флексибилност при планирање, визуелен пристап до другите вработени, полесна комуникација и помал трошок при работа. Исто така, отворениот тип на канцелариски простор, овозможува брзо реагирање при појава на потреба од зголемување на капацитетот или потреба за реорганизирање на распоредот во просторот. 


\section{Постоечка состојба на Деловен простор Мавровка 8 кат}

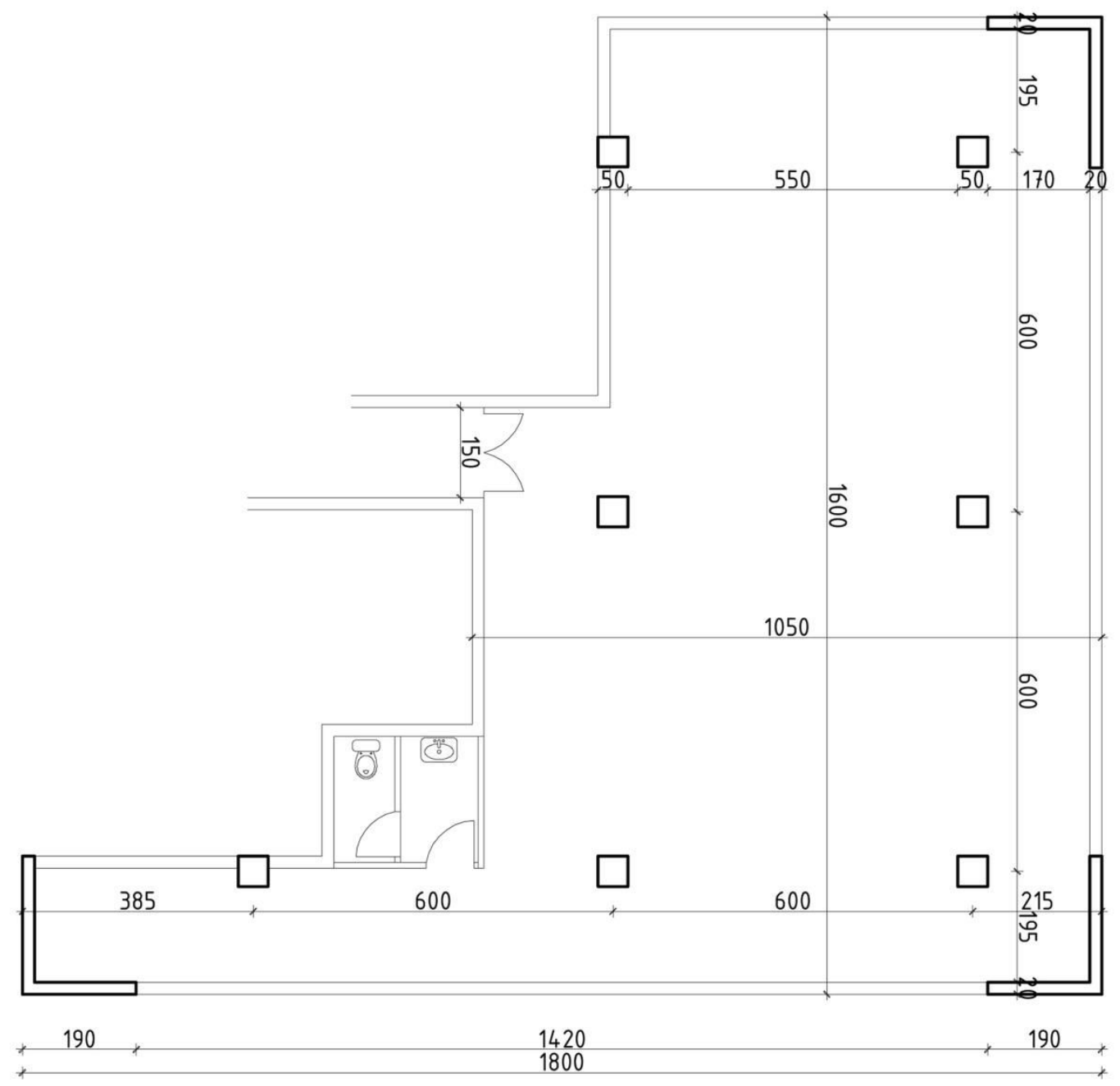

\section{Основа}

\section{$\mathrm{M}=1: 100$}

Цртеж.8 Форма и димензии на канцеларискиот простор предвиден за уредување на ентериерот и опремување со мебел / за новинската агенција / за правната канцеларија 


\section{Новинска агенција}

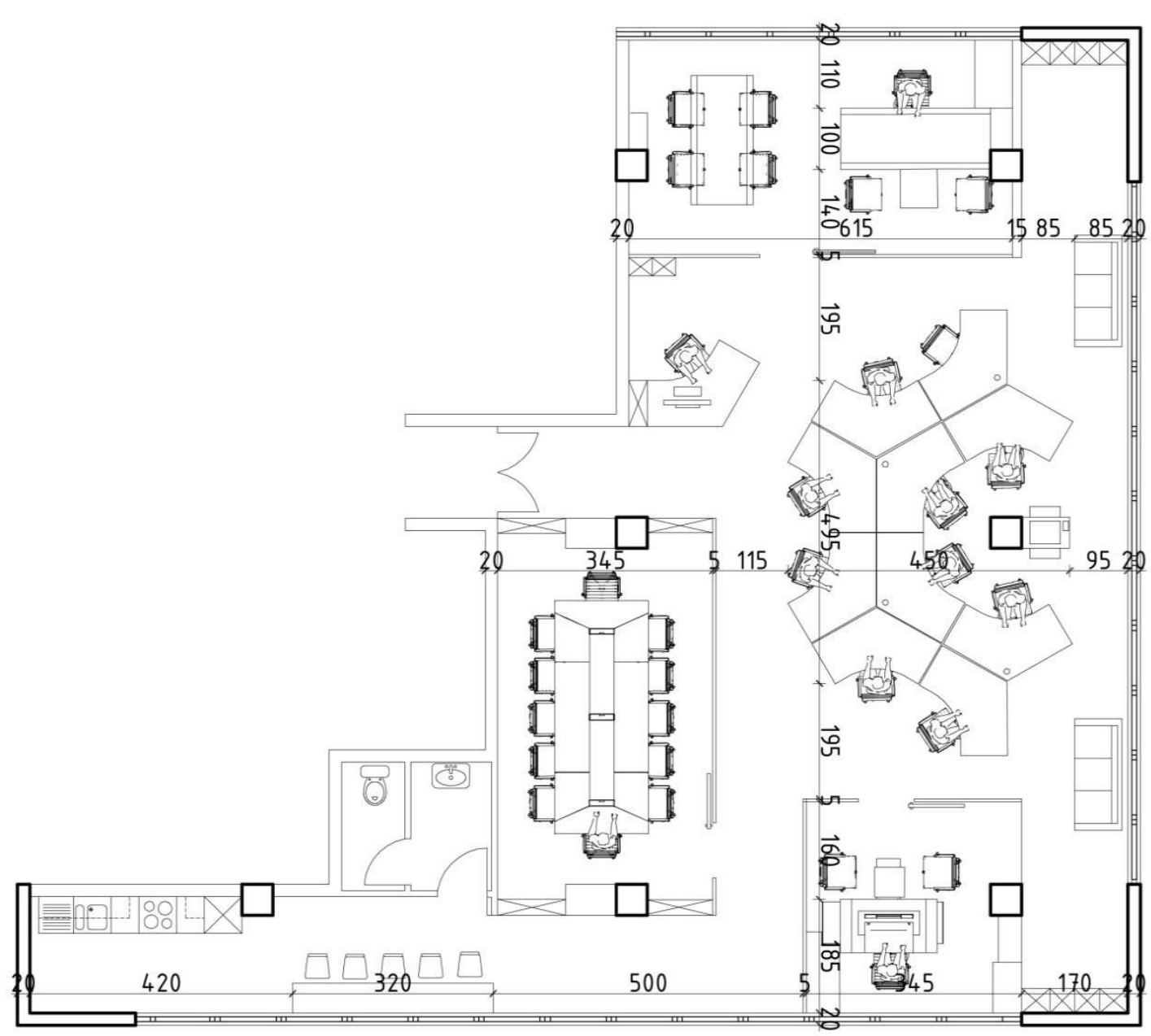

\section{Основа $\mathrm{M}=1: 100$}

Цртеж.9 Канцеларискиот простор во новинската агенција, опремена со мебел 


\section{Новинска агенција}

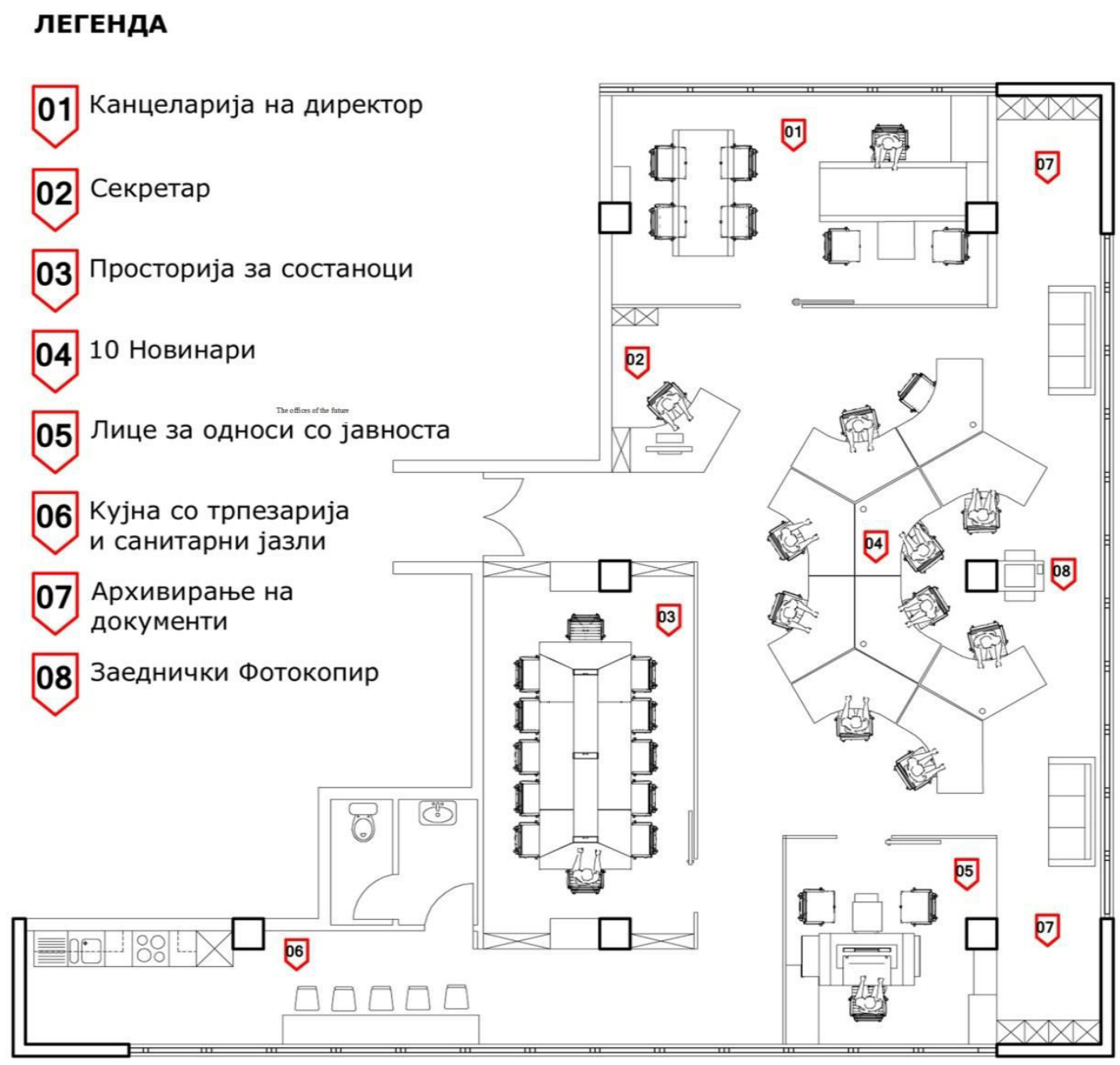

\section{Основа $\mathrm{M}=1: 100$}

Цртеж.10 Канцеларискиот простор во новинската агенција - функционална поделба по простории 


\section{Новинска агенција}

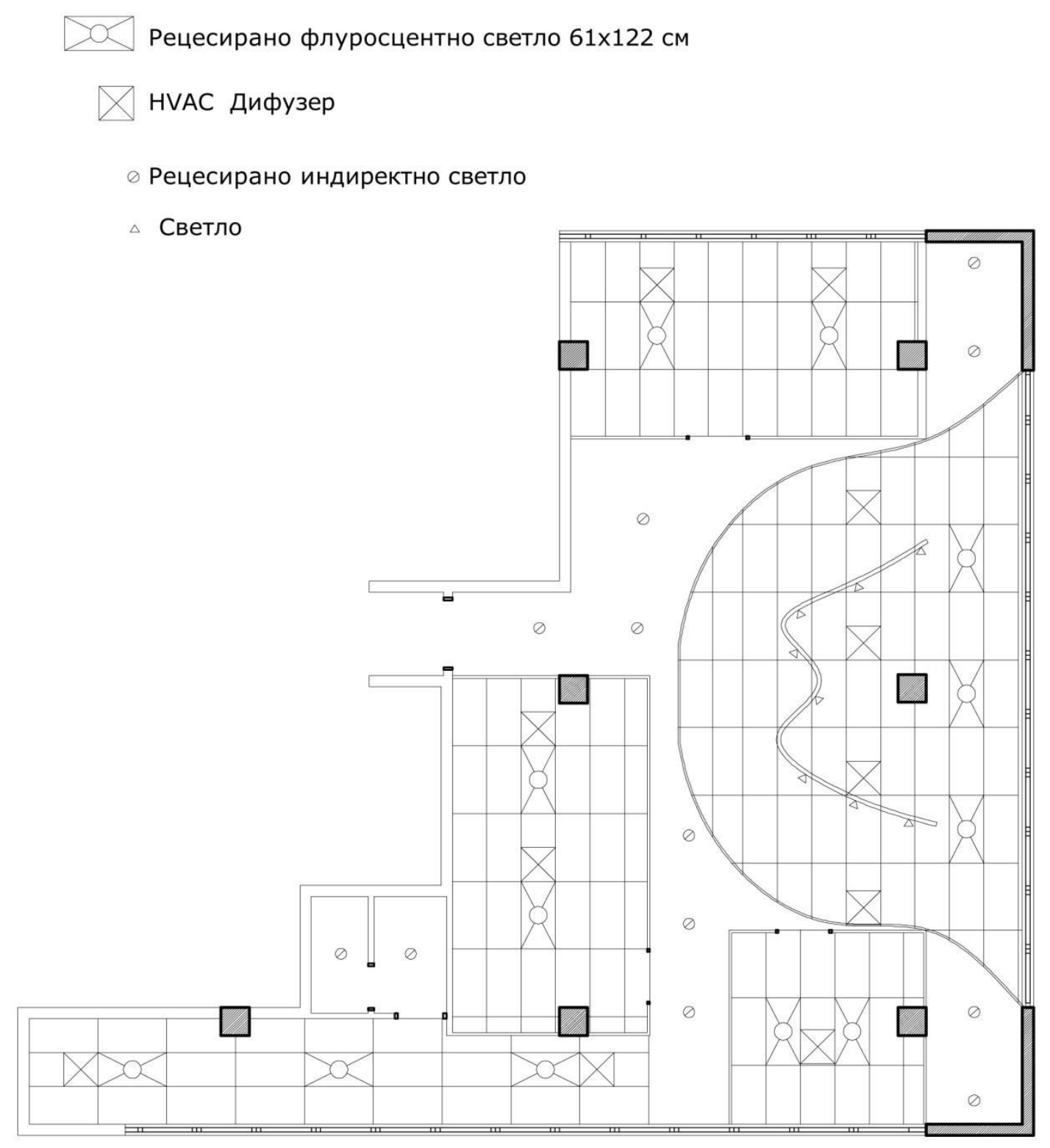

Основа на спуштена таваница кај ентериерот на новинската агенција $\mathrm{M}=1: 100$

Цртеж.11 Основа на спуштена таваница кај ентериерот на новинската агенција 
Анализа на концептите на организација и опремување со мебел кај канцелариските простори магистерски труд Зејнелабедин Азири

Иако исто така овој тип на отворен простор има негативни страни како што се, поголем првичен трошок и недостаток од визуелна приватност, сепак согледувајќи ги неговите предности, овој тип на канцелариски простор е најсоодветен за ефикасно извршување на обврските во новинската агенција.

Сепак, изборот на примена на отворен тип или затворен тип не се состои од избор помеѓ коректен или погрешен начин туку двата типа на простор претставуваат засебен начин на пристап кон дизајнирањето на еден простор. На крај од одлуката секој субјект потребно е да го избере оној пристап кој што најдобро соодејствува на активностите кои што субјектот ги извршува.

Подолу е направена одделна анализа на секој простор во новинската агенција.

- Активностите на генералниот уредник повеќе се основаат на читање на одреден материјал и средби со одредени вработени или лица кои што доаѓаат надвор од компанијата. Притоа генералниот уредник има потреба од голем и затворен канцелариски простор. Затворениот простор ќе му овозможи на генералниот уредник да биде заштитен од звучно вознемирување од гужвата во останатиот дел од канцеларискиот простор како и од разговорот помеѓу останатите вработени.

Исто така, активностите кои што генералниот уредник ќе ги извршува нема да бидат предмет на следење од страна на останатите вработени (на пример, телефонски разговор со важна личност). На крај, овој простор автоматски му доделува статус на важна личност во агенцијата, нешто од кое генералниот уредник има потреба за полесно управување со обврските на агенцијата. Овој простор ќе биде преграден со прозирен материјал.

- Активностите на секретарот повеќе се основаат на разговор со генералниот уредник, со вработените и со лица надвор од агенцијата. Притоа има потреба од отворен простор кој што не е заштитен со материјал и истиот е лоциран во близина на влезот на агенцијата. На овој начин секретарот ќе биде во директна комуникација со останатите вработени во канцеларијата и исто така ќ биде прво лице за контакт за оние лица кои што доаѓаат од надвор.

- Активностите на лицето за односи со јавност почесто се основаат на читање на одреден материјал како и средби со вработените во агенцијата но почесто со лица кои што доаѓаат надвор од агенцијата. Притоа лицето за односи со јавност има потреба од затворен простор заштитен со прозирен материјал. На овој начин, лицето за односи со јавност ќе може целосно да биде впуштен во извршувањето на своите активности без притоа да биде вознемируван од останатите вработени.

- Активностите на новинарот почесто се основаат во истражување, внатре или надвор од агенцијата и подготовка на одреден материјал. Притоа новинарот има потреба од отворен простор. На овој начин новинарот ќе има можност за полесна размена на мислење со останатите новинари во канцеларијата.

- Активностите на лицето за оддржување на канцеларискиот простор почесто се основаат на послужување на вработените или гостите со одреден пијалок или храна и хигиенскооддржување на просторот. Притоа лицето за оддржување на канцеларискиот простор има потреба од затворен простор каде што би бил сместен 
потребниот инвентар за соодветно спроведување на обврските.

Откако е направена одлука за видот на просторот одделен за секој вработен, затворен или отворен, следен чекор е да се одреди големината на секој одделен простор.

1. Просторот кој што е одделен за генералниот уредник е со првична големина од 22 метри квадратни (6,15 метри х 3,6 метри). Големината на овој простор е во рамките на предложените стандарди во книгата на Robichaud Beryl-Selecting Planning and Managing Office Space.4Согласно стандардот, овој простор е доволен за лоцирање на едно биро, еден плакар, две столици и една помошна маса со четири столици.

2. Првичната големина на просторот одделен за секретарот изнесува 6,25 метри квадратни (2,5 метри х 2,5 метри). Оваа големина ќе биде доволна за лоцирање на бирото кое што ќе биде користено од страна на секретарот како и столот на кој што ќе седи. Исто така, овозможен е простор за слободно движење. 

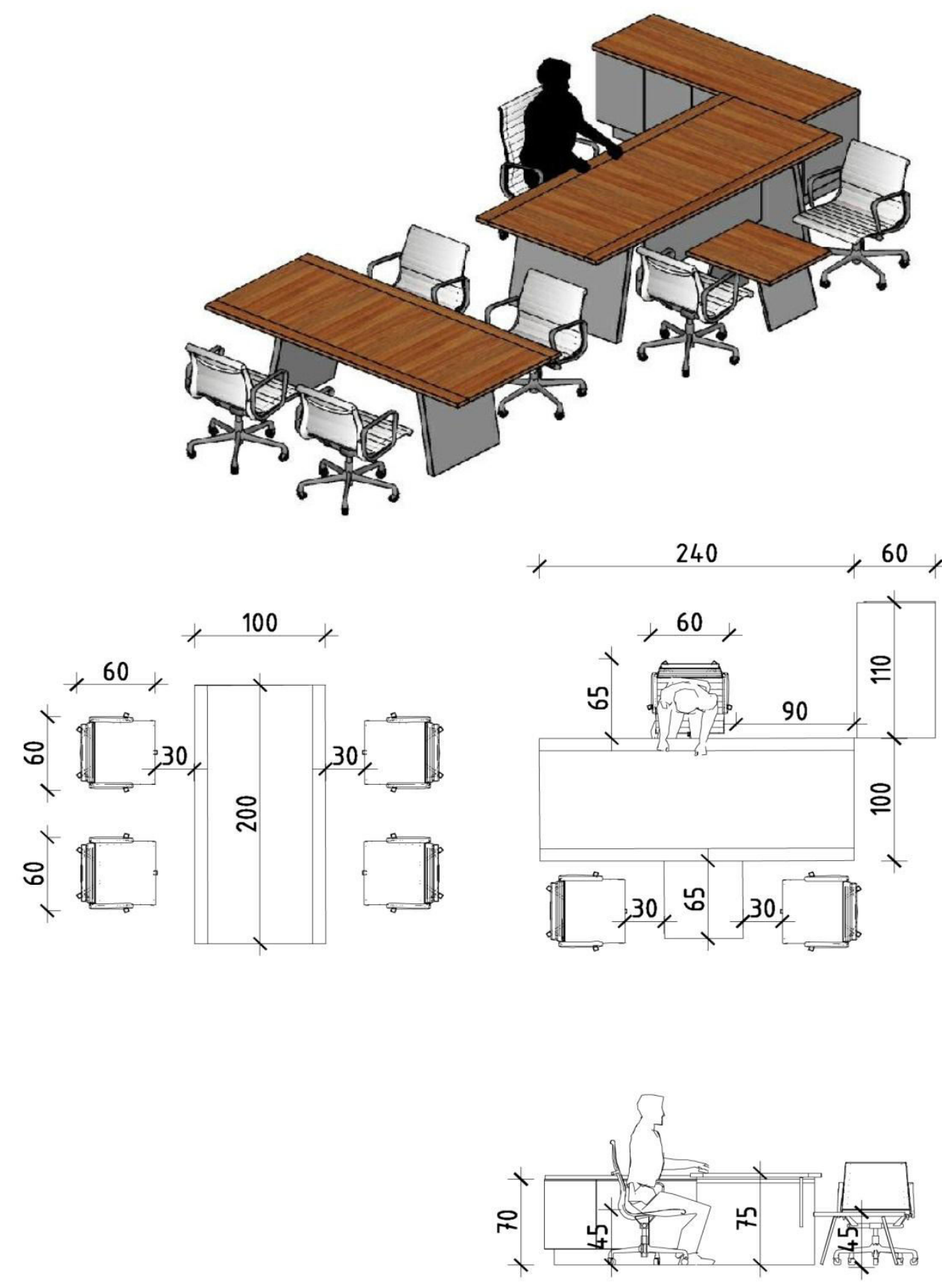

ОСНОВА И ПРЕСЕК СО АКСОНОМЕТРИСКА ПРЕСТАВА НА ПРОСТОРИЈАТА ЗА ГЕНЕРАЛЕН УРЕДНИК(ДИРЕКТОР)

$M=1: 50$

Цртеж.12Основа и пресек со аксонометриска престава на просторијата за генерален уредник кај новинската агенција 
Анализа на концептите на организација и опремување со мебел кај канцелариските простори

магистерски труд Зејнелабедин Азири

3. Просторот кој што е одделен за лицето за односи со јавност е со првична големина од 12 метри квадратни (3,45 метри х 3,45 метри). Големината на овој простор е во рамките на предложените стандарди во книгата на Robichaud Beryl-Selecting Planning and Managing Office Space4Согласно стандардот, овој простор е доволен за лоцирање на едно биро, еден плакар, една полица и две столици со мала масичка. Во Цртеж.13, претставени се основа и пресек со аксонометриска престава на просторијата за лицето за односи со јавност.

4. Големината на просторот кој што е одделен за новинарите изнесува 58,5 метри квадратни (6.6 метри х 8,9метри). Големината на овој простор е согласно стандардите за отворен канцелариски простор наведен во книгата на Robichaud Beryl-Selecting Planning and Managing Office Space.4 Стандардот кој што е земен во предвид се однесува за биро со широчина од 60 инчи (1,5 метри) должина и стол за седење и лоцирање на двајца вработени во еден ред. Потребната површина за еден вработен согласно овој стандард изнесува 55 метри квадратни (5 метри квадратни). Во Цртеж.14, претставени се основа и пресек со аксонометриска престава на просторијата за новинарите.

5. Следен чекор во одредувањето на потребниот канцелариски простор е да се одреди потребната големина на помошните простории. Помошните простории кои што се потребни за новинската агенција се една сала за состаноци која што ќе биде затворена со прозирен материјал, кујнски простор,еден тоалетсо посебна соба со мијалник и простор за одморање и разговор.

6. Големината на салата за состаноци изнесува 26 метри квадратни $(3,45$ метри х 7,5 метри). Големината на салата е во согласност со стандардите за овој вид на простории во светски развиените средини. ${ }^{27}$ Стандардот кој што е земен во предвид се однесува на сала која што може да собере 14 лица и чија што големина изнесува 300 квадратни стапки (28 метри квадратни). Во Цртеж.15, претставени се основа и пресек со аксонометриска престава на просторијата за конференциската сала.

${ }^{27}$ Robichaud Beryl-Selecting Planning and Managing Office Space, стр 44 и 53 

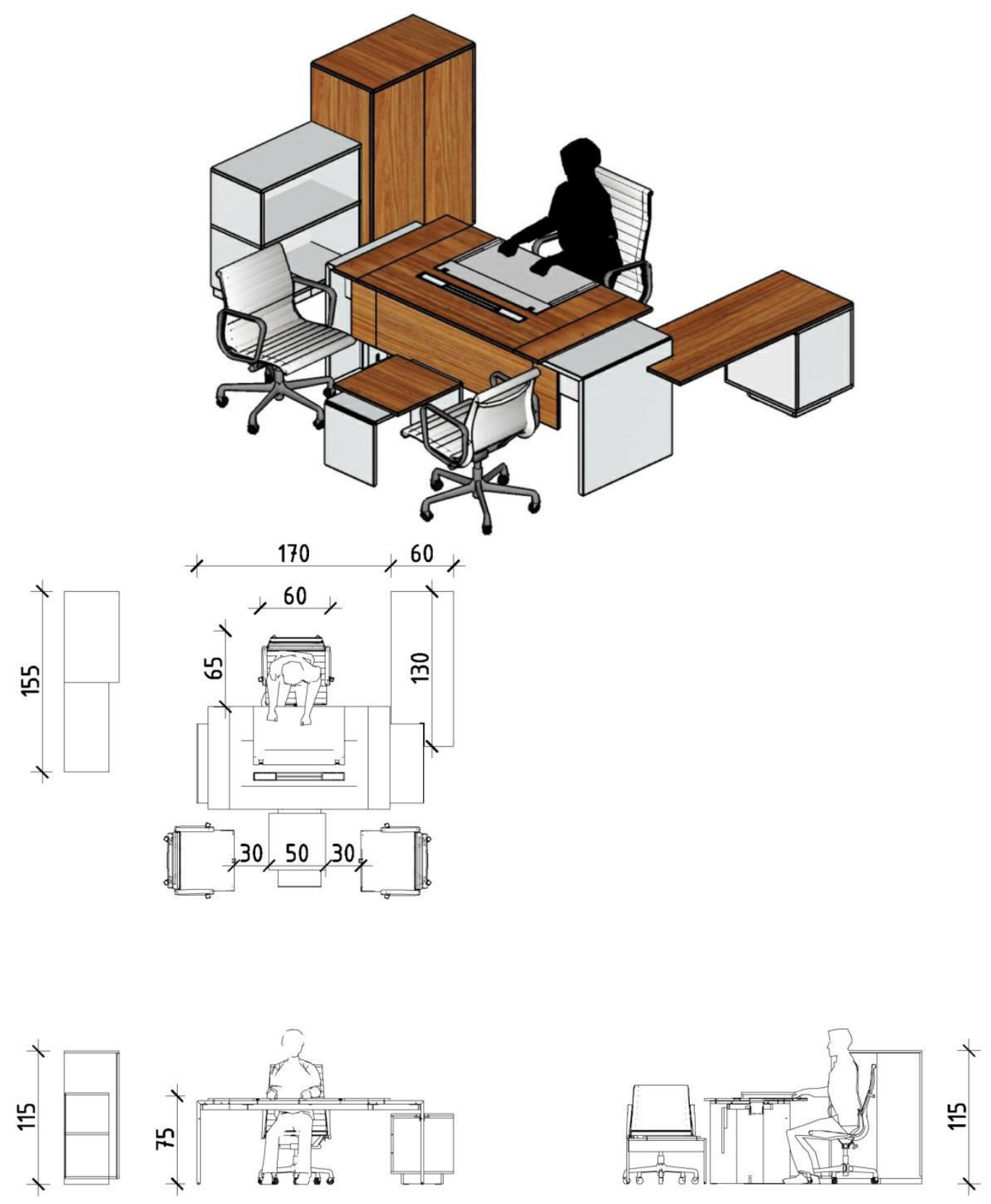

ОСНОВА И ПРЕСЕК СО АКСОНОМЕТРИСКА

ПРЕСТАВА НА ПРОСТОРИЈАТА ЗА ЛИЦЕ ЗА ОДОСИ СО ЈАВНОСТ $M=1: 50$

Цртеж.13Основа и пресек со аксонометриска престава на просторијата за лицето за односи со јавност кај новинската агенција 

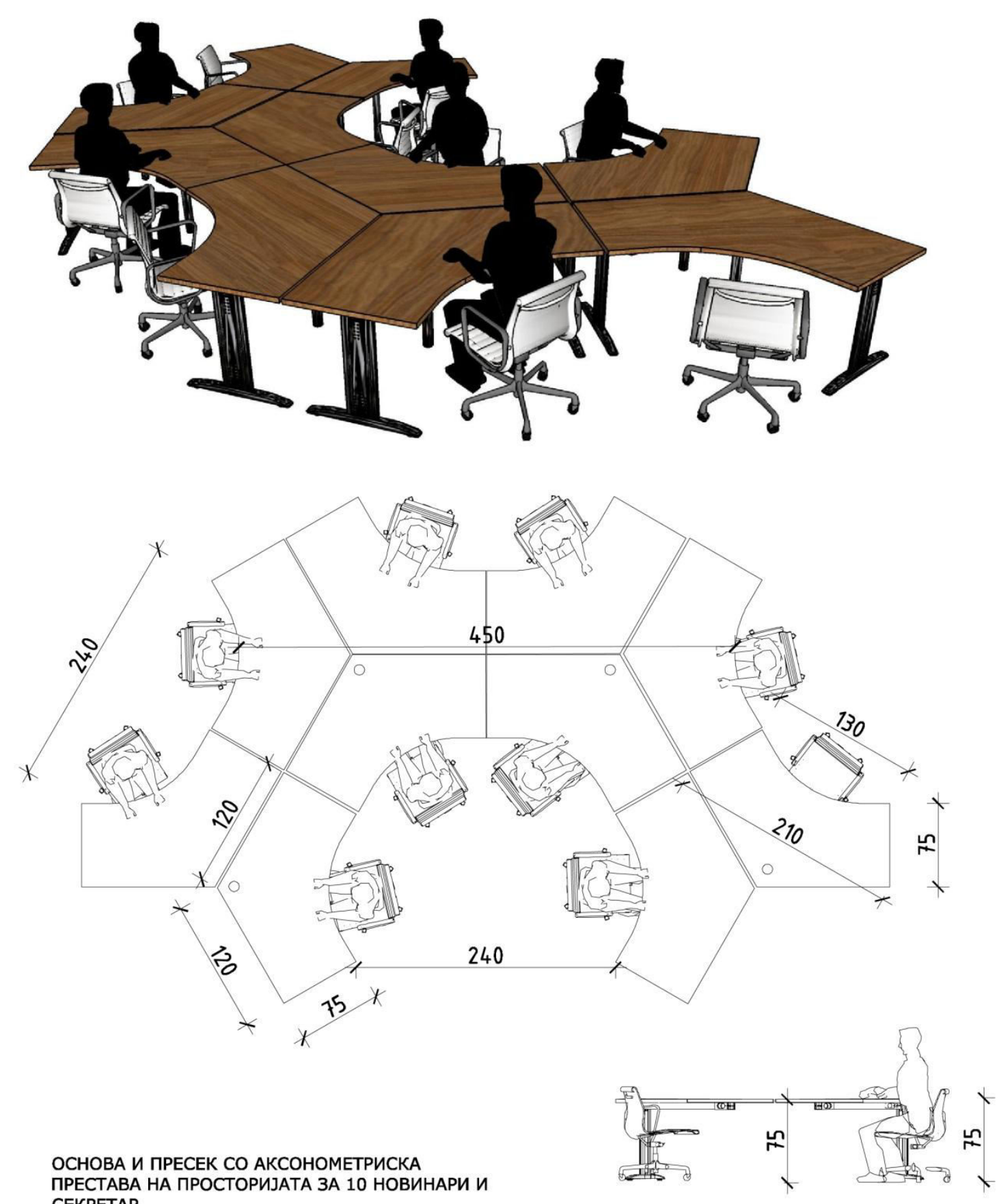
CEKPETAP $M=1: 50$

Цртеж.14Основа и пресек со аксонометриска престава на просторијата за новинарите кај новинската агенција 

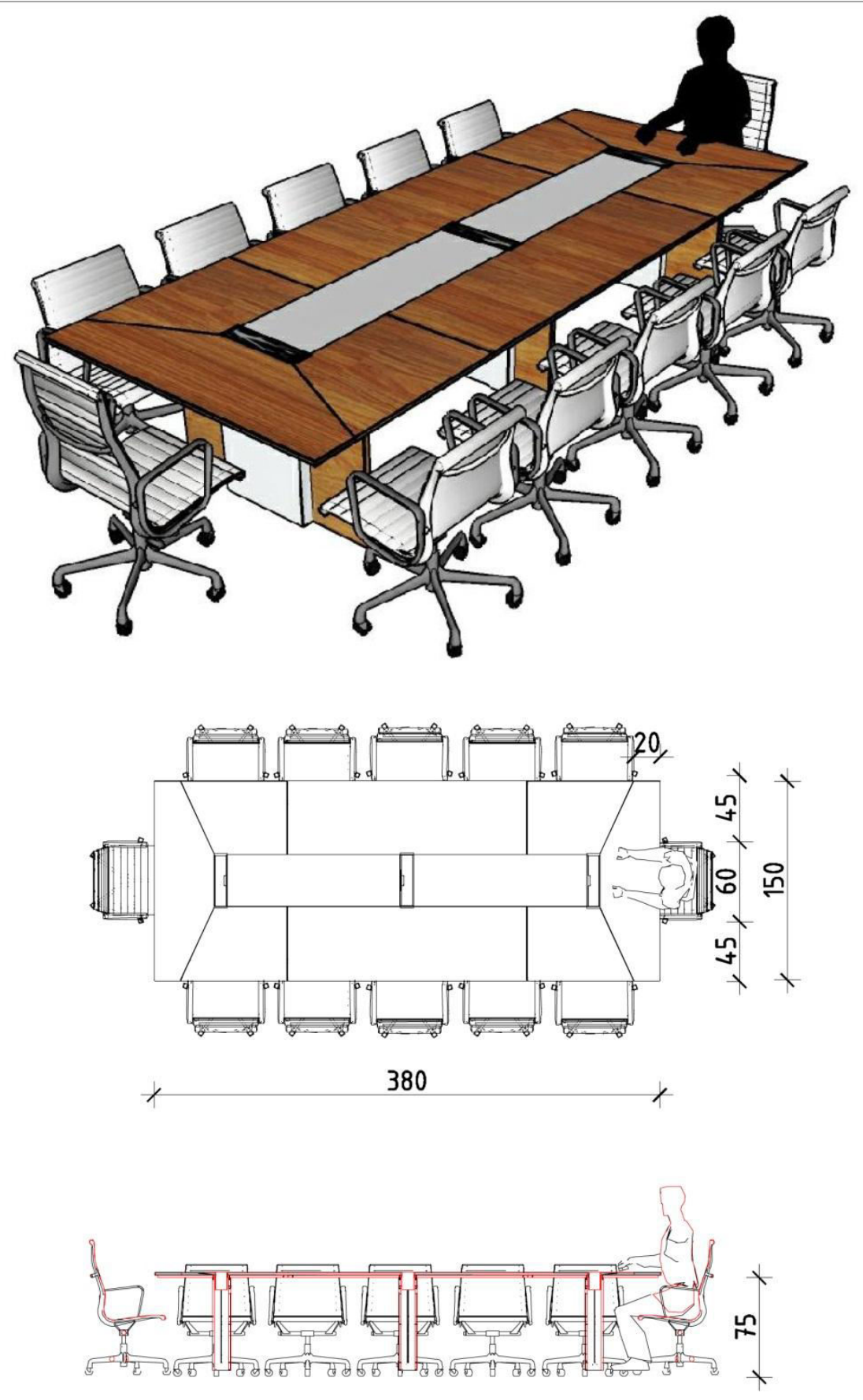

ОСНОВА И ПРЕСЕК СО АКСОНОМЕТРИСКА ПРЕСТАВА НА ПРОСТОРИЈА ЗА СОСТАНОЦИ $M=1: 50$

Цртеж.15Основа и пресек со аксонометриска престава на просторијата за просторијата за состаноци кај новинската агенција 
Анализа на концептите на организација и опремување со мебел кај канцелариските простори магистерски труд Зејнелабедин Азири

8. Кујнскиот простор е со големина од 8метри квадратни (4,2 метри х 1,85 метри). Во овој простор ќе има можност да се лоцира фрижидер, шпорет и мијалник за садови. Искористен е дополнителен простор за маса и столици за јадење.

9. Просторот кој што е одделен за тоалетот е со големина од 6,2 метри квадратни (2,3 метри х 2,7 метри). Овој простор ќе биде поделен во два дела од кој едниот има само мијалник додека другиот простор има само тоалет школка. Големината на овој простор е во согласност на предложените димензии за тоалет. ${ }^{28}$

10. Во канцеларискиот простор има два дела за одмор во кои што е сместен по еден кауч (софа). Во овој простор вработените може да се одмораат, да читаат одреден материјал и слични активности.

\subsection{2 Планирање на ентериерот на новинската агенција}

Планирањето на канцеларискиот ентериер за новинската агенција започнува преку согледување на структурата на објектот.Внатрешните носечки столбови во канцеларискиот простор се оддалечени едни од други во должина од околу 5 метри.Во однос на висината на таванот, со цел поудобен ентериер, пожелно е висината да биде поголема од 8 стапки (2,4 метри).

Следен чекор при планирањето на канцеларискиот ентериер е да се согледаат sидовите или преградите кои што ќе се користат за обележување на просторот за одредени вработени. Во канцеларискиот простор кај новинската агенција, само просториите наменети за генералниот уредник, лицето за односи со јавност и конференциската сала ќе бидат преградени со стакло. Стаклото кое што ќе се користи за преградување на овие простори ќе биде од фирмата “Фарам“ и истиот е претставен на сликата подолу, Слика.8.Кујнскиот простор нема да биде преграден, додека просторот за тоалет ќе биде преграден со цигли.

Стаклото се користи за изведба на внатрешните прегради во канцеларискиот простор поради неговата транспарентност, и едноставен, а современ израз која овозможува просторот да се доживува како флуиден. За оваа цел ќе се користи зајакнато стакло кое што е еден од видовите на стакла кои што се користат за оваа намена. Овој вид на стакло има поголема цврстина од нормалното стакло бидејќи при негово производство поминува низ неколку термички и хемиски третмани.Преградните стаклени sидови ќе бидат прицврстени на алуминиумски рамки. Висината на sидовите ќе биде до таванот. Дебелината на стаклото ќе биде 10 мм. Една од причините поради која што новинарите имаат отворен простор е да се има полесна комуникација и размена на информации.

\footnotetext{
${ }^{28}$ http://houseandhome.com/design/bathroom-planning http://www.houseplanshelper.com/bathroom-dimensions.html
} 
Анализа на концептите на организација и опремување со мебел кај канцелариските простори магистерски труд Зејнелабедин Азири
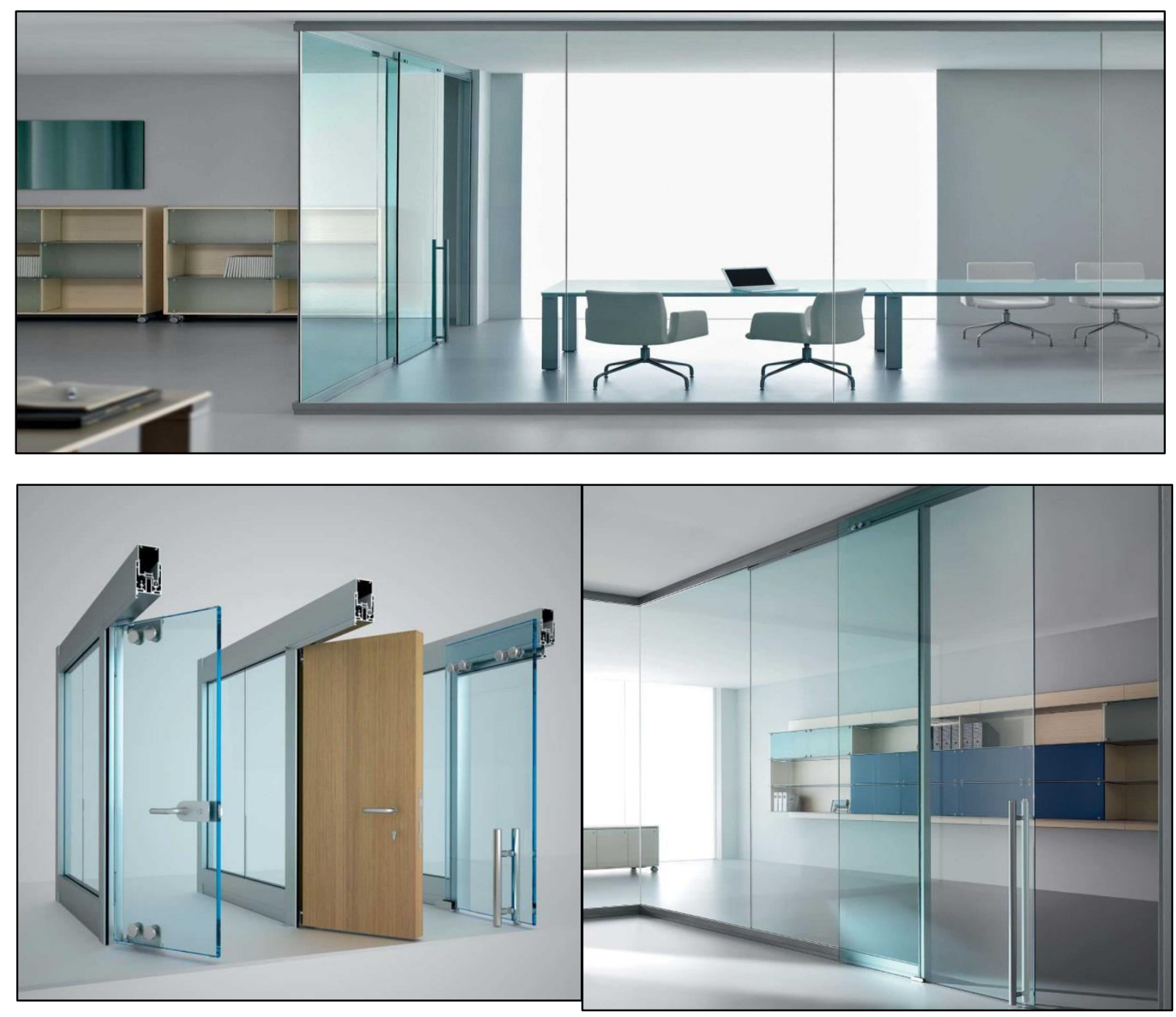

Слика.8 Материјал користен за преграда на просториите

Сите овие прегради би требало да се изведат со висина идентична со таа на таванот. На овој начин, лицето/лицата во преградениот простор ќе бидат целосно физички изолирани и нема да бидат вознемирувани од звуците кои што доаѓаат надвор од канцеларијата.

Следен фактор на кој што во проектот би требало да му се даде особено внимание е осветлувањето, поради неговото големо влијание врз квалитетот на работењето, амбиентот, просторот за работа. Во канцеларискиот простор кај новинскатаагенција потребна количина на светло е 50 FC. ${ }^{29}$ Овој стандард за количина на светлина се однесува на проектите за генерален канцелариски простор и приватни канцелариски простори. Системот за осветлување кој што е избран е со директно осветлување каде што светилките

\footnotetext{
${ }^{29}$ Robichaud Beryl-Selecting Planning and Managing Office Space
} 
се од видот компактни, флуоресцентни.

Изборот припаѓа на овој вид светилки бидејќи овој вид обезбедува три пати повеќе светлина за еден ват, има шест пати подолг рок на траење и испушта помалку топлина во однос на инкандесцентната светилка. Овој систем за осветлување е вграден во спуштениот тавансоодветно на сстандардите за вградување светилки и ПП заштита.

Следен чекор при планирањето на ентериерот е избор на покривката на подот. Во просторот одделен за генералниот уредник, лицето за односи со јавност и просторијата за состаноци подот ќе биде покриен со тепих додека подот кај останатите делови од канцеларискиот постор ќе биде покриен со керамички плочи (6о/6оцм). Во Цртеж.16, подобро е прикажан подот.

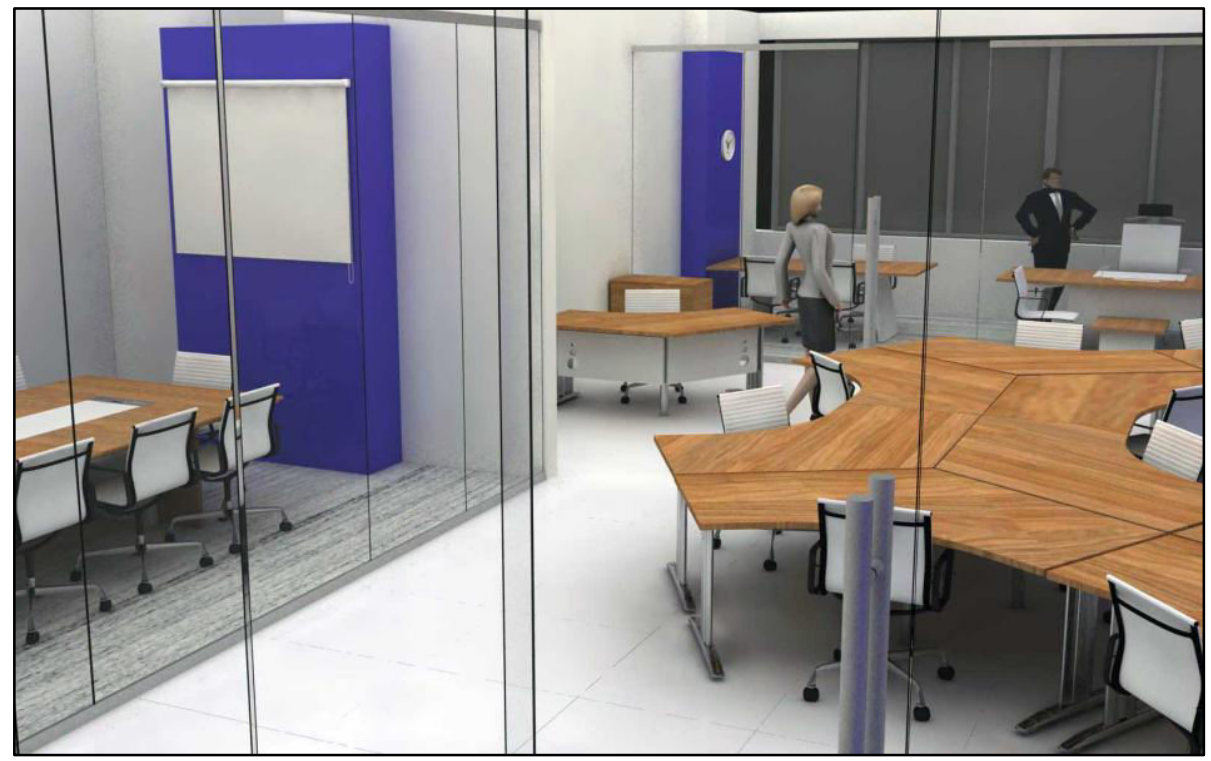

Цртеж.16 Преглед на подот кај канцеларискиот простор во новинската агенција

Со цел да се обезбеди соодветна температура, влажност, свежина, чистота и циркулација на воздухот во канцеларискиот простор потребно е да се има систем за вентилација. Системот за вентилација кој што ќе се користи во новинската агенција е централен систем за вентилација. Овој вид на систем ќе биде во можност да ги одржува потребните карактеристики на воздухот во сите сезони. Иако овој систем е скап сепак ќе придонесе за оддржување на соодветна температура, влажност и слични параметри на воздухот и ќе ја зголеми продуктивноста на вработените.

Како последен чекор во планирањето на ентериерот на канцеларискиот простор претставува контролата на звукот. Контролата на звукот може да биде на соодветно ниво доколку се елиминира дел или целосно изворот на звукот. Како извор на звук се јавува бучавата од сообраќајот, други надворешни звуци, отворање на врати и прозорци, телефонски или меѓусебен разговор на вработените и слично. 
Анализа на концептите на организација и опремување со мебел кај канцелариските простори магистерски труд Зејнелабедин Азири

Контролата на звукот од надворешните извори е контролирана преку поставување на бетон и прозорци во објектот. Додека контролата на звукот од внатрешните извори може да се постигне преку првично детектирање на изворот на звук (телефонски разговор, отворање на врата и слично) и потоа преку поставување на дополнителен материјал за изолација, доколку има потреба кај некои простории, или преку менување на распоредот на елементите и слични методи. ${ }^{30}$ При дизајнирање на ентериерот и поставување на елементите од мебелот почесто ќ се врши мерење на јачината на звукот со цел да се детектира и лоцира евентуалната неповолна јачина на звук и истата да се елиминира.

\subsection{3 Опремување со мебел на канцеларискиот простор наменет за новинската агенција}

Опремувањето и декорацијата на канцеларискиот простор се состои во избор на соодветен дизајн каде материјалот и завршницата на елементите за опремување се восогласност со проектот за ентериерот. Елементите мебел кои најчесто се применуваат во опремување на канцелариските простори се: движен мебел, недвижен мебел, вградени елементи, работни бироа, канцелариски бироа, маси за состаноци, мебел за седење (столови, полуфотељи, фотељи, софи) и електронска опрема (компјутери, принтери, телефони, фотокопири). При определувањето на мебелот едновремено се размислува за подот и внатрешните прегради помеѓу функционално диферентните простори.

На крајот од оваа анализа ќе треба да се постигнат следниве резултати

- Ефективно изведување на работата

- Ефикасно искористување на канцеларискиот простор

- Атрактивен канцелариски простор

- Издржливи и лесно оддржливи елементи на мебел за опремување

- Елементи на мебел комфорни за управување и

- Предмер - пресметка за висната на чинење на ентериерот и опремата.

Најпрвин ќе се направи опремување и декорација на просторот одделен за генералниот уредник. Бидејќи генералниот уредник врши читање или подготовка на одреден материјал, и има средби со останатите вработени, како елементи за опремување на просторот одделен за него се избрани една ротирачка фотеља, едно биро опремено со фиоки, еден плакар и мала маса покрај бирото со две ротирачки столици.Покрај овие елементи исто така има е една маса со четири ротирачки столици. Големинатана бирото е 2,ом. должинаи 3,ом. широчина. На овој начин, со оваа димензија ќе може лесно да се смести во просторот одделен за генералниот уредник и исто така димензиите се соодветни за ефикасно искористување на просторот на бирото. Од едната страна на бирото има плакар на ниво на бирото за чување на документација. Конструкцијата на бирото е од метал додека масата е од дрво. Горната површина на масата е изведена од иверка со д=25мм. фурнирана со ламинат во завршница на тиково дрво. Столот кој е избран е ротирачки со тркала и со потпирач за рацете.

\footnotetext{
${ }^{30}$ Robichaud Beryl-Selecting Planning and Managing Office Space
} 
Просторот наменет за лицето за односи со јавност е опремен со една ротирачка фотеља, едно биро со мала маса како додаток од едната страна, два плакари, и две ротирачки столици со мала маса лоцирани покрај бирото.

Конструкцијата на бирото е од метал додека масата е од дрво.Горната површина на масата е изведена од иверка со д=25Мм. фурнирана со ламинат во завршница на тиково дрво. Столот кој што е избран е ротирачки со тркала и со потпирач за рацете. Покрај ова во просторот има и две комоди со различна димензија соодветно на намената (75цм. ш. $\mathrm{x}$ 115цм. в./8оцм. ш. х 75цм. в.

Просторот одделен за секретарот ќе биде опремен со едно биро, еден стол за седење и еден плакар. Конструкцијата на бирото е направена од метал додека масата е изведена од иверка со д=25Мм. фурнирана со ламинат во завршница на тиково дрво.

Просторот наменет за новинарите е опремен со биро и стол за секој новинар посебно. Изгледот заедно со димензиите на бирото наменет за секој новинар е прикажан во Цртеж.17. Конструкцијата на бирото е од метал додека масата е изведена од иверка со д=25мм. фурнирана со ламинат во завршница на тиково дрво.

Конференциската сала е опремена со една голема маса чии димензии се 3,8 метри должина и 1,5 метри широчина опремена со 12 столици. Конструкцијата на масата е од метал и дрво додекагорната површина на масата е изведена од иверка со д=25мм. фурнирана со ламинат во завршница на тиково дрво.

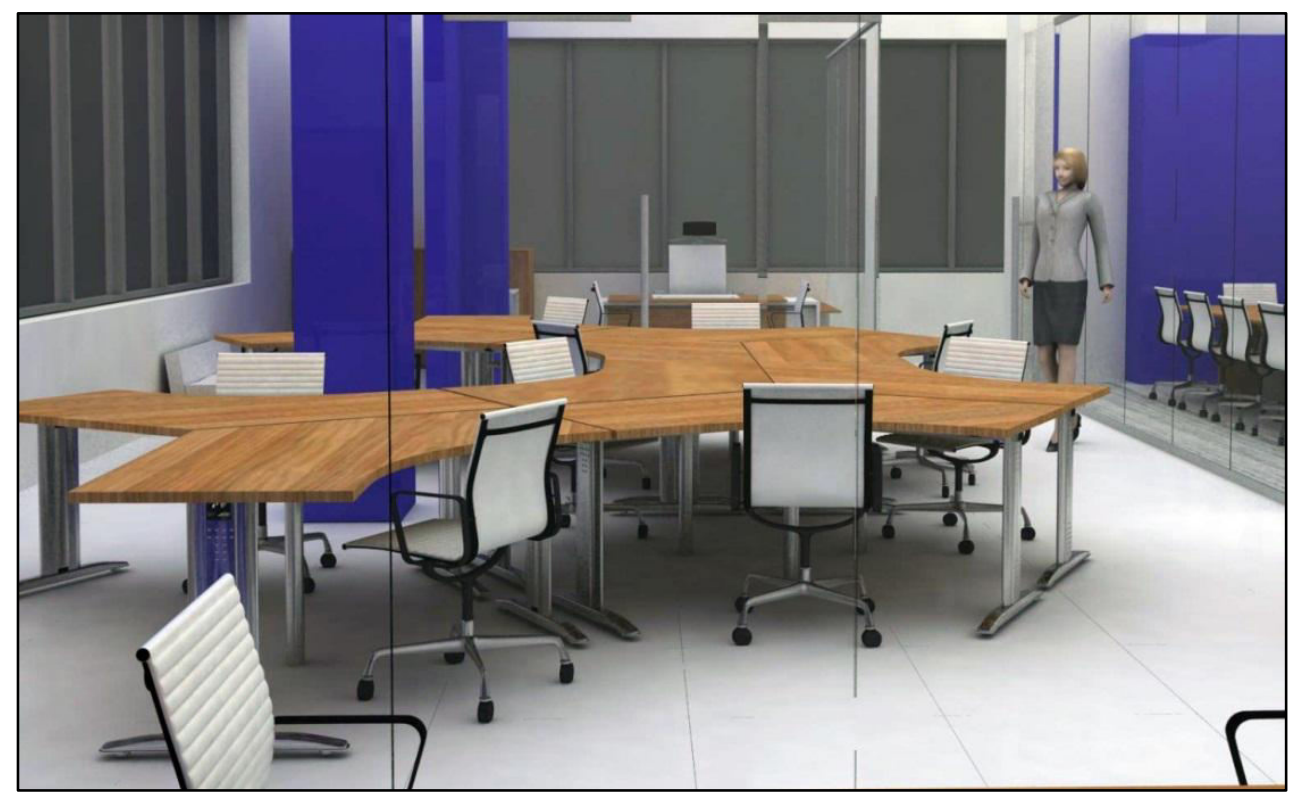

Цртеж.17Поглед кон просторот за новинари во канцеларискиот простор кај новинската агенција

Во Цртеж.9,Цртеж.10и Цртеж.11 претставени се цртежи на канцеларискиот простор на новинската агенција. 
Анализа на концептите на организација и опремување со мебел кај канцелариските простори магистерски труд Зејнелабедин Азири

\section{2 Анализа на проектот за ентериерот на канцеларискиот простор за правна канцеларија}

Местоположбата на правната канцеларија е иста како и местоположбата на новинската агенција, ДТц Мавровка.

\subsection{1 Проценка на големината на потребниот простор за правна канцеларија}

За уредување на правната канцеларија е земен во предвид истиот простор со идентична форма, димензии и површина како и канцеларискиот простор кај новинската агенција. Димензиите на просторот се прикажани во Цртеж.18.

Правната канцеларија, која е предмет на анлиза во овој сегмент од трудот, вработува 8 луѓe, кои што се подделени според следниве функции:

- 4 адвокати

- 1 нотар

- 1 помошник на нотарот

- 1 секретар

- 1 лице за оддржување на просторот

Просторот во правната канцеларија е од затворен тип. Предностите на овој вид на канцелариски простор се контролиран простор, безбедност, визуелна приватност и физичко одделување. Овие карактеристики на просторот се најсоодветни за правната канцеларија покрај недостатоците кој што овој вид на простор ги има како што се помалку ефикасен во однос на отворен тип на простор, потреба од флексибилност, трошоци за преместување и спречување на комуникација.

Како прв чекор кој што ќе се спроведе е одредување на тип на простор, отворен или затворен, за секој вработен одделно.

- Активностите на адвокатите повеќе се основаат на читање на одреден материјал и средби со лица кои што доаѓаат надвор од компанијата. Притоа адвокатите имаат потреба од голем но затворен канцелариски простор. Затворениот простор ќе му овозможи на адвокатот да биде заштитен од визуелно и звучно вознемирување од останатите адвокати и нотарот кои што се наоѓаат во останатиот дел од канцеларискиот простор како и од нивниот разговор. 


\section{Правна Канцеларија}

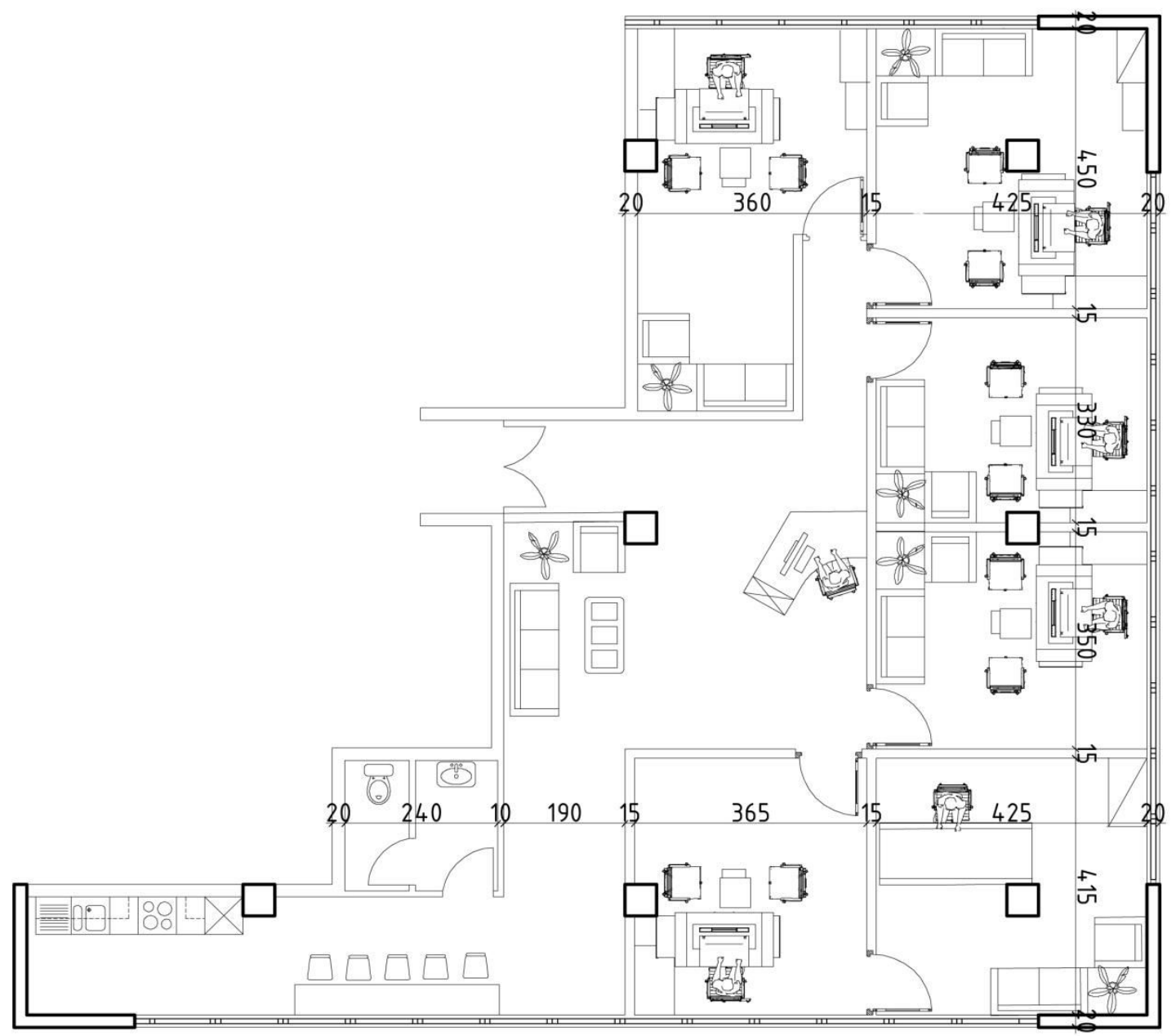

Основа

$\mathrm{M}=1: 100$

Цртеж.18Ентериер на просторот од правната канцеларија опремена со мебел 


\section{Правна Канцеларија}

\section{ЛЕГЕНДА}

01 Адвокатска канцеларија

02 нотар

03 Помошник на нотар

04 Секретар

05 Кујна со трпезарија

06 чекална

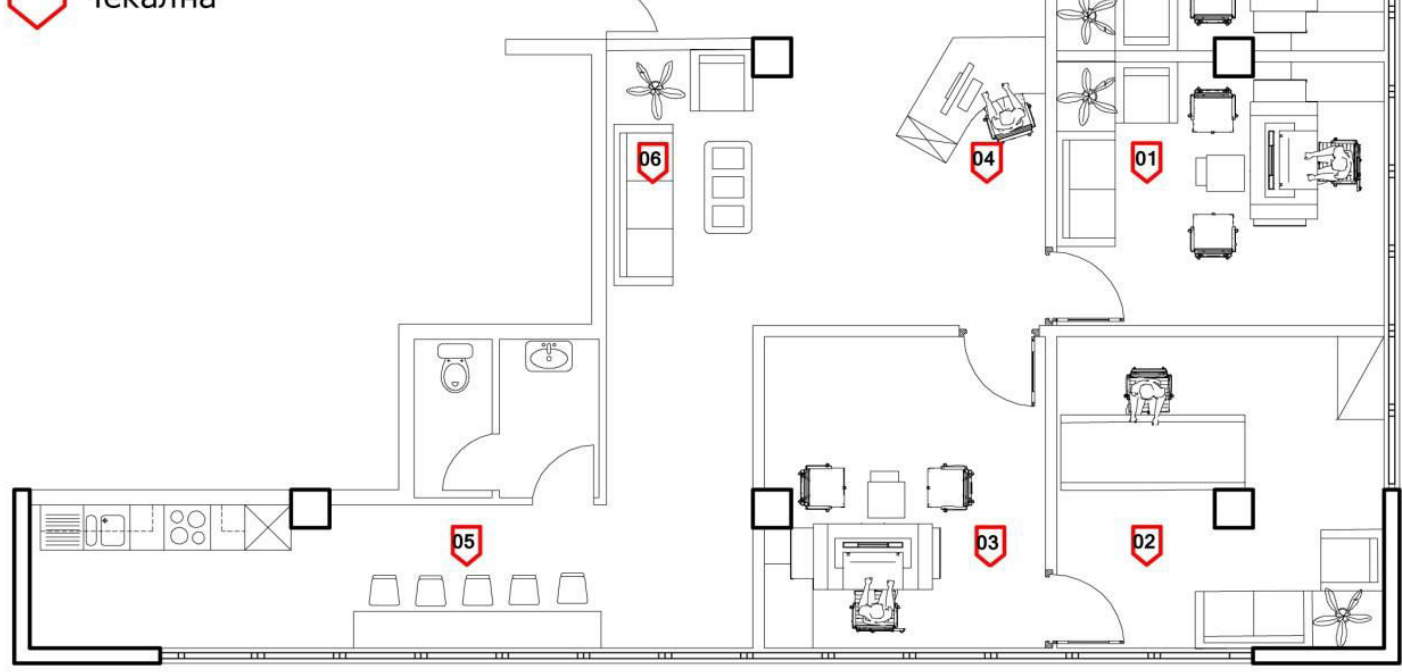

\section{Основа $\mathrm{M}=1: 100$}

Цртеж.19 Просторот во правната канцеларија функционална поделба и опремување со мебел 


\section{Правна Канцеларија}

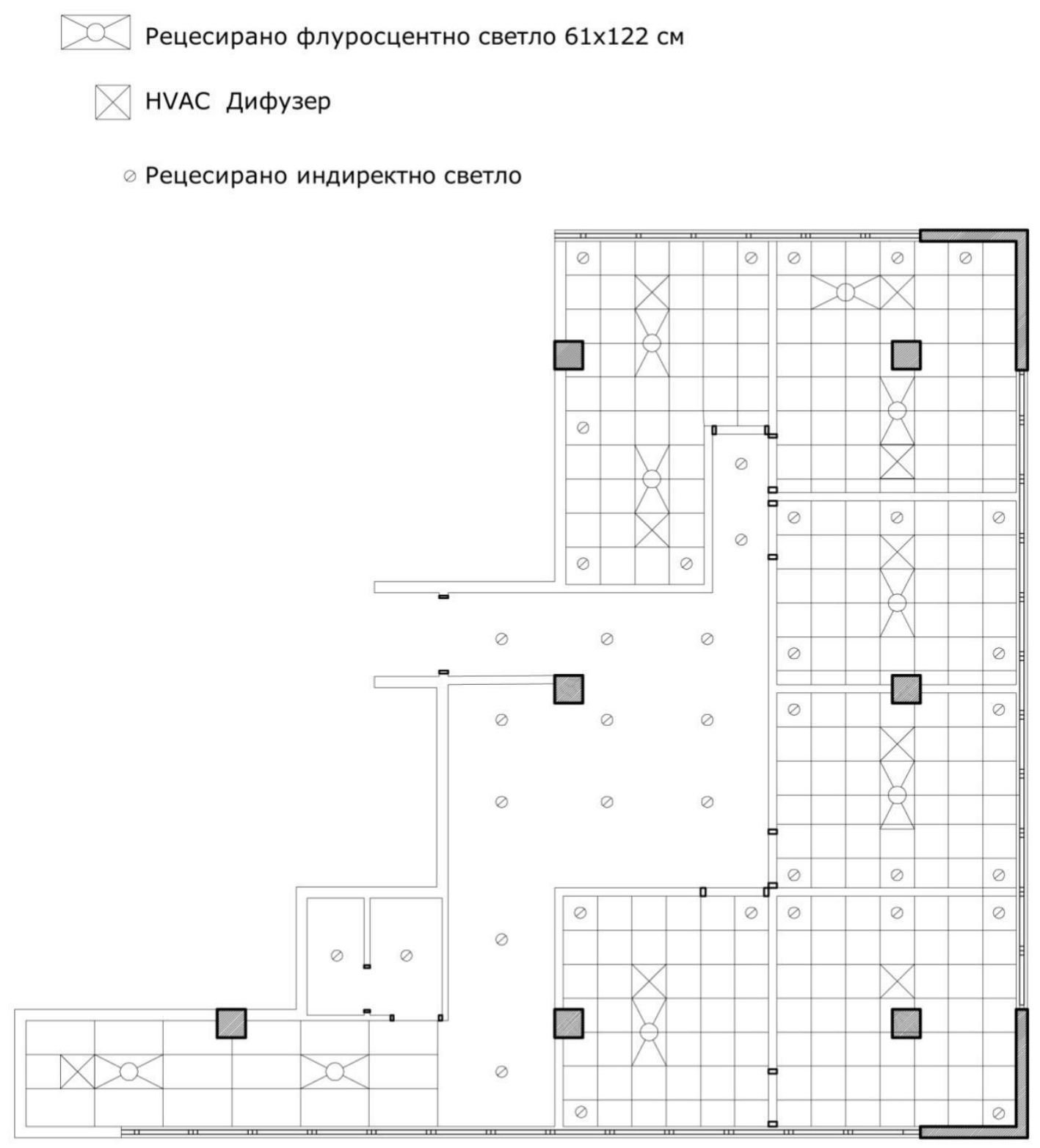

Основа на спуштена таваница кај ентериерот на правната канцеларија $\mathrm{M}=1: 100$

Цртеж.2оОснова на спуштена таваница во правната канцеларија 
Анализа на концептите на организација и опремување со мебел кај канцелариските простори магистерски труд Зејнелабедин Азири

Одредени активности кои адвокатот ги извршува не би требало да бидат предмет на следење од страна на останатите лица (на пример, разговор со клиент). На крај, овој простор автоматски му доделува статус на приватност, кој пред се адвокатот има потреба бидејќ́ работи со документација и случаи кои се од приватна природа.

- Активностите на нотарот почесто се основаат на заверување на документација на клиентите како и нивно консултирање доколку тоа е потребно. Притоа нотарот заедно со својот помошник имаат потреба од затворен простор заштитен со непрозирен материјал. На овој начин, тие ќе бидат визуелно но и звучно заштитени од останатите лица кои што се наоѓаат во канцеларискиот простор, бидејќи клиентите не би сакале некој друг од страна да го слушне разговорот кој тие го водат со нотарот.

- Активностите на секретарот повеќе се основаат на разговор со лицата вработени во правната канцеларија и со лицата кои што доаѓаат надвор од канцеларијата. Притоа има потреба од отворен простор кој не е заштитен со материјал и истиот е лоциран во близина на влезот на кацеларијата. на овој начин секретарот ќе биде во директна комуникација со останатите вработени во канцеларијата и исто така ќе биде прво лице за контакт за оние лица кои што доаѓаат од надвор.

- Активностите на лицето за оддржување на канцеларискиот простор почесто се основаат на послужување на вработените или гостите со одреден пијалок или храна и хигиенско оддржување на просторот. Притоа лицето за оддржување на канцеларискиот простор има потреба од затворен простор каде што би бил сместен потребниот инвентар за соодветно спроведување на обврските.

Како што може да се увиди во правната канцеларија просторот одделен за вработените е затворен додека за споредба кај новинската агенција каде што просторот делумно е затворен (кај генералниот уредник и кај лицето за односи со јавност) и делумно отворен за новинарите. Оваа разлика настанува од природата на работата која што се врши во секој субјект засебно. Кај правната канцеларија вработените имаат потреба од затворен простор со цел да се има поголема приватност додека кај новинската агенција новинарите имаат потреба од отворен простор со цел полесна комуникација. Оттука може да се увиди дека кога се работи за субјекти со различна активност доаѓа и до разлика и во дизајнот на просторот.

Откако е направена одлука за видот на просторот одделен за секој вработен, затворен или отворен, следен чекор е да се одреди големината на секој одделен простор.

Просторот кој што е одделен за адвокатите се менува од 14 метри квадратни до 20 метри квадратни. Големината на овој простор е во рамките на предложените светски стандарди. ${ }^{31}$ Согласно стандардот, овој простор е доволен за лоцирање на едно биро, два плакари и две столици. Во Цртеж.21, претставени се основа и пресек со аксонометриска престава на просторијата за адвокат кај правната канцеларија.

Големината на просторот одделен за секретарот изнесува 4,5 метри квадратни (3

\footnotetext{
${ }^{31}$ Robichaud Beryl-Selecting Planning and Managing Office Space.
} 
метри х 1,5 метри). Оваа големина ќе биде доволна за лоцирање на бирото кое што ќе биде користено од страна на секретарот како и столот на кој што ќе седи. Исто така, овозможен е простор за слободно движење.

Просторот кој што е одделен за нотарот заедно со неговиот помошник е со првична големина од 33 метри квадратни (7,9 метри х 4 метри). Големината на овој простор е во рамките на предложените светски стандарди. ${ }^{32}$ Согласно стандардот, овој простор е доволен за лоцирање на две бироа, два плакари и две столици. Во Цртеж.22, претставени се основа и пресек со аксонометриска престава на просторијата за нотар кај правната канцеларија.

Следен чекор во одредувањето на потребниот канцелариски простор е да се одреди потребната големина на помошните простории. Помошните простории кои што се потребни за правната канцеларија се простор за чекање, кујнски простор и еден тоалет со посебна соба со мијалник.

Големината на просторот кој што е одделен за чекање изнесува 6,7 метри квадратни (2 метри х 3,5 метри). Овој простор ќе биде опремен со еден кауч за седење.

\footnotetext{
${ }^{32}$ Robichaud Beryl-Selecting Planning and Managing Office Space.
} 

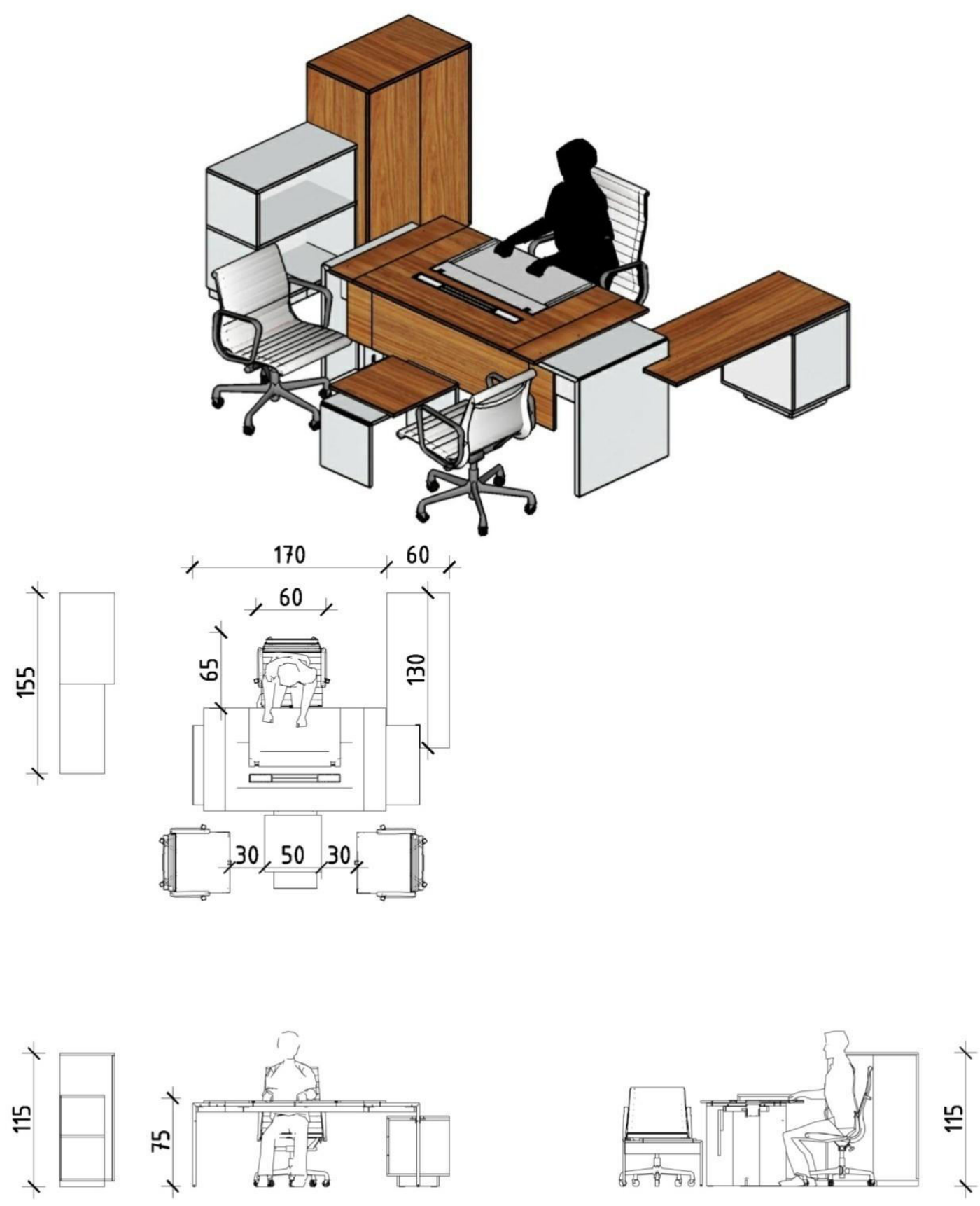

ОСНОВА И ПРЕСЕК СО АКСОНОМЕТРИСКА ПРЕСТАВА НА КАНЦЕЛАРИЈА НА АДВОКАТ $M=1: 50$

Цртеж.21Основа и пресек со аксонометриска престава на просторијата за адвокат кај правната канцеларија 

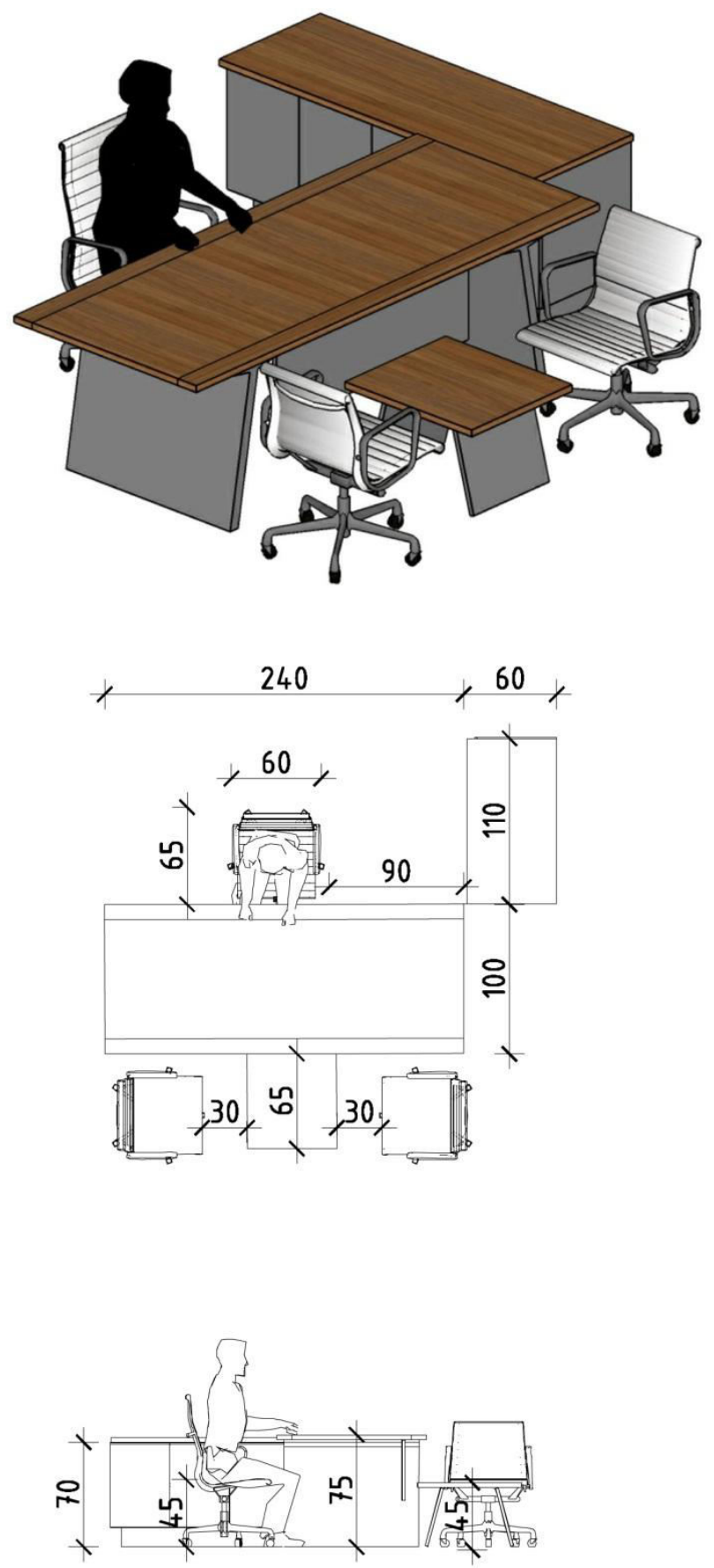

ОСНОВА И ПРЕСЕК СО АКСОНОМЕТРИСКА ПРЕСТАВА НА КАНЦЕЛАРИЈА ЗА НОТАР $M=1: 50$

Цртеж.22 Основа и пресек со аксонометриска престава на просторијата за нотар кај правната канцеларија 
Анализа на концептите на организација и опремување со мебел кај канцелариските простори магистерски труд Зејнелабедин Азири

Кујнскиот простор е со големина од 8метри квадратни (4,2 метри х 1,85 метри). Во овој простор ќе има можност да се лоцира фрижидер, шпорет и мијалник за садови. Искористен е дополнителен простор за маса и столици за јадење.

Просторот кој што е одделен за тоалетот е со големина од 6,2 метри квадратни (2,3 метри х 2,7 метри). Овој простор ќе биде поделен во два дела од кој едниот има само мијалник додека другиот простор има само тоалет школка. Големината на овој простор е во согласност на предложените димензии за тоалет.5,6

\subsection{2 Планирање на ентериерот на канцеларискиот простор на правна канцеларија}

Планирањето на канцеларискиот ентериер за правната канцеларија започнува преку согледување на структурата на објектот. Внатрешните носечки столбови во канцеларискиот простор се оддалечени едни од други во должина од околу 5 метри.

Во однос на висината на таванот, се цел поудобен ентериер, пожелно е висината да биде поголема од 8 стапки (2,4 метри).

Следен чекор при планирањето на канцеларискиот ентериер е да се согледаат sидовите или преградите кои што ќе се користат за одделување на специјален простор за одредени вработени. Во правната канцеларија, само просторот наменет за секретарот е од отворен вид додека кај адвокатите и нотарот заедно со неговиот помошник просторот е од затворен тип. Материјалот кој што е избран за преградување на овие простори е гипс картон.

Сите овие прегради ќе бидат на висина од таванот. На овој начин, лицето/лицата во преградениот простор ќ бидат целосно физички изолирани и нема да бидат вознемирувани од звуците кои што доаѓаат надвор од канцеларијата.

Просторот за тоалет ќе биде преграден со мидан sид.

Следен фактор на кој во трудот се обрнува внимание е осветлувањето. И во правната канцеларија потребна количина на светло е 50 fс.33Овој стандард за количина на светлина се однесува за генерален канцелариски простор и приватни канцелариски простори. Системот за осветлување кој што е избран е со директно осветлување каде што светилките се од видот компактни флуоресцентни.

Изборот припаѓа на овој вид светилки бидејќи овој вид обезбедува три пати повеќе светлина за еден ват, има шест пати подолг рок на траење и испушта помалку топлина во однос на инкандесцентната сијалица. Овој систем за осветлување е вграден во таванот и како материјал за заштита ќе се користи пластиката.

Следен чекор при планирањето на ентериерот е избор на покривката на подот. За просторот одделен за адвокатите и нотарот заедно со неговиот помошник подот ке биде покриен со ќилим од волна поради комфорот што го нуди овој материјал при одење како и неговиот атрактивен изглед. Естетиката на правните канцелариски простори би требала

\footnotetext{
${ }^{33}$ Robichaud Beryl-Selecting Planning and Managing Office Space.
} 
Анализа на концептите на организација и опремување со мебел кај канцелариските простори магистерски труд Зејнелабедин Азири

да емитува сигурност, постојаност, сериозност и строгост. На овие елемнети би требало да се обрне внимание при изработката на овој ентериер, поради природата на работата во нив, како и поради фактот што сите активности се поврзани со директен контакт со клиентите. Затоа, за да се понуди најдобра можна услуга потребно е соодветно дизајнирање на просторот. Од оваа причина подот и кај остантиот дел од просторот е покриен со ќилим од волна со цел да се понуди удобност на клиентите како и атрактивен изглед. Подот кај тоалетот и кујната ќе биде покриен со кеармички плочки со цел негово полесно оддржување.Со цел да се обезбеди соодветна температура, влажност, свежина, чистота и циркулација на воздухот во канцеларискиот простор потребно е да се има систем за вентилација. системот за вентилација кој што ќе се користи во правната канцеларија е централен систем за вентилација.

Овој вид на систем ќе биде во можност да ги одржува потребните карактеристики на воздухот во сите сезони. Иако овој систем е скап сепак ќе придонесе за оддржување на соодветна температура, влажност и слични параметри на воздухот и ќе ја зголеми продуктивноста на вработените. Исто така, уште еднаш треба да се наведе дека на овој начин ќе се понудат подобри услови за клиентите кои што ги користат услугите на канцеларијата.

Како и кај новинската агенција, последен чекор во планирањето на ентериерот на канцеларискиот простор претставува контролата на звукот. Контролата на звукот може да биде на соодветно ниво доколку се елиминира дел или целосно изворот на звукот. Како извор на звук се јавува бучавата од сообраќајот, други надворешни звуци, отворање на врати и прозорци, телефонски или меѓусебен разговор на вработените и слично. Контролата на звукот од надворешните извори е контролирана преку поставување на бетон и прозорци во објектот.Додека контролата на звукот од внатрешните извори може да се постигне преку првично детектирање на изворот на звук (телефонски разговор, отворање на врата и слично) и потоа преку поставување на дополнителен материјал за изолација, доколку има потреба кај некои простории, или преку менување на распоредот на елементите и слични методи. При дизајнирање на ентериерот и поставување на елементите почесто ќе се врши мерење на јачината на звукот со цел да се детектира непосакувана јачина на звук и истата да се елиминира.

\subsection{3 Опремување на канцеларискиот простор на правна канцеларија со мебел}

Опремувањето и декорацијата на канцеларискиот простор се состои од избор на дизајнот и бојата на елементите за опремување (столици, маси и сл.), подот и преградите.

На крајот од оваа анализа ќе треба да се постигнат следниве резултати

- Ефективно изведување на работата

- Ефикасно искористување на канцеларискиот простор

- Атрактивен канцелариски простор

- Издржливи и лесно оддржливи елементи за опремување

- Елементи комфорни за управување и

- предмер пресметка и информација за висината на чинење на ентериерот и 
опремата.

Најнапред ќе се направи опремување и декорација на просторот одделен за адвокатите. Бидејќи адвокатот врши читање или подготовка на одреден материјал и исто така има средби со клиенти, како елементи за опремување на просторот одделен за него се избрани една ротирачка фотеља, едно биро, плакари, две ротирачки столици за гости со една мала маса. Покрај овие елементи кај секој адвокат има една фотеља и кауч кои се сместени во аголот на канцеларискиот простор. Овие елемнти ќе му овомзожат на адвокатот да ги изведува своите обврски.

Просторот наменет за нотарот е опремен со една ротирачка фотеља, едно биро, еден плакар, и две ротирачки столици со мала маса. Просторот кај помошникот на нотарот е опремен со ротирачки стол, едно биро, плакар, две ротирачки столици покрај бирото и мала маса.

Просторот одделен за секретарот ќе биде опремен со едно биро, еден стол за седење и еден плакар. Конструкцијата на бирото е направена од метал додека масата е од дрво со финитура на дрво.

Изгледот на правната канцеларија е прикажан во Цртеж.18, Цртеж.19 и Цртеж.20 


\section{4. Анализа на антропометријските и ергономските параметри применети во опремување на ентериерите за работа со канцеларијска опрема}

Разработени се два различни пристапи, наменети за две различни деловни структури и субјекти. Компаративниот пристап за два функционално дивергентни концепта овозможува појасен увид во барањата, можностите и капацитетите на објектот за секоја од конкретните намени. Преку проектните анализи потенцијалните корисниците на канцеларискиот простор би имале детален преглед и сознанија за постапките на планирање и проектирање на конкретниот простор. Распоредот на мебелот и останатото уредување варираат во двете варијанти создадени за нив и во многу зависат од анализите на антропометриските и ергономските принципи на проектирање применети во анализата.

Во овој сегмент од трудот ќе биде направен обид за анализа на ергономските 34 и антропометриските 35 карактеристики кои го детерминираат седењето и работењето на работното место. Тие параметри се појдовен елемент од кој се тргнува при дизајнирањето на мебелот за опремување на канцеларискте простори.

Со векови работењето на луѓето се одвивало во стоечка позиција. Менувањето на моделот на работа (зголемување на работењето со документација), развојот на индустриските технологии (автоматизација и сл.) и промената во начинот на рекреација (ТВ) го зголемуваат времето кое луѓето го поминуваат во седење. Паралелно со овие промени почна истражувањето на ергономијата на седење. Од доцните четириесетти имало многу обиди да се формулираат оптималните потреби при седењето. Овие потреби обично биле засновани на концептот за физиолошка удобност на корисникот. Со други зборови, како да се дизајнира столот така што би се постигнала поголема физиолошка удобност. ${ }^{36}$

Целта на седењето е да се обезбеди стабилна поддршка на телото во позиција која што е:37

1) Комфорна низ одреден период;

2) Физиолошки задоволителна;

3) Соодветна на задачата и активноста која што се изведува;

Сите столици се некомфорни кога во нив минуваме подолг период од денот, но некои стануваат некомфорни многу побрзо отколку некои други. Исто така, на некоја одреден стол неколку луѓе би се чуствувале повеќе некомфорно отколку други луѓе. Комфорот

\footnotetext{
${ }^{34}$ Зборот ергономија потекнува од грчкиот јазик, ergos, работа ипотоs, природен закон. Ергономијата е наука која го истражува взаемниот односм помеѓу човекот и употребуваниот предмет/објект и начинот на кој истата се изведува. Исто така, ги анализира алатките и опремата која што се користи и местото каде што работат и психосоциолошките аспекти на работната околина.Со други зборови ергономијата е наука на согласување на работата со работникот и на производот со корисникот.

${ }^{35}$ Антропометријата е гранка на науките за човекот која што се занимава со димензиите на човековото телото,формата, јачината и работниот капацитет.Антропометријата е многу важна гранка на ергономијата.

${ }^{36}$ Mehmet A. Postural and Physiological Criteria for Seating- A Review METU,Journal of the of Architecture v.1 n.1 Spring 1975

${ }^{37}$ Stephen Pheasant, Anthropometry, Ergonomics and the Design of Work, Taylor \& Francis, 2003
} 
Анализа на концептите на организација и опремување со мебел кај канцелариските простори магистерски труд Зејнелабедин Азири

исто така може да биде зависен и од задачата или активноста која што се извршува. Со други зборови комфорот ќ зависи од интеракцијата помеѓу карактеристиките на седиштето, корисникот и задачата. 38

Положбата обично се дефинира како положба на телото, главата и екстремитетите во однос едни со други. Тоа може да се изрази со аглите под кои се наоѓаат сврзните ткива на телото. Влијанието на една положба може да се одреди со степенот под кој го оптеретува скелетот и скелетните и/или мускулите постигнувања на таа положба. Ефектите од погрешните положби за седење се покажуваат преку искривување на 'рбетотипреморувањена мускулите на грбот. Според тоа, во положбата седење на стол, најмногу внимание се обрнува на 'рбетот, пелвисотодноснокарлицатаифемуротодноснобутнатакоскакакоделовиодскелетотивратот, грботистомачнитегрупикакомускулатураштосеактивирапри таа положба.

'Рбетот е полуфлексибилно сврзно ткиво помеѓу двата екстремитети на телото. Освен што игра огромна улога во исправеното стоење, има и витална функција за чување на 'рбетниотмозоккојевториотнајваженнервенцентарвотелото. 'Рбетотсе состои од 33 'рбетнипрешлени, Слика.9. Од нив најгорните 7 се викаат cervical vertebrae или вратни пршлени, следните 12 ce thoracic vertebrae или градни пршлени, а следните 5 се викаат lumbar vertebrae или. Од останатите 9 пршлени, 5 се споени и се викаат sacrum или сакрмум (кај нас попознат и како крст), додека последните 4 се соссух или опашка. Тоа се исто така и имињата што ги одбележуваат петте делови на целиот столб.

Првиот вратен пршлен (атлас) воспоставува контакт со главата (односно черепот). Сакрумот е прицврстен за бутната коска со силно мускулно и лигаментално ткиво за да ја создаде карлицата. Тоа е од значителна важност кај положбата за седење.

Заради градниот кош, градните пршлени не можат многу да мрдаат. Според тоа, движењата на телото се остваруваат најмногу со движењата во вратните или лумбалните пршлени.На прв поглед, 'рбетотпокажуваформирањенаправалинија. Тоаправилововратнитеилумбалнитеобластикакоикифоза (грбавост) вообластанаградниоткош. Лордозаеискривувањенанадвор (наназад) додекакифозае спротивно од тоа, тоа е искривување навнатре. Додека одредени промени во овие искривувања се природни и неизбежни во текот на движењето на телото, нивните екстремни менувања предизвикуваат сериозни нарушувања на здравјето. Кога природното искривување на столбот се менува, еднаквиот притисок меѓу дисковите на прешлените стануваа нееднаков, Слика.9,и предизвикуваат одредени изместувања на дисковите што резултираат со краткорочна болка и долгорочно изместување на дисковите.

Лумбалниот дел е обично делот од 'рбетот кој трпи најмногу товар. Лумбалната лордоза може да се зголемува или намалува.

\footnotetext{
${ }^{38}$ Mehmet A. Postural and Physiological Criteria for Seating- A Review METU,Journal of the of Architecture v.1 n.1 Spring 1975, Согласно трудот на проф.Мехмет Асатекин, Postural and Physiological Criteria for Seating, комфорноста при седењето зависи од тоа на кое ниво се задоволени критериумите за удобност на 'рбетот и мускулите.
} 

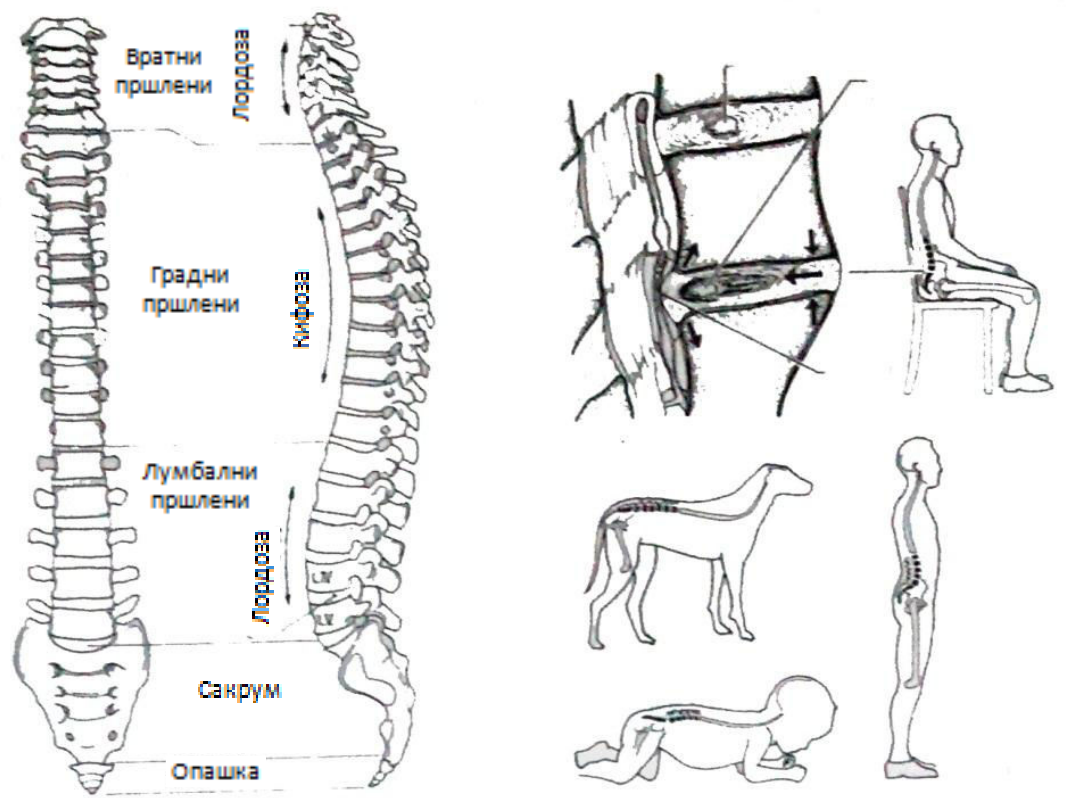

Слика.9 'Рбет и лумбала кај дете, коњ и возрасен човек

Но сепак според Киган, најприроднатаположба на лумбалната област се случува кога аголот помеѓу телото и бутот е 135 степени, Слика.10. Таа положба се добива кога се лежи странично или се седи на стол со бутовите придвижени нанапред. 39

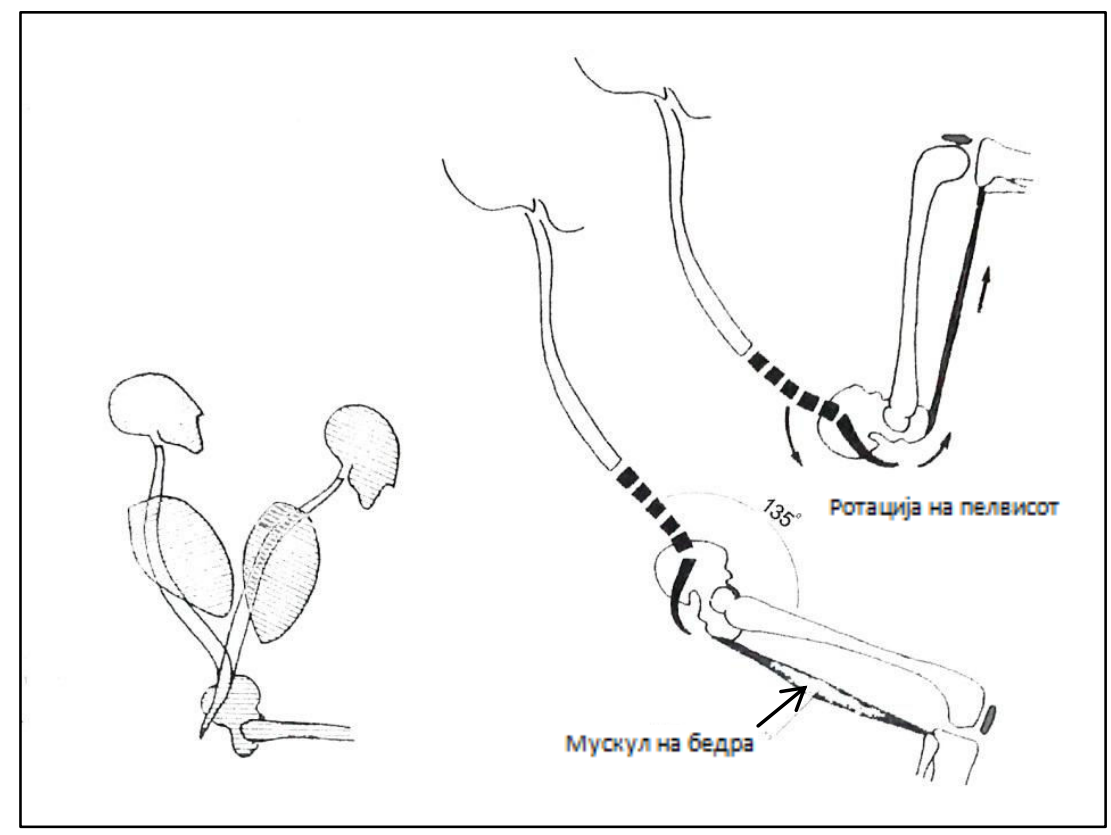

Слика.1о Промена на лумбалната лордоза

\footnotetext{
${ }^{39}$ J. J. Keegan, Alterations of the Lumbar Curve Related to Posture and Seating, Journal of Joint and Bone Surgery, v.35, n.3, 1953, pp. 589-603
} 
Зголемувањето на лумбалната лордоза се случува кога се стои.Делумно, тоа е причината поради што се јавува болка во 'рбетот кога се стои подолго време.

Од друга страна, екстремното израмнување/намалување се случува кога сме згрбавени. Всушност, во таа позиција лордозата станува кифоза. Кревањето на тежина во таа позиција создава голем притисок (понекогаш 10 до 15 пати поголем од подигнатата тежина) на лумбалните интервертебрални дискови. 40

Кога седиме лумбалната лордоза се намалува.За да се спречи, потребно е да се има соодветна потпора.Лумбалнта област не е единствениот дел кој е под влијаније при седење. Исто така при седење може да се забележи зголемување во градната кифоза (пагајќи нанапред). Во одржување на нормална положба на седење, положбата на телото може да покаже мали разлики. Тоа може да биде во оние што се нарекуваат предни, средни или задни положби. Овие положби зависат од локацијата на центарот на гравитација на телото и од тежината што се пренесува од стапалата на подот.

Одржувањето на средната положба бара постојана изометрична напнатост, односно статична концентрацијана мускулите на грбот (карличните мускули и широките грбни мускули, Слика.11.41

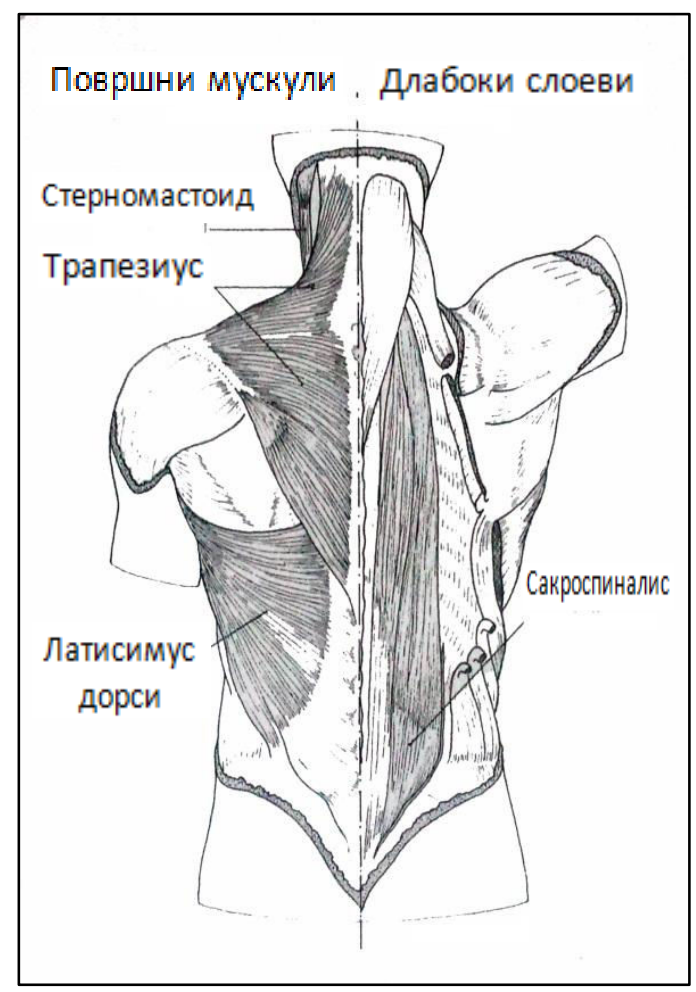

Слика.11 Задни и вратни мускули

\footnotetext{
${ }^{40}$ F.K. Bradford and R.G. Spurling, The Intervertabral Disc: With Special Reference to Rupture of the Annulus Fibrons, With Herniations of the Nucleus Pulpous, Illinois: Charles C. Thomas, 1945.

${ }^{41}$ K. H. E. Kroemer and J. C. Robinette, Ergonomics in the Design of Office Furniture, A Review of European Literature, Industrial Medicine and Surgery, v.38, n.4, 1969, pp. 115-125
} 
Анализа на концептите на организација и опремување со мебел кај канцелариските простори магистерски труд Зејнелабедин Азири

Бидејќ́ трошењето на енергија при статичната работа на мускулите е толку многу непропорционално споредено со механичката работатаквите последователни статички контракции многу изморуваат. 42

Според тоа, од гледна точка на здравјето на скелетот и мускулите, произлегуваат четири точки на кои треба особено да се внимава при дизајнирање на стол удобен за работа и седење:

- да се одржува лумбалната лордоза што е можно поголема;

- $\quad$ да се помогне во тоа спречувајќк го пелвисот да ротира наназад (со потпора на седиштето);

- одржување на позициите што ја намалуваат изометричната напнатост во задните и мускулите на вратот;

- ослободување на мускулите од нивната активност со мали промени на положбата; Физиолошката задоволителност на столотзависи од нејзиното влијание врз крвотокот, нервите, површинските ткива и размената на топлина на телото.

Влијанието на седечката положба и заемното влијание на седиштето и лицето што седи на циркулацијата на крвта на долните екстремитети се набљудуваат во промените на венозниот притисок во долните екстремитети и неговите последици како и во локалната отрпнатост заради стеснување на артериите. 43 Бидејќи притисокот на крвните садови предизвикува циркулација на крвта во нив, притисокот на нервите (не на нервните завршетоци) предизвикува ослабување на нивната работа. Таквото ослабување се манифестира како форма на отрпнатост или умртвеност во областите каде функционираат нервите. Областите кои се најподложни на претерано притискање се задните страни на бутовите и мускулната маса на задникот. Скијатичните нерви поминуваат низ овие две области.

При седење на стол, неколку делови од телото доаѓаат во контакт со површината на седиштето и нормално, притиснати се заади тежината на телото. Тоа притискање е неизбежно, но неговиот карактер и количина во голем дел се одредени од дизајнот на елементите на седиштето.

Размената на топлина помеѓу човекот и неговата околина зависи од загубата на топлина преку испарувањето (и потењето), како и со со неговата загуба и добивање на топлина со радијација и пренесување на топлина со движење на течност или гас. Телото разменува топлина со воздухот што го опкружува преку пренос и со површините што го опкружуваат со радијација на долги бранови.

\footnotetext{
${ }^{42}$ A. J. S. Lundervold, Electromyographic Investigations of Position and J. C. Robinette, Ergonomics in the Design of Office Furniture, A Review of European Literature, Industrial Medicine and Surgery, v.38, n.4, 1969, pp. 115-125

${ }^{43}$ J. A. Hanson and F. P. Jones, Heart-Rate and Small Postural Changes in Man, Ergonomics, v.13, n.4, 1970, pp. 483487
} 
Во Табела.1 претставени се детерминантите на комфор при седење9,

\begin{tabular}{|c|c|c|}
\hline $\begin{array}{l}\text { Карактеристики на } \\
\text { седиште }\end{array}$ & & $\begin{array}{l}\text { Карактеристики на } \\
\text { корисникот }\end{array}$ \\
\hline Димензии на седипте & & Димензии на телото \\
\hline Агли на седипте & & Болки на телото \\
\hline Профил на седиште & & Циркулација \\
\hline \multirow[t]{8}{*}{ Тапацирање } & & Состојба на духот \\
\hline & $\begin{array}{l}\text { Карактеристики } \\
\text { задачата }\end{array}$ & \\
\hline & Времетраење & \\
\hline & Посакуван изглед & \\
\hline & Посакувана физичка состојба & \\
\hline & -Раце & \\
\hline & -Нозе & \\
\hline & Посакувана ментална состојба & \\
\hline
\end{tabular}

Статистиката покажува дека причина за повеќето боледувања е болката на вработените кај долниот дел од 'рбетот и болката кај вратот. Административната работа, исклучувајќ́ ја тешката, физичка работа, претставува главен предизвикувач на деформации на 'рбетот. 44 Причината лежи во модерниот начин на живеење, се поголемата употреба на ИТ и интернет, така што корисниците поминуваат повеќе време на компјутерската маса било да се наоѓaат дома или на работа. Истражувањата покажуваат дека несоодветното седење, како резултат на несоодветно дизајниран мебел, е причина за 14\% од главоболките, $24 \%$ од болките на вратот и рамениците, $57 \%$ од болките на 'рбетот, 19\% од болките на долниот дел од ноезете и $2 \%$ од болките во колената и стапалата.

Статичната положба при седење, особено кога се седи на несоодветно дизајниран стол кој што нема поддршка за лумбалниот дел и има мала длабочина, предизвикува болки на вратот поради константната тензија на мускулите на рамениците и болки на 'рбетот поради зголемен притисок врз 'рбетниот диск. Малата длабочина на столот има штетни ефекти врз мускулите и врз циркулацијата на крвта и лимфната течност во нозете. Статичното седење може да предизвика стрес врз кардиоваскуларниот систем и може да има негативен ефект врз дигестивните органи. ${ }^{21}$

Набљудувањето на една личност додека седи на обичен стол со потпирач за исправен грб покажува дека по краток период личноста го лизга задникот нанапред и продолжува да седи во таа положба. Причината за тоа е дека таквиот обичен стол го стабилизира грбот така што го потпира до висина на рамената.

\footnotetext{
${ }^{44}$ Markovac, Ž.., Grbac, I. Ivelic, Ž.," Orthopaedics and orthopaedic furniture", International Conference"Ecological, biological and medical furniture - Fact and misconceptions" Zagreb Croatia, 2000, pp 75 - 82
} 


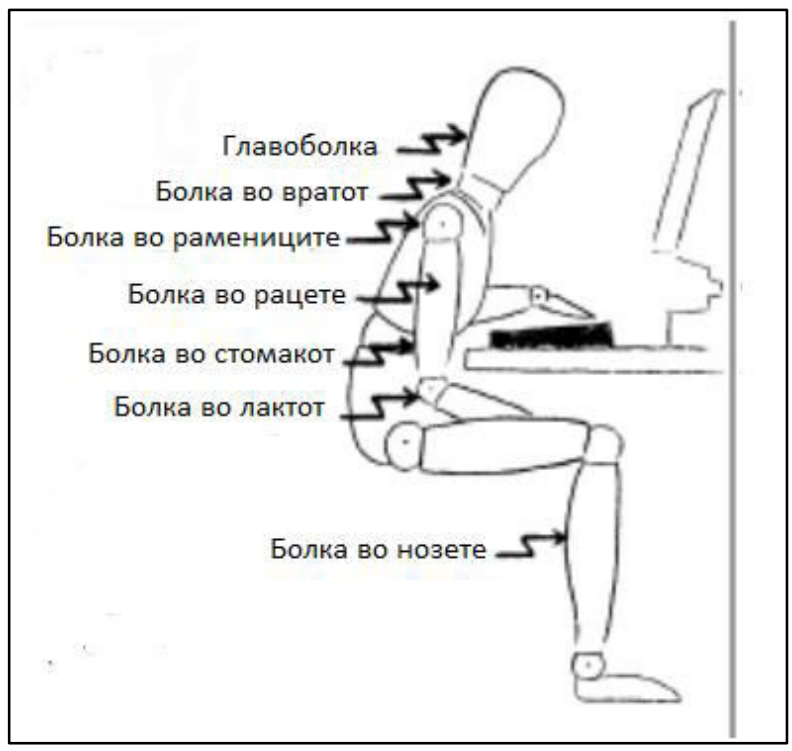

Цртеж.23Болки предизвикани од несоодветна положба при седење

Тоа слободно дозволува ротирање на пелвисот наназад и израмнување на лумбалното искривување. Освен тоа, иако дизајнот можеби се чини дека обезбедува агол од приближно 95 степени помеѓ телото и бутот, ротирањето на пелвисот и зголемената кифоза прават успешен агол помал од 90 степени на сврзното ткиво на колкот што води до неправилност во дишењето. Кога лицето го лизга задникот нанапред, тој/таа го проширува аголот помеѓу телото и бутот и со тоа го намалува ограничувањето на дишењето. Таа положба е склона кон ротирање на пелвисот дури и повеќе и за да се спречи тоа, лицето обично ги прекрстува нозете. Дури и во обичните големи удобни столчиња каде седиштето дозволува голем агол помеѓу телото и бутот не може да се спречи ротирањето на пелвисот.Чувството за удобност повеќе се должи на аголот помеѓу телото и бутот што се доближува до нормалните 135 степени на Киган како и на поголемата површина на која се потпира грбот. Покрај неефикасноста за удобност на скелетот во положбата за седење на стол, големите агли помеѓу телото и бутот (ообено кога се поголеми од $120^{\circ}$ ) не се погодни за работење и обично ја отежнуваат промената на положбата ${ }^{10}$

\section{Елементи на столот}

Димензиите на столот кои што се објаснети во следниот дел од трудот се претставени во Цртеж.24.

\section{Висина на столот (H)}

Во суштина, оптимална висина за седење од многу причини е онаа блиска до висината на колената. Но доколку оваа не може да биде достигната повеќе се препорачува висина која што е помала отколку поголема од оваа оптимална висина.45Кога седиштето е премногу високо, како претходно што забележавме, се јавува активностна мускулите за да се намали нерамнотежата предизвикана од тежината на нозете. Кога е ниско, радикално се намалува аголот помеѓ телото и бутот освен ако може да се испружат нозете нанапред

\footnotetext{
${ }^{45}$ Stephen Pheasant, Anthropometry, Ergonomics and the Design of Work, Taylor \& Francis, 2003
} 
(што не е многу пожелно во друштво и при работа). 46

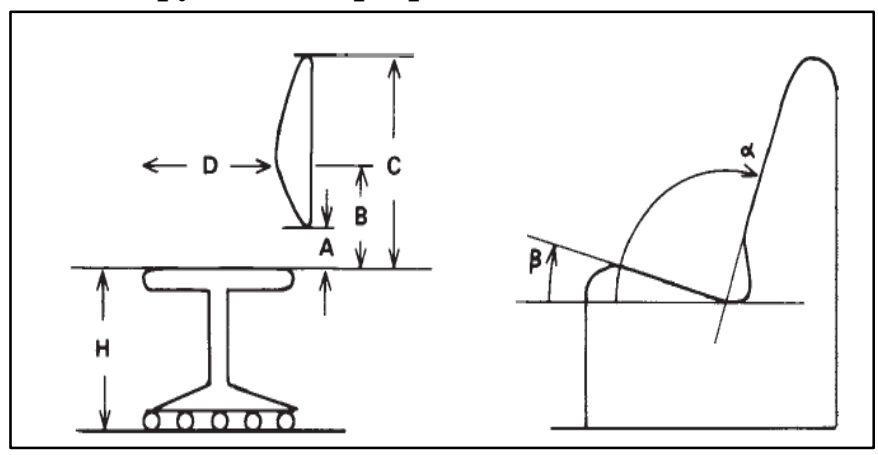

Цртеж.24 Димензии на столот

\section{Длабочина на столот (D)}

Потребно е да се запази длабочината на столот да биде онаа должина која што епомеѓу колената и задниот дел на телото. Доколку должината на длабочината е поголемаод оваа должина тогаш грбот нема да може ефективно да биде потпрен врз столот и ќе резултира со непосакуван притисок врз задниот дел на колената.

\section{Широчина на столот}

Широчина која што е помала за околу 25 милиметри од двете страни од максималната широчина на колковите е потребна. Од тоја аспект се препорачува широчина од околу 350 милиметри. Но сепак за да се остави простор за облеката во пракса минималната должина изнесува 500 милиметри.

\section{Димензии на задниот дел на столот}

Колку што е повисок задниот дел на столот, толку повеќе ќе биде ефикасен при издрживањето на тежината на телото. Предложените димензии (во милиметри) на задниот дел на столот се следниве:47

- Должина А, погледни Цртеж.20: 100-200

- Должина B:

- З За фиксен заден дел: $210 \pm 15$

- За движечки заден дел: 170-250

- Должина С-A: 200-550

Всушност, потпирачот за грбот треба да биде механички што значи треба да им помогне на лумбалните пршлени да ја создадат нивната лордоза и да го спречат ротирањето на пелвисот. Тоа може да се направи со потпирање на грбот прво и основно во лумбалната област. Таквото потпирање се вика „лумбално перниче“.Лумбалното перниче треба да биде близу до сврзното ткиво меѓу лумбалниот прешлен и сакрумот и неговата

\footnotetext{
${ }^{46}$ Mehmet A. Postural and Physiological Criteria for Seating- A Review METU,Journal of the of Architecture v.1 n.1 Spring 1975

${ }^{47}$ Stephen Pheasant, Anthropometry, Ergonomics and the Design of Work, Taylor \& Francis, 2003
} 
Анализа на концептите на организација и опремување со мебел кај канцелариските простори магистерски труд Зејнелабедин Азири

форматреба да ја потпира лордозата, односно, треба да го има испакнатиот свиок во 'рбетот. 48

Во столчињата со потпирач кои го исправуваат грбот (свиткувањето на потпирачот за грбот приближно изнесува $95^{\circ}$, минимум $93^{\circ}$ ) лумбалното перниче станува најважниот аспект од потпирачот за грбот. Таму каде што важна е подвижноста на торзото (како кај канцелариското столче) целиот потпирач за грбот може да биде само лумбално перниче. Како и да е, кога закосеноста на потпирачот за грбот е поголема од 105 степени, неопходно е да се потпре и торакалниот регион. Сепак, дури и тогаш не треба да се заборави лумбалното перниче. Центарот на лумбалното перниче обично се препорачува да биде 22 цм над површината на која се седи.49

Минимизирањето на работата на мускулите за стабилизација на телото се одразува во потребата за елемент за стабилизација на телото, воглавно, потпирач, Цртеж.2о.За таа цел, постоењето на потпирач е од суштинско значење. Од друга страна, кога ке се прифати потпирачот, неговото обликување и положбата стануваат најсуштинска точка за одржување на лумбалната лордоза и спречување на ротацијата на пелвисот.

Се кажува дека формата на 'рбетот се уникатни како и отпечатоците на прстите. Ова вклучува и варијации во кривата и должината. Должината на 'рбетот се менува до 2 цм во текот на денот. Потпирачот на грбот има критична улога во поддршката на 'рбетот и мора да се менува така што би се приспособил на овие разлики помеѓу луѓето.50

Според перформансот потпирачот го има во различни нивоа како што се:

- Фиксен потпирач-минимално ниво на перформанс: Согласно стандардите за седење,дизајнирана е крива во долниот дел од потпирачот со цел да го поддржи лумбалниот дел од 'рбетот. Овој дизајн не е соодветен бидејќи една димензија не може да биде иста за сите луѓе. ${ }^{51}$

- Потпирач кој што може да се подесува само во една оска-добро ниво на перформанс:Кривата во долниот дел од потпирачот може да се подесува најмалку во еден правец. Обично, оваа крива може да биде подесена повисоко или пониско. ${ }^{23}$ Овој дизајн претставен е во Слика.13.

- Потпирач кој може да се подесува во две оски-подобро ниво на перформанс:Кривата во долниот дел од потпирачот може да се подесува во два правци. Ова вклучува подесување на кривата повисоко или пониско и исто така подесување на нејзината длабочина.Овој дизајн исто така претставен е во Слика.12.

\footnotetext{
${ }^{48}$ Mehmet A. Postural and Physiological Criteria for Seating- A Review METU,Journal of the of Architecture v.1 n.1 Spring 1975

${ }^{49}$ AKERBLOM,B. Standing and Sitting Posture.Stocholm AB Nordiska Bokhandeln,1948

${ }^{50}$ Tyrrell, A.R.; Reilly, T.; Troup, J.D. (1985).Circadian variation instature and the effects of spinal loading. Spine 10(2), 161-164.

${ }^{51}$ The Ergonomic Seating Guide Handbook, Haworth, pp. 5-6
} 


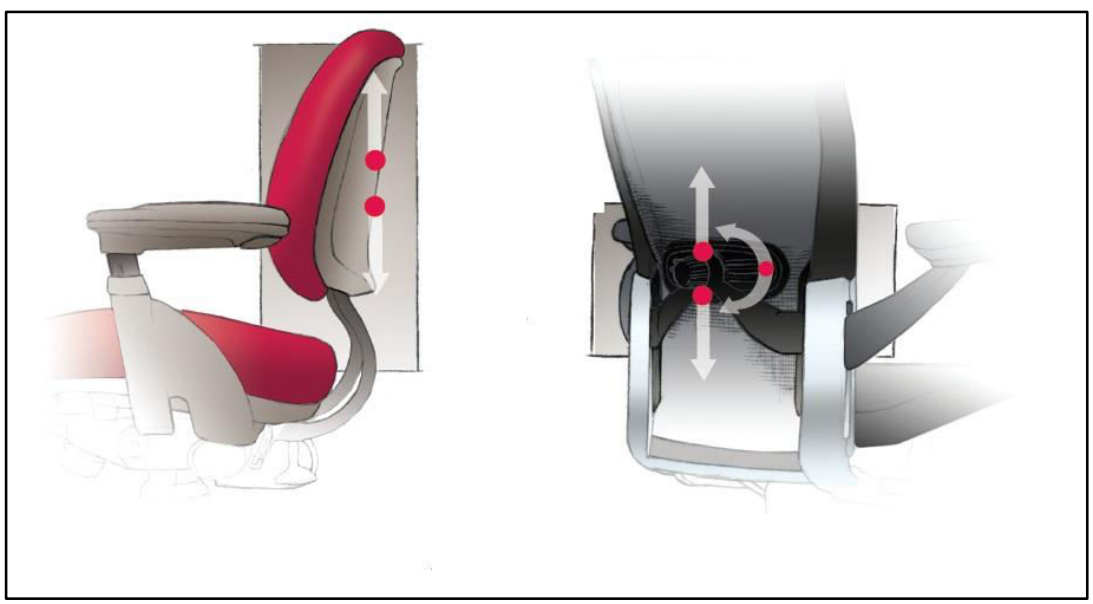

Слика.12 Потпирач со подесување во една дирекција и во две дирекции

- Потпирач кој ито може да се подесува асиметрично-најдобро ниво на перформанс: Комфорот е развиен на високо ниво со тоа што му овозможува на корисникот да ја подесува кривата повисоко или пониско и исто така да ја подесува од двете страни независно една од друга. ${ }^{2}$ Овој дизајн исто така претставен на Слика.13.

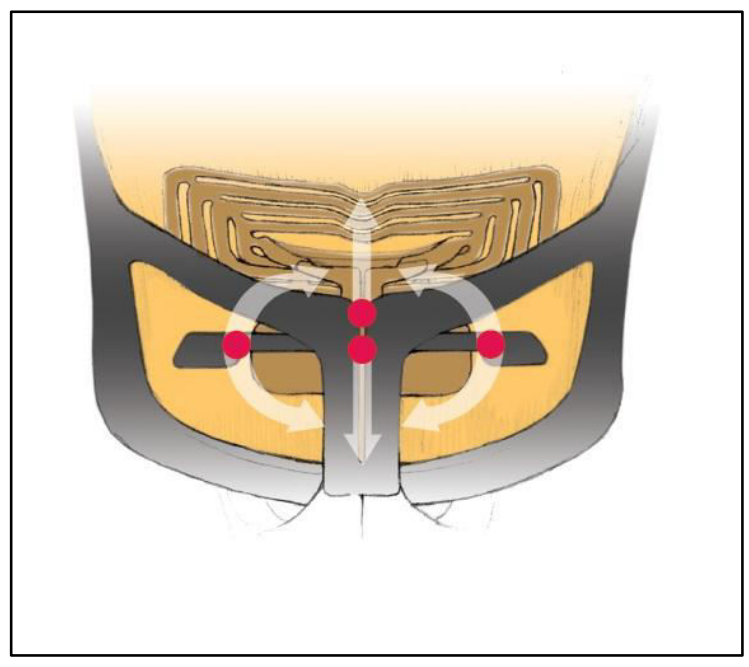

Слика.13 Потпирач со асиметрично подесување

Во сите случаи, за соодветен контакт помеѓу лумбалното перниче и лумбалната област треба да има обезбедено доволно простор за испакнувањето на сакрумот. Тоа може да се направи или со оставање на простор помеѓу површината за седење и потпирачот за грбот (упатството за понизок потпирач за грбот станува важно, обично треба да изнесува 17 цм) или со обликување на изгледот на потпирачот за да не го допира сакрумот (упатството за вертикалното свиткување на потпирачот за грбот станува важно). Сепак, поради истите причини, длабочината на седиштето треба да биде помала од должината на

\footnotetext{
${ }^{52}$ The Ergonomic Seating Guide Handbook, Haworth, pp. 5-6
} 
Анализа на концептите на организација и опремување со мебел кај канцелариските простори магистерски труд Зејнелабедин Азири

растојанието помеѓу задникот и делот зад коленото на лицето кое седи. Очигледно е дека претераната длабочина го спречува човекот да се потпре на потпирачот.53

Потпирањето на телото на потпирач дава сила на лизгање нанапред на задникот. Тоа води до грчење на мускулите на грбот, ногата и стапалото. Ослободувањето на тие мускули од активност може да се направи со создавање на толеранција на рапавост на површината на седиштето така што неусогласената сила помеѓу задникот и седиштето може да се искористи за да се спротивстави на силата на лизгањето. Во тој поглед, грубите флексибилни материјали се многу подобри од мазните тврди или флексибилни материјали за покривање на површина. Исто така, закосеноста на површината за седење малку наназад (навалување на седиштето) помага да се надмине таа сила. 54

\section{Агол на задниот дел (а)}

Како што се зголемува аголот така се зголемува и тежината која што треба да се издржи. Отималната големина на аголот е помеѓ 100 и 110 степени.

Подобро би било доколку има можност да се менува аголот на потпирачот. Со менувањето на аголот се стимулира крвотокот и се ослободува притисокот врз 'рбетот. Со само менување на аголот за 20 степени (од $90^{\circ}$ на $110^{\circ}$ ) може да се намали стресот врз 'рбетот за околу $40 \% .55$

Има различни видови на механизми кои што овозможуваат менување на аголот на задниот дел каде што секој има свои предности. Посакуваниот дизајн вклучува повеќе пивот точки. Подолу се претставени различните видови на механизми.

- Единствена пивот точка- минимум перформанс - Потпирачот се навалува околу $20^{\circ}$ во однос на делот за седење.Со овој вид на механизам, предниот дел од делот за седење често се крева притоа созадавајќи непосакуван притисок на нозете. ${ }^{56}$

- Синхронично наведнување-подобар перформанс- Движењето на делот за потпирање од столот е поврзан со делумно движење на делот за седење на столот за да се одржи соодветна поддршка на долниот дел од телото и лумбалниот дел при навалувањето. За секое навалување на делот за потпирање на столот од $2^{\circ}$ задниот дел од делот за седење се навалува за $1^{\circ}$. Со ова се минимизира кревањето на предниот дел од делот за седење и исто така ја отвора градната празнина со што се овозможува полесно дишење.

- 3-Пивот точки- најдобар перформанс- Овој синхронизиран стил на механизам ги поседува сите бенефити на синхронизираното навалување и дополнително му овозможува на корисникот штимање со цел да ја пронајде повеќе комфорната положба. Исто така овозможува подлабоко навалување на делот за потпирање со понатамошно намалување на стресот врз грбот додека се одржува

\footnotetext{
${ }^{53}$ Mehmet A. Postural and Physiological Criteria for Seating- A Review METU,Journal of the of Architecture v.1 n.1 Spring 1975

${ }^{54}$ Stephen Pheasant, Anthropometry, Ergonomics and the Design of Work, Taylor \& Francis, 2003

${ }^{55}{ }_{25}$ Chaffin, D.; Andersson, G.; \& Martin, B.J. (1999). OccupationalBiomechanics, New York: John Wiley \& Sons, 366370.

${ }_{56}{ }_{23}$ The Ergonomic Seating Guide Handbook, Haworth, pp. 10
} 
ефективна подршка на лумбалниот дел и нозете. 57 Сите три механизми се прикажани на Слика.14.

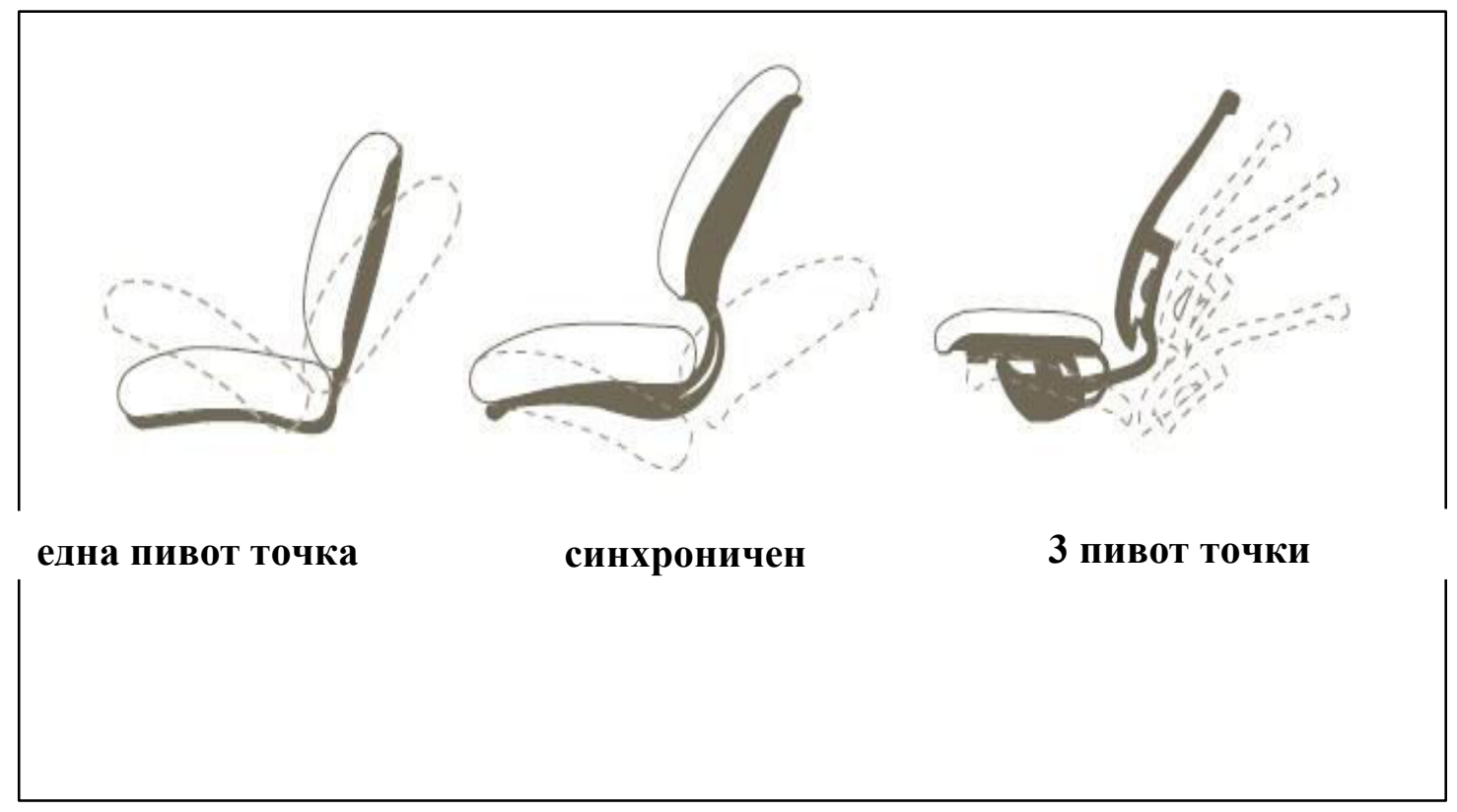

Слика.14Механизми за навалување на делот за потпирање

\section{Агол на седиштето (в)}

Закосувањето на седиштето обично се препорачува да е околу $7^{\circ}$ за столчиња што го исправуваат грбот $5^{8}$ и околу $25^{\circ}$ за столчиња за одмарање. 59

За да се ослободат мускулите седиштето треба да му дозволи на лицето што седи да ја промени положбата во текот на седењето.

Тоа е едно од барањата со кое повеќето итражувачи се согласуваат уште откако Акерблом пишуваше за тоа. ${ }^{60}$ Седиштата и заобленоста на потпирачот за грбот како и мекоста на површината за седење влијаат на слободата на лицето што седи да ја менува неговата положба.

Потпирачот за рацете исто така претставува важен дел од столот. Рацете претставуваат отприлика 10.2\% од вкупната тежина на телото, што може да резултира во значаен напор врз мускулите кои што се наоѓаат во горниот дел од грбот, рамениците и вратот. ${ }^{61}$

Статичниот напор (напор кој што се појавува при одложено стоење во непроменлива положба) драматично го зголемува ризикот од замор на мускулите и обично се прифатени како почеток на повредите. Овозможување на потпирач за рацете го намалува стресот врз 'рбетот, но од друга страна, со цел да биде ефикасен треба да биде

\footnotetext{
${ }^{57}$ The Ergonomic Seating Guide Handbook, Haworth, pp. 10

${ }^{58}$ E. Grandjean, et al. An Ergonomic Investigation of Multipurpose Chairs, Human Factors, v.15, n.3, 1973, pp. 247255

${ }^{59}$ E. Grandjean, et al., The Development of a Rest Chair Profile for Healthy and Notalgic People, Sitting Posture: Proceedings of the Symposium, Zurich, 1968, London: Taylor and Francis, 1969, pp. 193-201

${ }^{60}$ B. Akerblom, Standing and Sitting Posture, Stockholm: A B Nordiska Bokhandeln, 1948

${ }^{61}$ Pheasant, S. (1986). Bodyspace, Philadelphia: Taylor and Francis,129-134.
} 
соодветно дизајниран.

Со цел да се минимизира потенцијалот за контактен стрес, потпирачите за рацете треба да бидат користени со прекин при работата. ${ }^{62}$ Во Слика.15 прикажана е положбата на рацете која што треба да биде завземена.

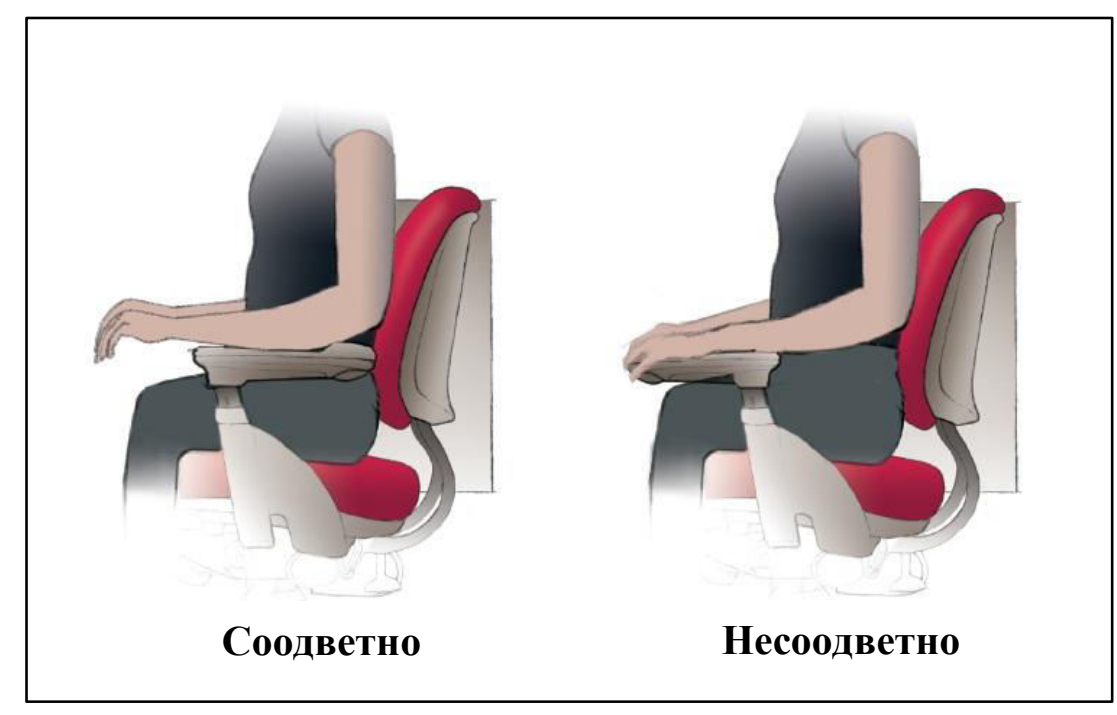

Слика.15 Положба на раце која што е соодветна

Потпирачите за раце кои што не можат да бидат подесувани и кои што предизвикуваат контактен стрес во слабите предели на лактот го може да го зголемат ризикот од повреди во овие делови. Со цел да се одговори соодветно на голем број на корисници, потпирачот за раце треба да има опција за подесување.

- Висина на потпирачот за раце- Употребата на потпирач за раце е многу ефективно при намалувањето на стресот на мускулите во горниот дел од грбот, вратот и рамениците.Поради тоа фундаментална потреба е истиот да може соодветно да се подесува. Има голема варијација во висината на потпирачот за раце. Стандардите во Северна Америка предложуваат минимална должина на подесување да биде 10.2 цм. На Цртеж.25 претставено е подесувањето на потпирачот на рацете.

\footnotetext{
${ }^{62}$ The Ergonomic Seating Guide Handbook, Haworth, pp. 7-8
} 


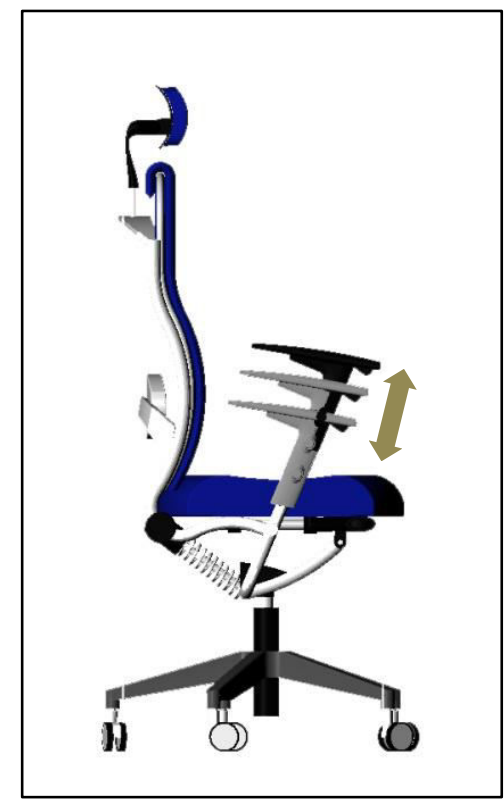

Цртеж.25 Потпирач за раце со висина која што е подесува

- Подесување напред-назад-Со цел да се приспособи на варијацијата на димензиите на луѓето, потребите на задачите и дизајнот на масата потребно е подесување на потпирачот напред или назад. Ова може да се достигне преку движење на потпирачот напред-назад. Потпирачите кои што не можат да бидат подесувани обично се судруваат во ивиците на масата. ${ }^{63}$ Изгледот на потпирачот кој што може се подесува напред-назад е прикажан на Цртеж.26.

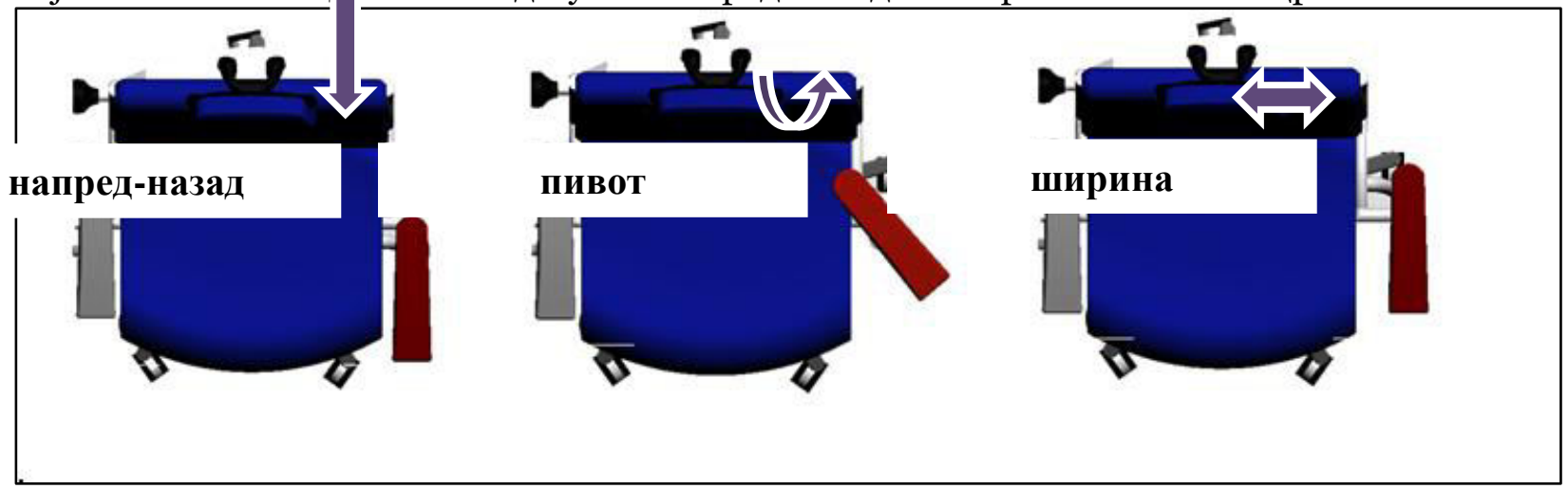

Цртеж.26 Различни подесувања на потпирач за раце

- Подесување во ширина и пивот- Со цел ефективно приспособување на варијацијата во ширината на различни корисници потребно е да се обезбеди подесување на потпирачот во ширина и пивот. Овие подесувања осигуруваат дека лицето кое што има поширока форма слободно може да го користи столот без проблем. Подесувањата во пивотот може да овозможи подесување согласно позицијата на задачата која што тековно ќе биде реализирана. Во некои случаеви

\footnotetext{
${ }^{63}$ The Ergonomic Seating Guide Handbook, Haworth, pp. 8
} 
ротација во целосно од 360 степени е потребна.23 Во Цртеж.22 претставени се подесувањата во ширина и пивот.

Подесувањата на елементите на столот не се еднакво пожелни од страна на секое лице. Според истражувањето спроведено во Стејт Фарм Иншјуранс (State Farm Insurance) дојдено е до заклучок дека можноста за подесување на мебелот е рангирана како треат најважен фактор додека леснотијата за подесување е рангирана како пет најважен фактор во работниот простор (многу поважно од интензитетот на светлина, приватност и контрола на бучава). 64 Подесувањето на висината на седиштето и висината на потпирачот за грб се рангирани повеќе од останатите подесувања. Подесувањето на висината на раката и аголот на седиштето не се рангирани како важни, Табела.2.

Табела.2 Рангирање на корисниците на важноста на карактеристиките за подесување
Карактеристики на столот
Просечна Рангирање

\begin{tabular}{lcc}
\hline Подесување на висина на седиште & 8.9 & 1 \\
\hline $\begin{array}{l}\text { Подесување на висина на потпирач на } \\
\text { грб }\end{array}$ & 8.2 & 2 \\
Можност за вртење при седење & 7.8 & 3 \\
\hline Наведнување на потпирач за грб & 6.6 & 4 \\
\hline Раце & 5.6 & 5 \\
\hline Подесување на агол на седиште & 5.2 & 6 \\
Можност за наведнување на назад & 5.2 & 6 \\
Тркалца & 4.8 & 8 \\
\hline Потпирач за нозе & 2.8 & 9 \\
\hline
\end{tabular}

Според истражувањето спроведено од страна на Климан и Пруниер (Kleeman и Prunier) најголеми подесувања се кај висината на седиштето, висината на потпирачт за грб и аголот на потпирачот за грб. Однизата карактеристики на седиштето подесувањето е рангирана како трета по важност (после комфорот и сигурноста), Табела.3. ${ }^{65}$

Табела.3 Рангирање на преферирани подесувања

\begin{tabular}{lll}
\hline Рангирање & Подесување & $\begin{array}{l}\text { Лица кои што се } \\
\text { согласуваат со ова } \\
\text { рангирање (\%) }\end{array}$ \\
\hline $\mathbf{1}$ & Висина на седиште & 73.3 \\
$\mathbf{2}$ & Висина на потпирач & 59 \\
$\mathbf{3}$ & Наведнување на потпирач & 64.4 \\
$\mathbf{4}$ & Длабочина на седиште & 63.8 \\
$\mathbf{4}$ & Слободен простор & 57.7 \\
$\mathbf{4}$ & Висина на потпирач за раце & 57.9 \\
$\mathbf{4}$ & Широчина на седиште & 50 \\
$\mathbf{5}$ & Широчина на потпирач & 56.7 \\
$\mathbf{5}$ & Странична поддршка на грбот & 51 \\
$\mathbf{6}$ & Потпирач на раце & 63.6 \\
\hline
\end{tabular}

\footnotetext{
${ }^{64}$ Springer, T.J., (1982), Visual Display Terminals: A comparative evaluation of alternatives. State Farm Mutual Automobile Insurance Company, Bloomington, Illinois, March

${ }^{65}$ Kleeman, W. And Prunier, T., (1980), Evaluation of chairs used by air traffic controllers of the US Federal Aviation Administration, in Easterby, R., Kroemer, K. H. And Chaffin, D. (eds) Nato Symposium on Anthropometry and Biomechanics: Theory and Application, London: Plenum Press
} 
Анализа на концептите на организација и опремување со мебел кај канцелариските простори магистерски труд Зејнелабедин Азири

\section{Примена на принципите на ергономија во канцеларискиот простор}

Во претходните делови на трудот претставени се карактеристиките на телото од аспект накомфорност и физилошка компатибилност и други карактеристики (т.е. циркулација,нерви и сл.) но и карактеристиките на столот кои што треба да ги поседува со цел да седостигне ергономско ниво на седење. Во овој дел од трудот претставен и прикажан е односот на човекот со ергономски дизајнираниот стол во канцеларискиот простор.

Идеалниот стол за работниот простор може лесно да биде подесена во позиција на седење. Висината на столот треба да биде подесена на тој начин што бутовите се во паралелен сооднос со подот и стапалата се рамни со подот или потпирачот за стапала. 66

Длабочината на столот (која што претставува должина од предниот дел на столот до задниот дел) треба да биде подесена на тој начин што личноста може да седи комфорно на потпирачот за грбот. Исто така, предниот дел на столот треба да биде заоблен на тој начин што нема да има притисок врз задниот дел на колената.Доколку столот има потпирач за раце, истиот треба да биде добро подесен. Тие не треба да бидат толку високи така што би ги подигнувале рамениците ниту да бидат толку широки така што би ги разместувале лактовите надвор од телото.

Потпирачот за грбот треба да се подесува и да дава поддршка на грбот. Потпирачот треба да се подесува и да нуди можност личноста да се наведнува околу 10 до 25 степени, што е слично на начинот на кој што личноста би седела додека се вози во кола.

Подесувањето на потпирачот за грб е од голема важност од аспект на промена на положбата на трупот што би се овозможило подобра циркулација како и опуштање на некои мускули кои што биле активни. Во Цртеж.27 претставени се точките кои што доаѓаат во контакт со телото во различни позиции на седење.

Столотисто така треба да биде стабилен. Подобро столот да има пет ногалки отколку четири ногалки. Исто така столот треба да биде повдижен.

На крај, перниците на столот треба да бидат покриени со издржлив и пропустлив материјал за тапацирање, и секогаш природен (во поголем процент) отколку синтетски. ${ }^{67}$

\footnotetext{
${ }^{66}$ U.S. Department of Energy, Office Ergonomics Employee Handbook, http://www-esh.Fnal.gov/CourseHandout_ Mat/Computer_Workstation_Ergonomics_FNoo0324/Office_Ergo_Handbook.pdf

${ }^{67}$ U.S. Department of Energy, Office Ergonomics Employee Handbook, http://www-esh.Fnal.gov/CourseHandout_ Mat/Computer_Workstation_Ergonomics_FNoo0324/Office_Ergo_Handbook.pdf
} 


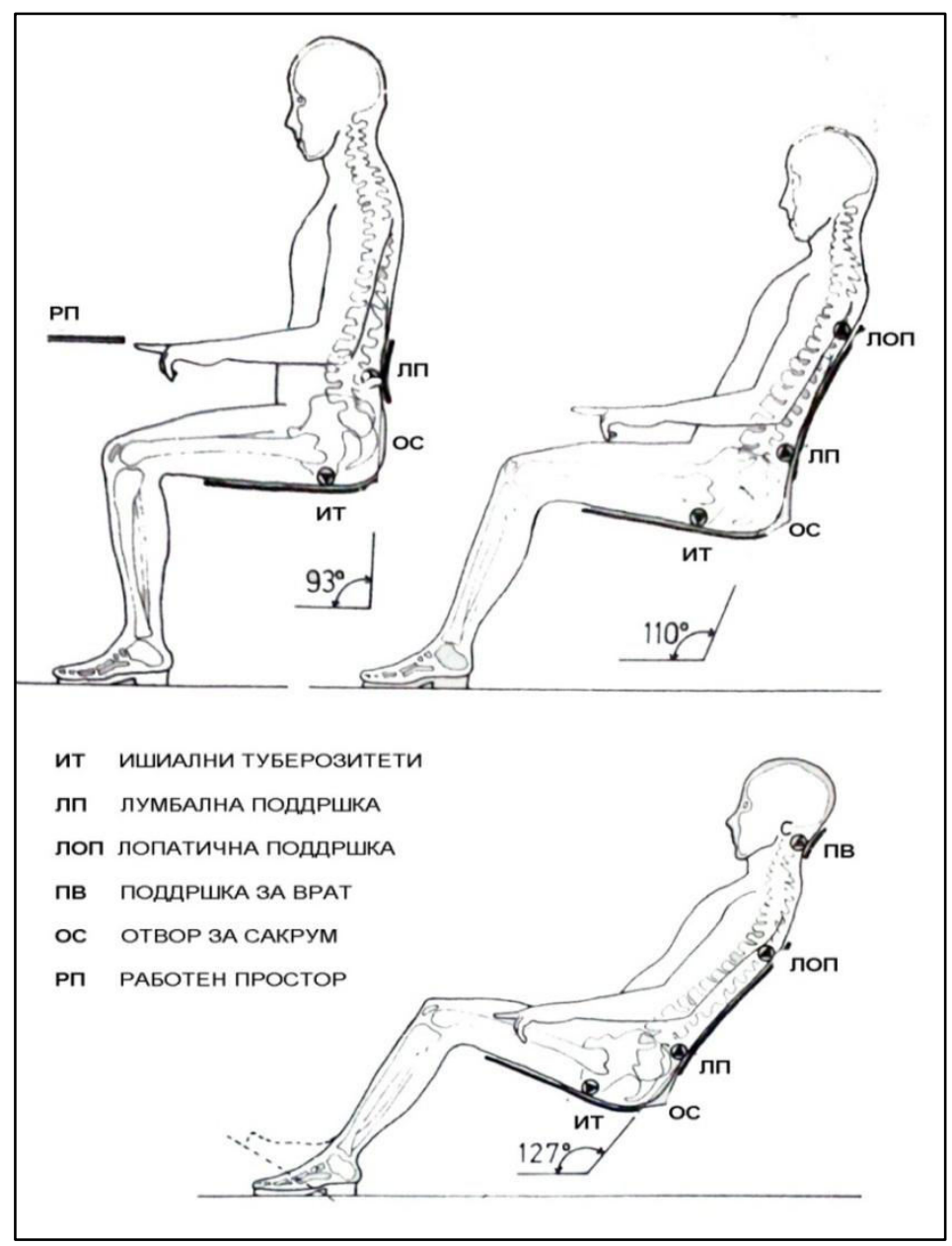

Цртеж.27Поддршка на телото во три различни положби

Доколку столот не може да биде подесен, истиотможе да биде подобрен на неколку начини, Цртеж.28:

- Додавање на перница или свиткана крпа на долниот дел од потпирачот на столот така што ќе се овозможи поддршка на лумбалниот дел од грбот;

- Потпирачите за грбот исто така достапни се во различни форми и големини кои што може да овозможат поддршка на грбот;

- Доколку стапалата не може да го достигнат подот, личноста може да користи потпирач за стапала кои што овозможуваат петиците да бидат подолу од прстите; 


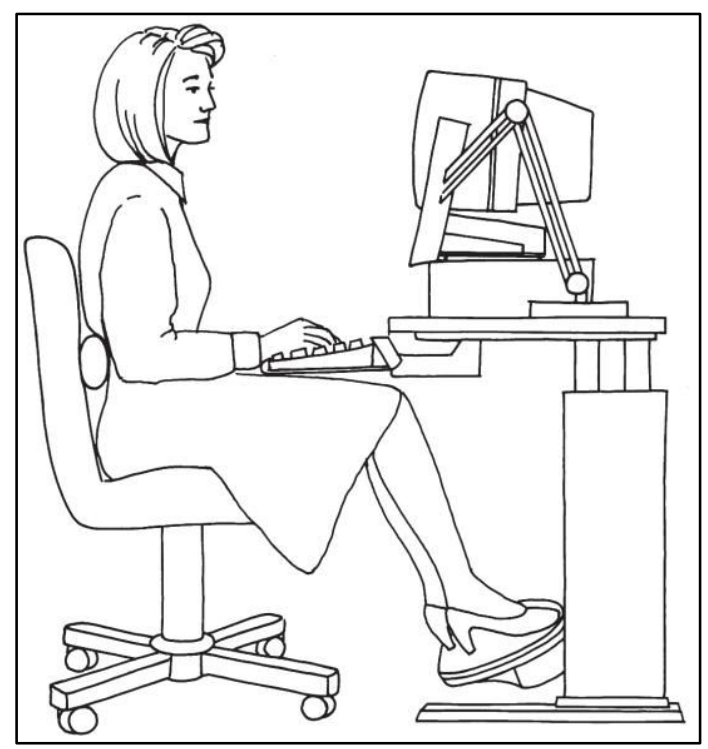

Цртеж.28 Подобрување на положбата на седење

Покрај тоа што сите предложени мерки се задоволени, сепак со цел да се постигне ергономско ниво столот треба да биде користен на соодветен начин. Подесувањата треба да бидат користени соодветно на димензиите на личноста. Исто така личноста треба да ја менува позицијата така што одредени мускули кои што биле активни еден период ќ бидат ослободени од тежина но исто така и ќе се подобри циркулацијата. ${ }^{68}$ Во Цртеж.29 претставени се главните карактеристики на столот.

\footnotetext{
${ }^{68}$ U.S. Department of Energy, Office Ergonomics Employee Handbook, http://www-esh.Fnal.gov/CourseHandout_ Mat/Computer_Workstation_Ergonomics_FNooo324/Office_Ergo_Handbook.pdf
} 


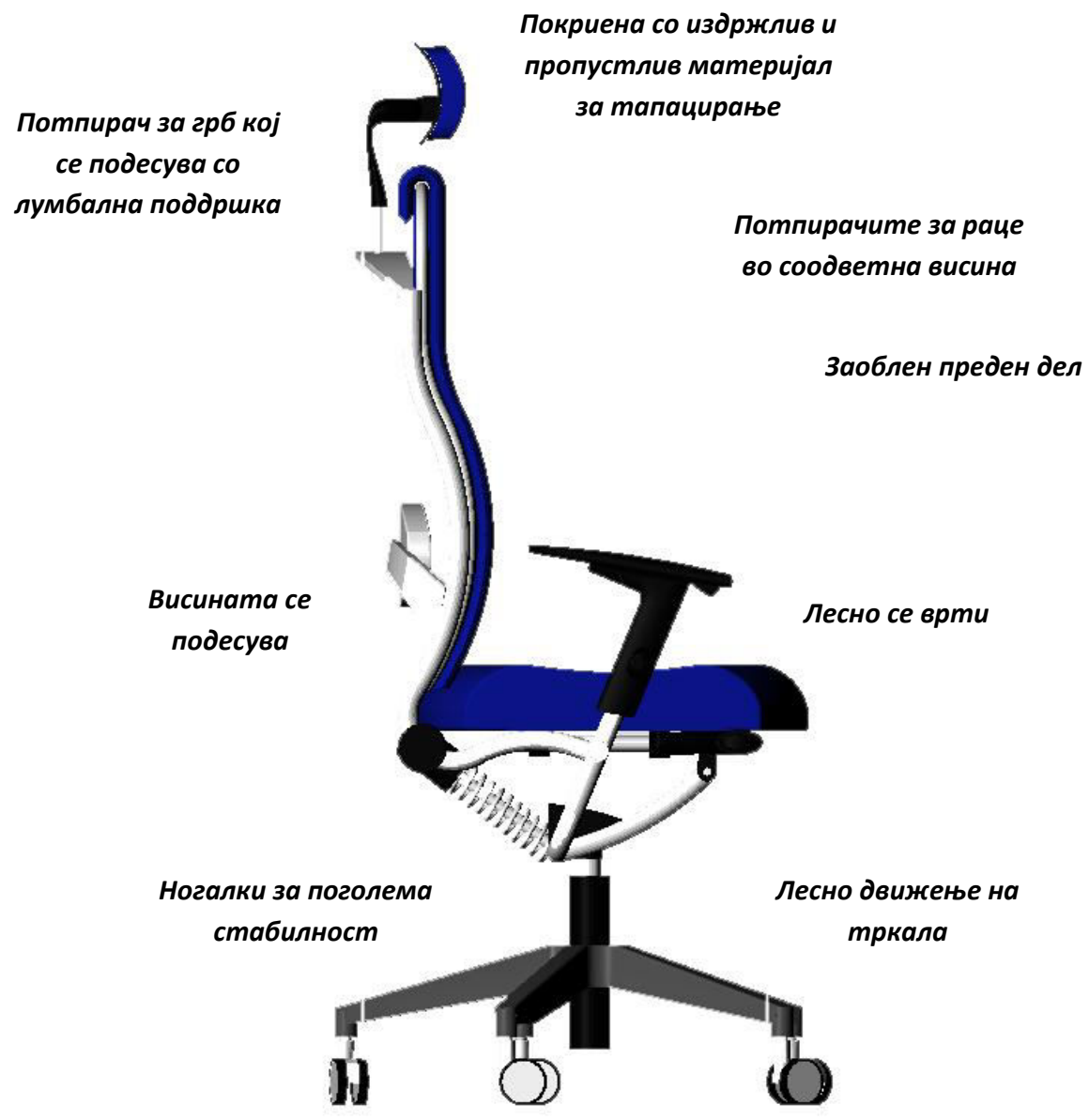

Цртеж.29 Главни карактеристики на столот во канцеларискиот простор 


\section{магистерски труд Зејнелабедин Азири}

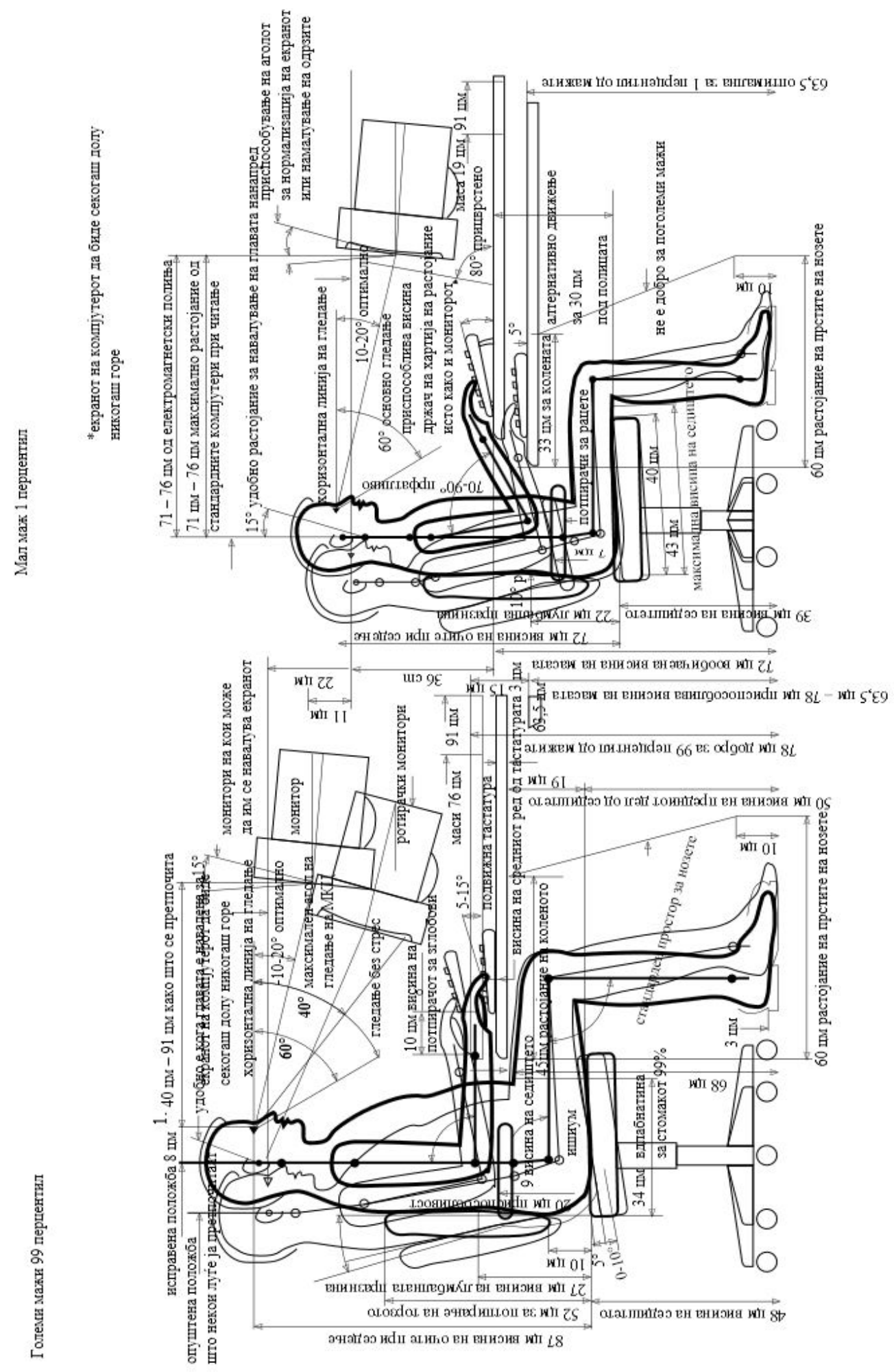

Цртеж 30: Шематски приказ на точните димензии на седење при работа на работна маса за мажи (покрупна и поситна градба на мажи) 69

\footnotetext{
${ }^{69}$ Nikoljski, Panevski E., Karanakov, V. „Impact of ergonomics on the design of the workspace”, I International Conference Wood technology and product design, Ohrid, 2013g., The International Scientific Technical Conference of Faculty of Design and Technologies of Furniture and Interior inSkopje, Republic of Macedonia
} 


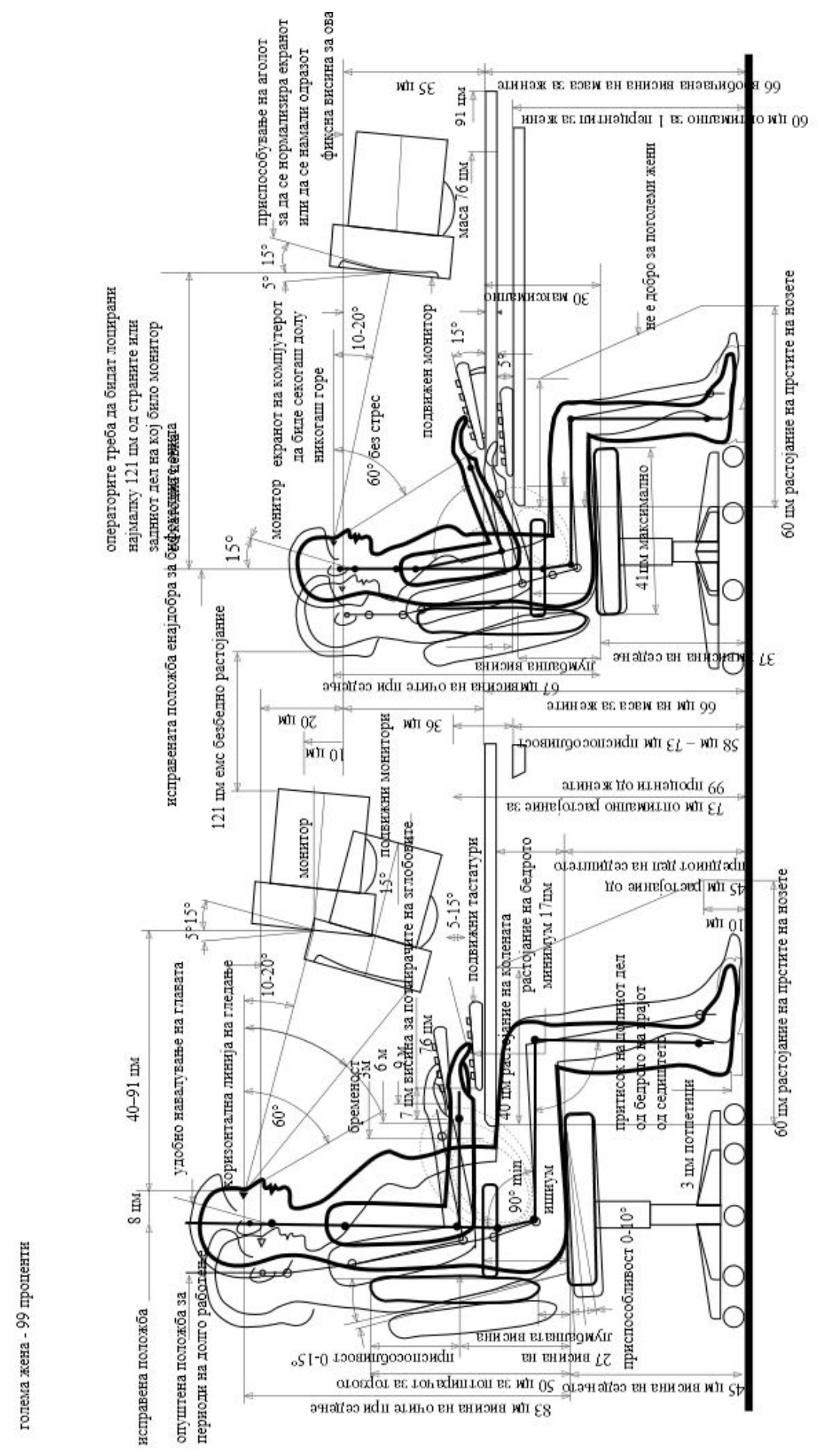

Цртеж 31: Шематски приказ на точните димензии на седење при работа на работна масаза жени (покрупна и поситна градба на жени) $)^{70}$

\footnotetext{
${ }^{70}$ Nikoljski, Panevski E., Karanakov, V. „Impact of ergonomics on the design of the workspace”, I International Conference Wood technology and product design, Ohrid, 2013g., The International Scientific Technical Conference of Faculty of Design and Technologies of Furniture and Interior inSkopje, Republic of Macedonia
} 

магистерски труд Зејнелабедин Азири

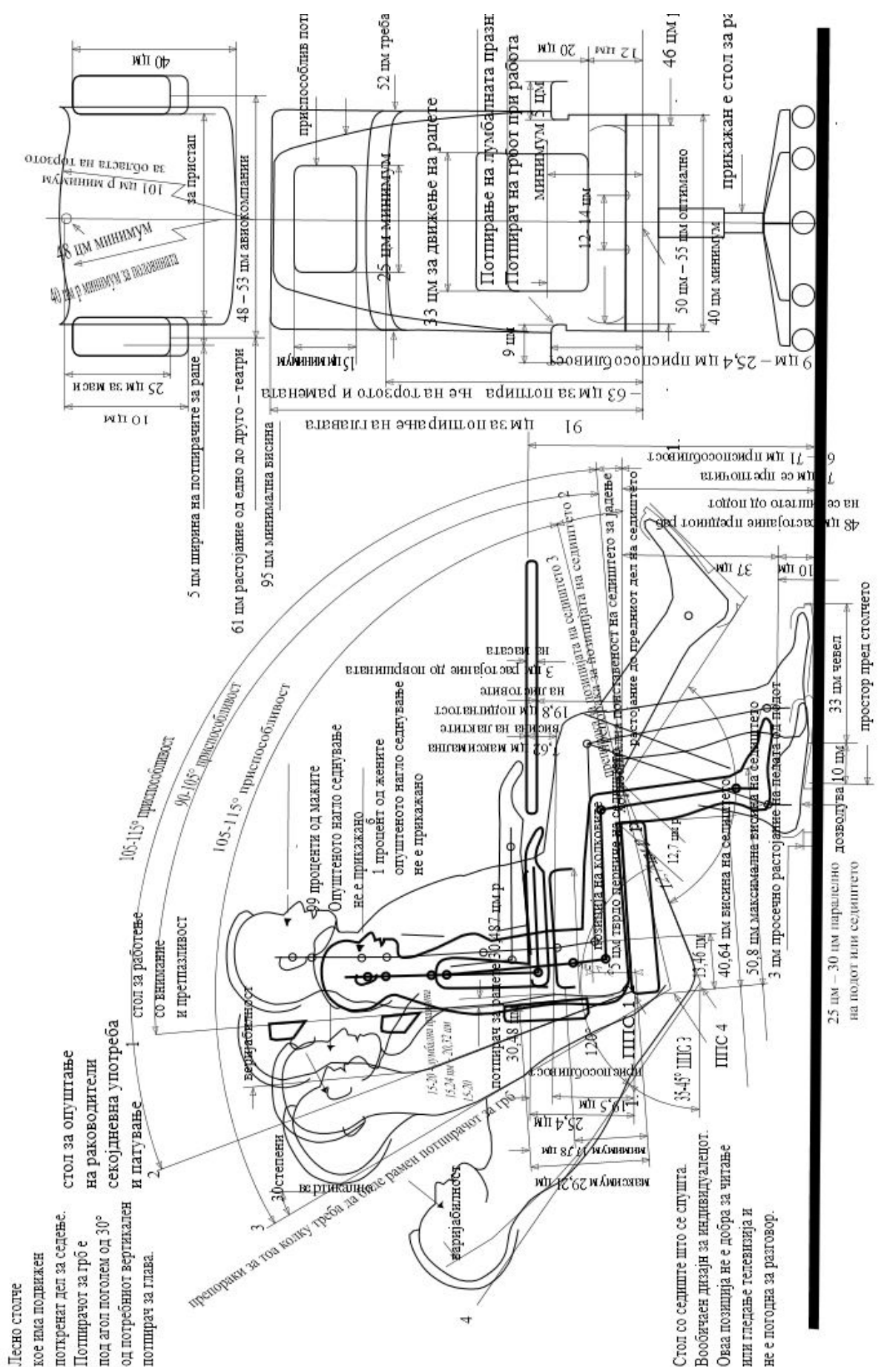

Цртеж 32: Стол и седење при работа на работна маса видови столови наменети за соодветно седење/работа71

${ }^{71}$ Nikoljski, Panevski E., Karanakov, V. „Impact of ergonomics on the design of the workspace”, I International Conference Wood technology and product design, Ohrid, 2013g., The International Scientific Technical Conference of Faculty of Design and Technologies of Furniture and Interior inSkopje, Republic of Macedonia 


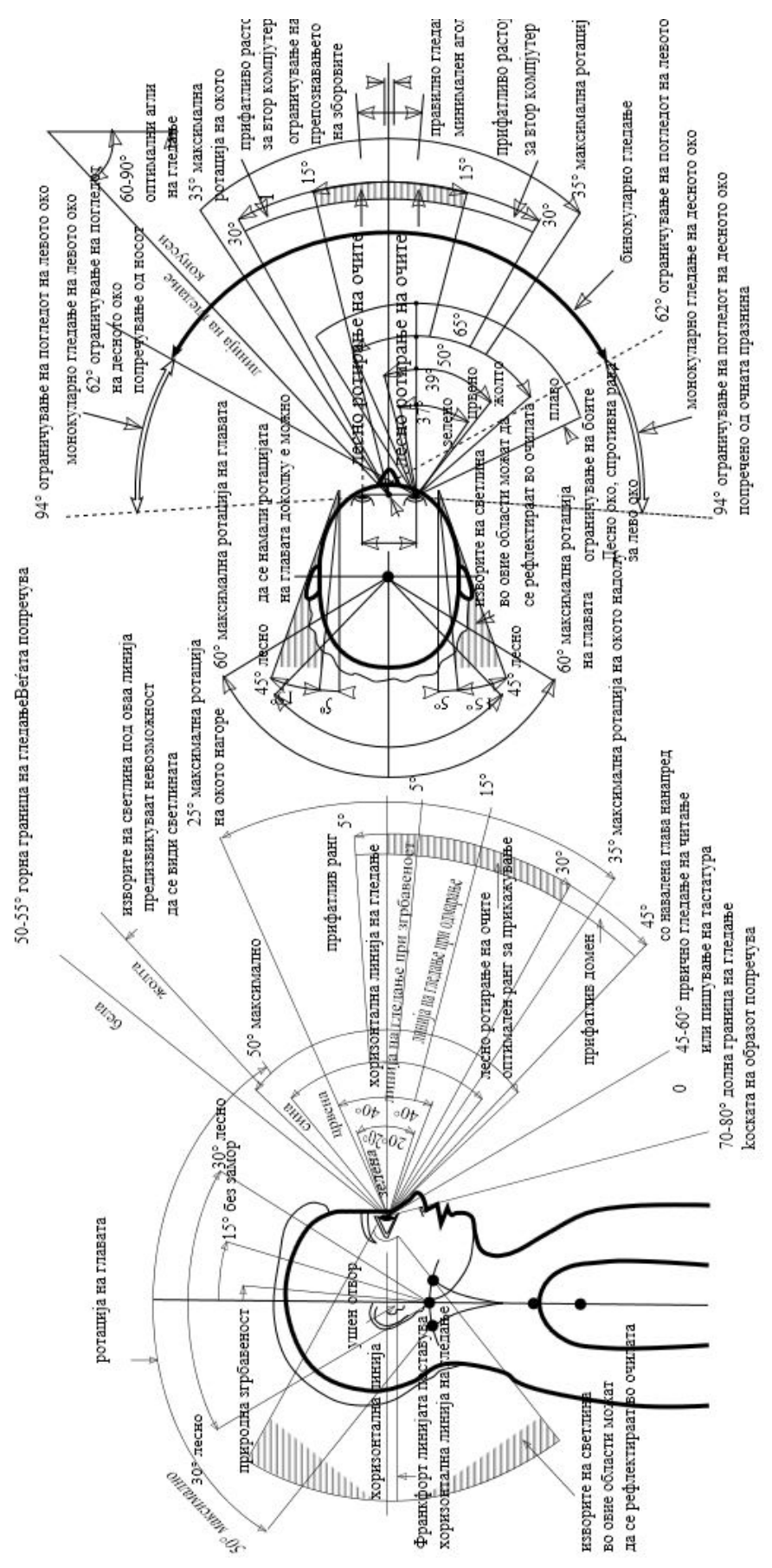

Цртеж 33: Видно поле при работа на работна маса72

\footnotetext{
${ }^{72}$ Nikoljski, Panevski E., Karanakov, V. „Impact of ergonomics on the design of the workspace”, I International Conference Wood technology and product design, Ohrid, 2013g., The International Scientific Technical Conference of Faculty of Design and Technologies of Furniture and Interior inSkopje, Republic of Macedonia
} 


\section{Комерцијални ергономски столици}

Во следниот дел од трудот претставени се неколку модели на ергономски дизајнирани комерцијални столици.

Во пракса едни од најпознати модели на ергономски столици претставуваат Херман Милер Ембоди (Herman Miller Embody Chair), Херман Милер Мирра 2 (Herman Miller Mirra 2 Chair),Херман Милер Аерон (Herman Miller Aeron), Гајгер Фореј Егзекјутиф Ситинг (Geiger Foray Executive Seating), Ситонит Фокус Таск (Sitonit Focus Task Chair) иСтилкејс Гесчур (Steelcase Gesture Chair).73

Херман Милер Ембоди(Herman Miller Embody Chair) столот, Слика.18 и Слика.19, е дизајнирана особено за луѓе кои работат подолг временски период на компјутери.

Херман Милер Ембоди (Herman Miller Embody Chair) столот овозможува поголемо движење што резултира со поголема циркулација и проток на кислород. Овој стол претставува прв кај кој што има позитивен придонес кон здравјето. Неговиот дизајн го намалува крвниот притисок и стресот. ${ }^{74}$ Технологијата на наведнување во Ембоди столот, Слика.16, се карактеризира на тој начин што точките на ротација се сместени во самото седиште и во потпирачот за грбот.

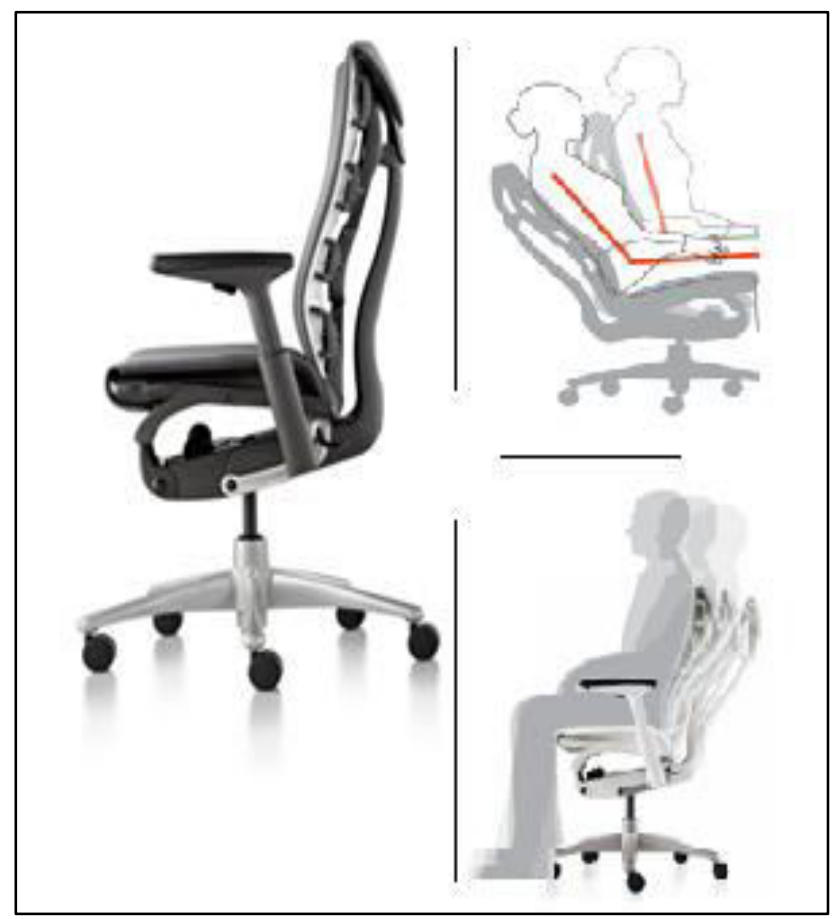

Слика.16Херман Милер Ембоди стол

\footnotetext{
${ }^{73}$ http://inthralld.com/2013/10/the-15-best-ergonomic-task-chairs-for-your-office/

${ }^{74}$ http://www.hermanmiller.com/products/seating/performance-work-chairs/embody-chairs.htm
} 


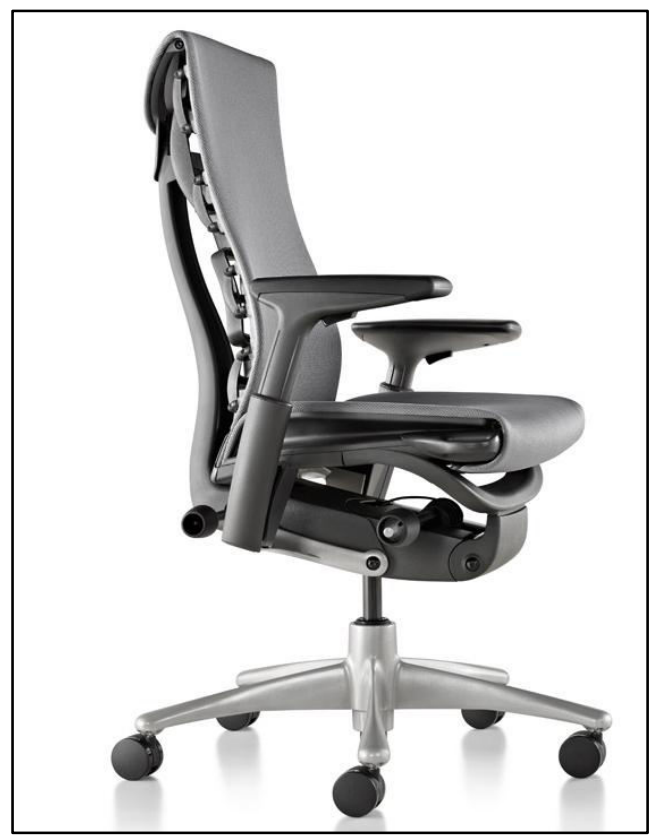

Слика.17Херман Милер Ембоди стол

На овој начин, потпирачот за грбот останува фиксен во однос на седиштето. Оваа технологија овозможува три зони на поддршка-за бутовите, коските во сакрумот и тораксот. Пелвисот останува стабилен без да има можност да се ротира.

Ембоди столот, овозможува да се постигне најздравата положба за оние лица кои штоработат на компјутер на таков начин каде што е намален притисокот на 'рбетот и дуринамален е протокот на течност од дискот.

Можноста за подесување на потпирачот за грбот придонесува за позиционирање на потпирачот во линија со природната крива на 'рбетот така што се постигнува и оддржува неутрална, балансирана положба, Слика.18.

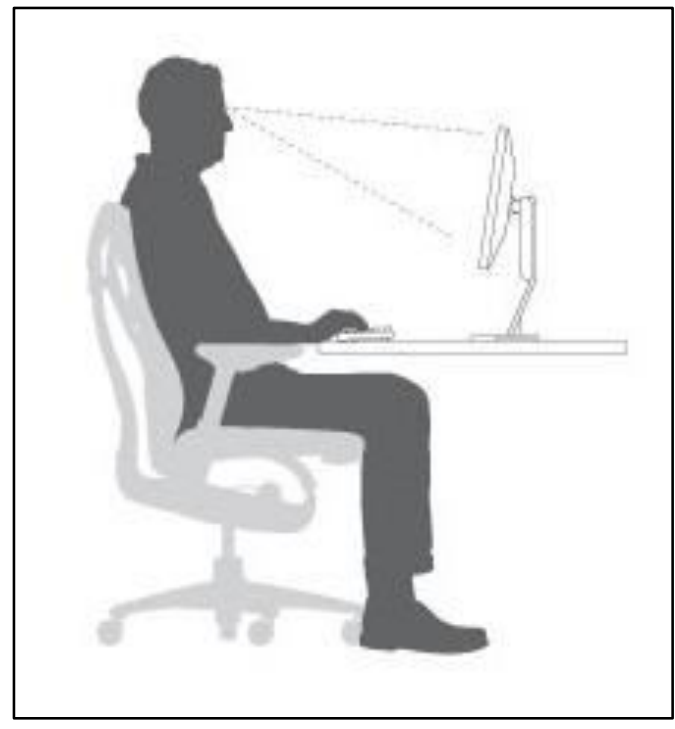

Слика.18Херман Милер Ембоди стол 
Пикселизираниотпотпирач создава површина на седиштето и потпирачот која што автоматски со конформира со секое движење на лицето кое што седи и исто така ја распределува тежината еднакво. Со вклопувањето на формата на лицето и со намалувањето на притисокот при седење, Ембоди столот ја зголемува циркулацијата на крвта, која што резултира со подобрување на протокот на кислород и намалување на чукањето на срцето.75Херман Милер Аерон (Herman Miller Aeron) столот е претставен во Слика.19.

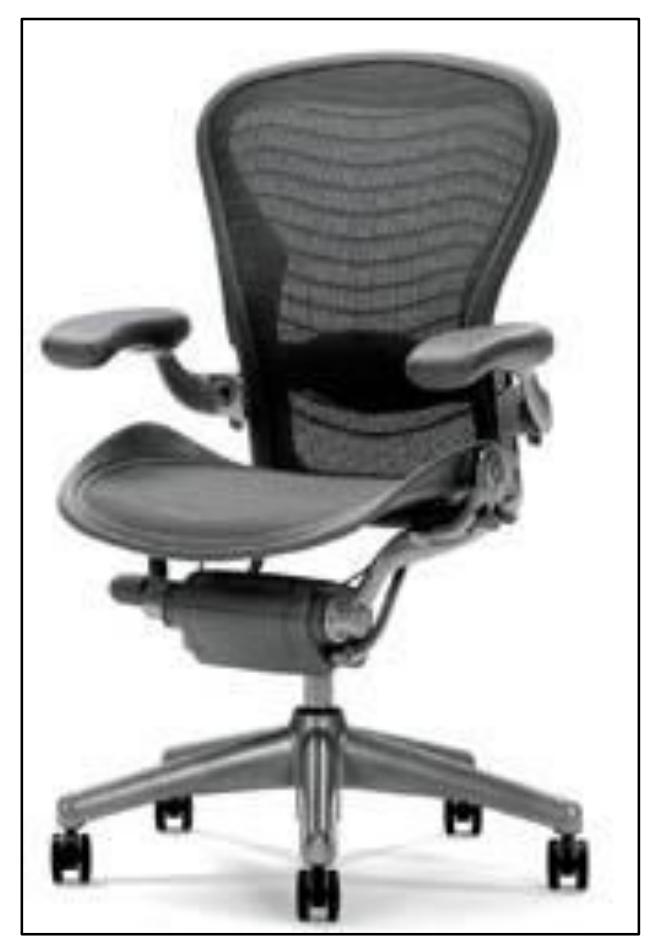

Слика.19Херман Милер Аерон стол ${ }^{28}$

Аерон има додаток, таканаречен PostureFit, кој што придонесува за оддржување на комфорноста и покрај тоа што се седи на неа долг временски период.Овој додаток дава поддршка на пелвисот и 'рбетот стои во природна линија избегнувајќи ја болката во грбот, Слика.20.76

\footnotetext{
${ }^{75}$ http://www.hermanmiller.com/products/seating/performance-work-chairs/embody-chairs.htm

${ }^{76}$ http://www.hermanmiller.com/products/seating/performance-work-chairs/aeron-chairs.html
} 


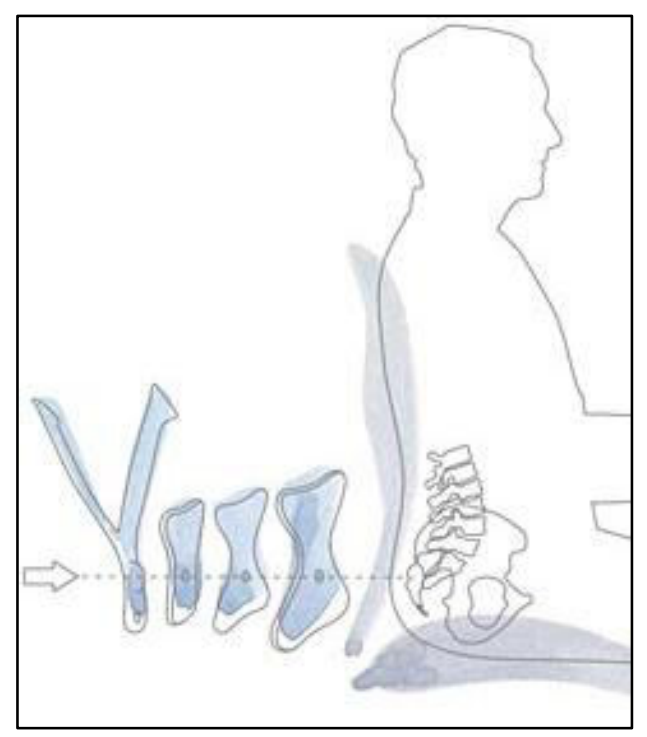

Слика.2оХерман Милер Аерон стол ${ }^{28}$

Потпирачот за грб е добро оформен и истиот е висок и широк. На овој начин се овозможува дасе намали притисокот во долниот дел на 'рбетот. Аголот на потпирачите зараце малку е зголемен накај задниот дел што го прави најприроден и најкомфорен. Крајот на предниот дел е заоблен што резултира со намалување на притисокот врз бутовите и подобра циркулација на крвта.Механизмот за навалување, Kinemat, овозможува вратот, рамениците, колковите, колената и глуждовите да се вртат на природен начин.За Аерон столот (делот за седење и потпирање) има посебно развиен материјал, Pellicle, Слика21. Со помош на овој материјал притисокот се оддржува на еднакво ниво низ целото тело и истовремено го оддржува трупот на пониска температура.77

\footnotetext{
${ }^{77}$ http://www.hermanmiller.com/products/seating/performance-work-chairs/aeron-chairs.html
} 

магистерски труд Зејнелабедин Азири

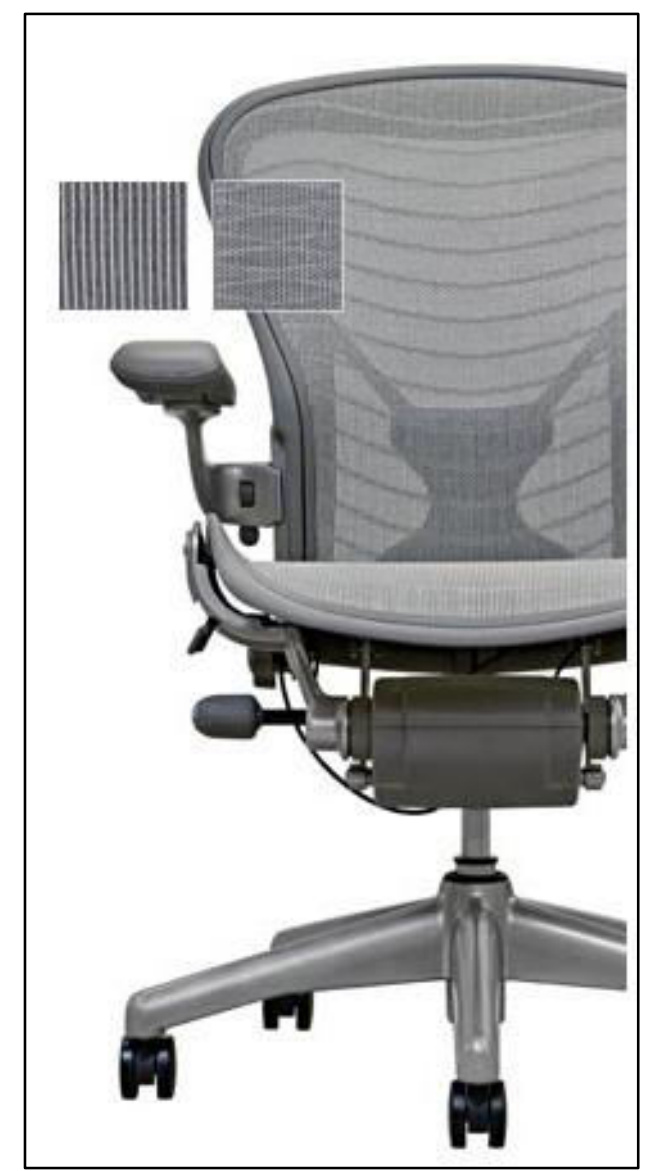

Слика.21Херман Милер Аерон стол

Херман Милер Мирра 2 (Herman Miller Mirra 2 Chair) столот е претставен во Слика.22. 


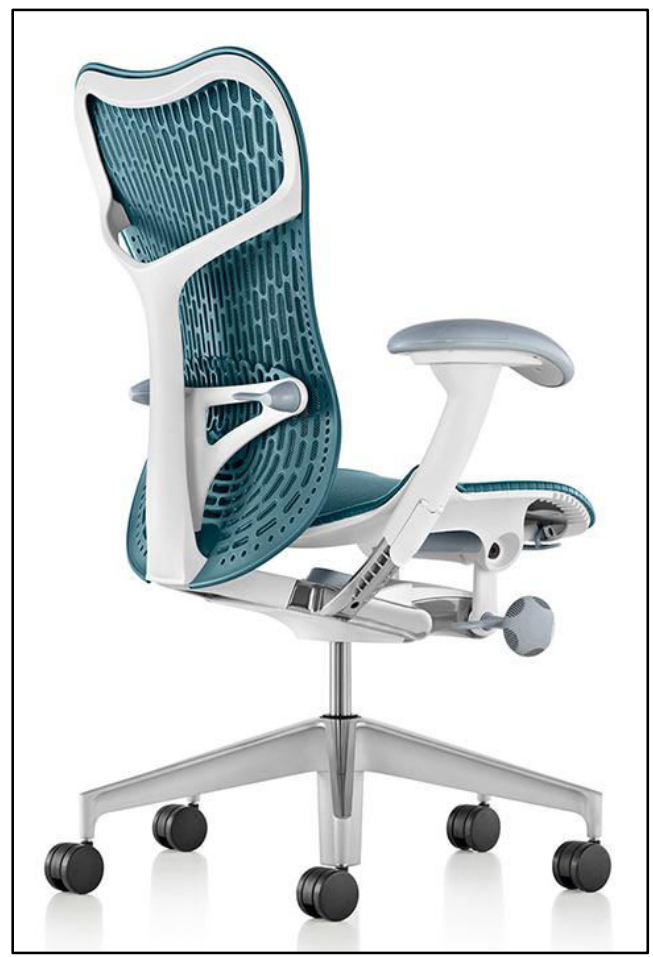

Слика.22Херман Милер Мирра 2стол

Кога лицето седи на столот, истата се адаптира на телото инстантно.Потпирачот за грб, Butterfly, е создаден од спој на ткаенина со полимер со цел да се обезбеди динамична поддршка која што го оддржува телото во здраваположба.

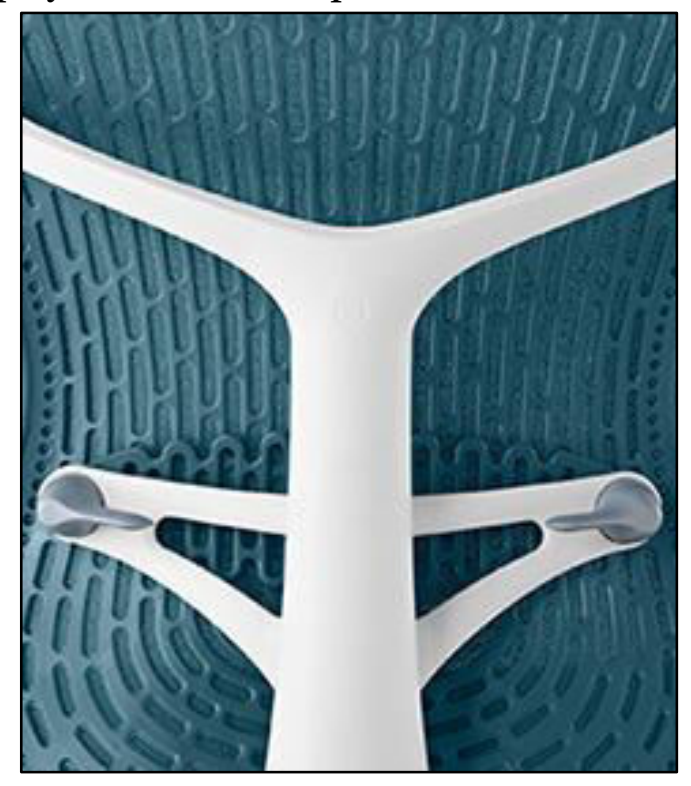

Слика.23Херман Милер Мирра 2стол

Во овој стол има и поддршка за сакрумот, PostureFit, која што овозможува 'рбетот да биде природно поставен. На овој начин се избегнува болката во грбот и вратот. 


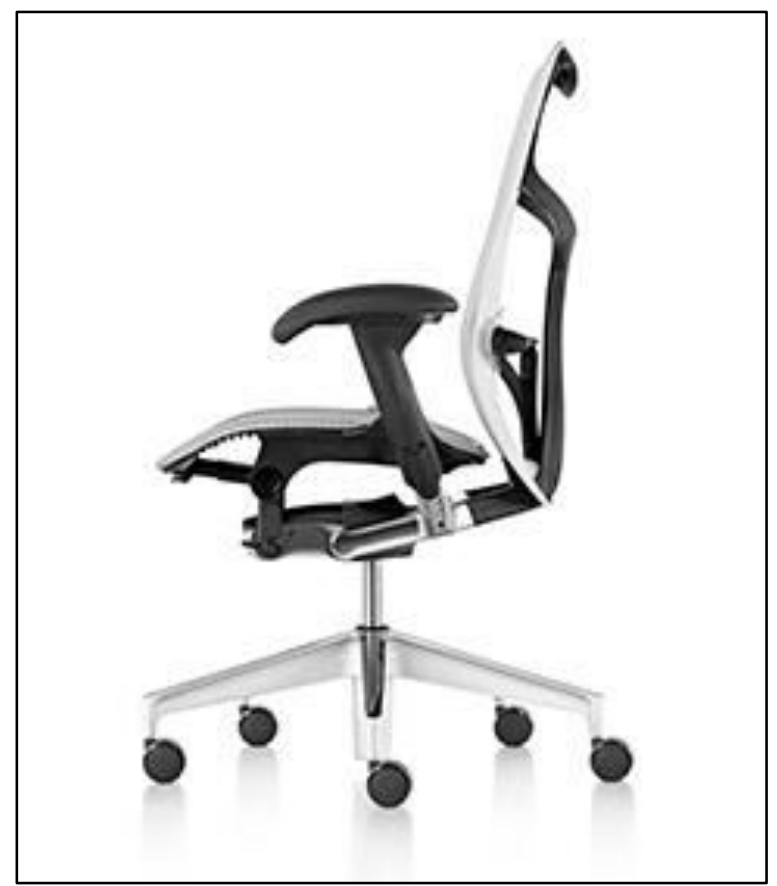

Слика.24Херман Милер Мирра гстол

Материјалот од кој што е направено седиштето овозможува распределба на притисокот на еднаков начин и овозможува воздухот на струи лесно така што се избегнува зголемување на топлината и го чува телото во пониска температура. ${ }^{8}$

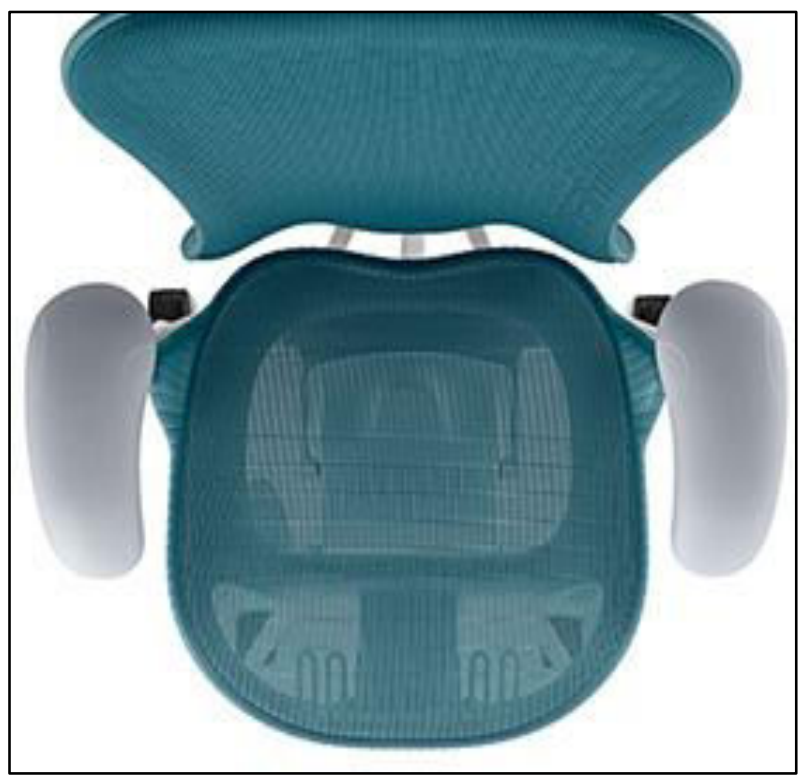

Слика.25 Херман Милер Мирра 2стол

Столот Гајгер Фореј Егзекјутиф Ситинг (Geiger Foray Executive Seating) е претставена во Слика.26.

\footnotetext{
${ }^{78} \mathrm{http}: / /$ www.hermanmiller.com/products/seating/performance-work-chairs/mirra-2-chairs.html
} 


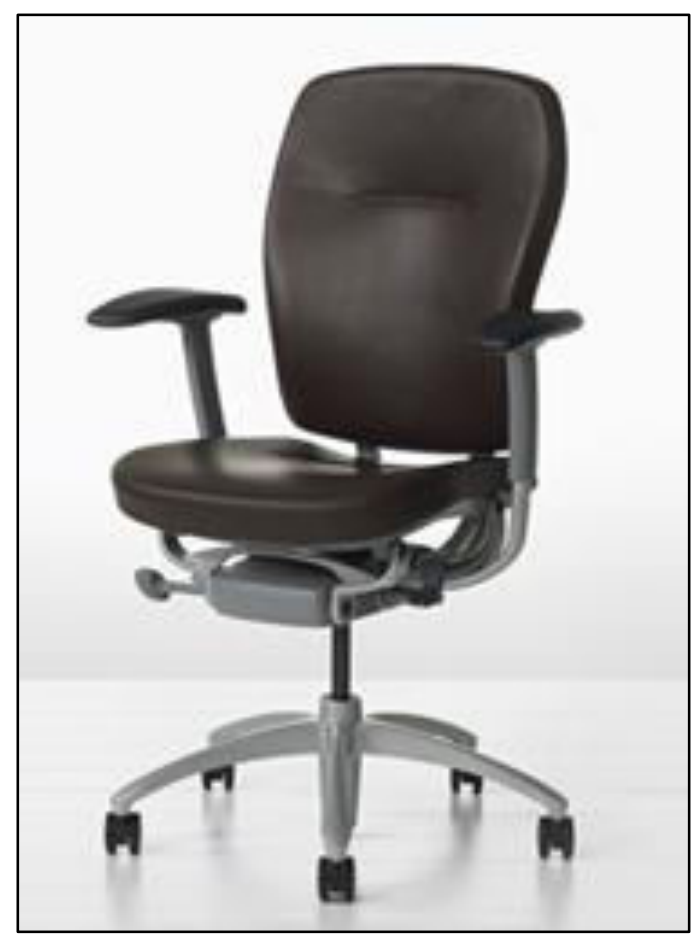

Слика.26Стол Гајгер Фореј Егзекјутиф Ситинг

Столот Гајгер Фореј Егзекјутиф преставува прв дизајн кој што ги комбинира комфорноста и луксузот кој што се бара од извршните директори со перформанс кој што е ориентиран кон извршување на задачата. 79

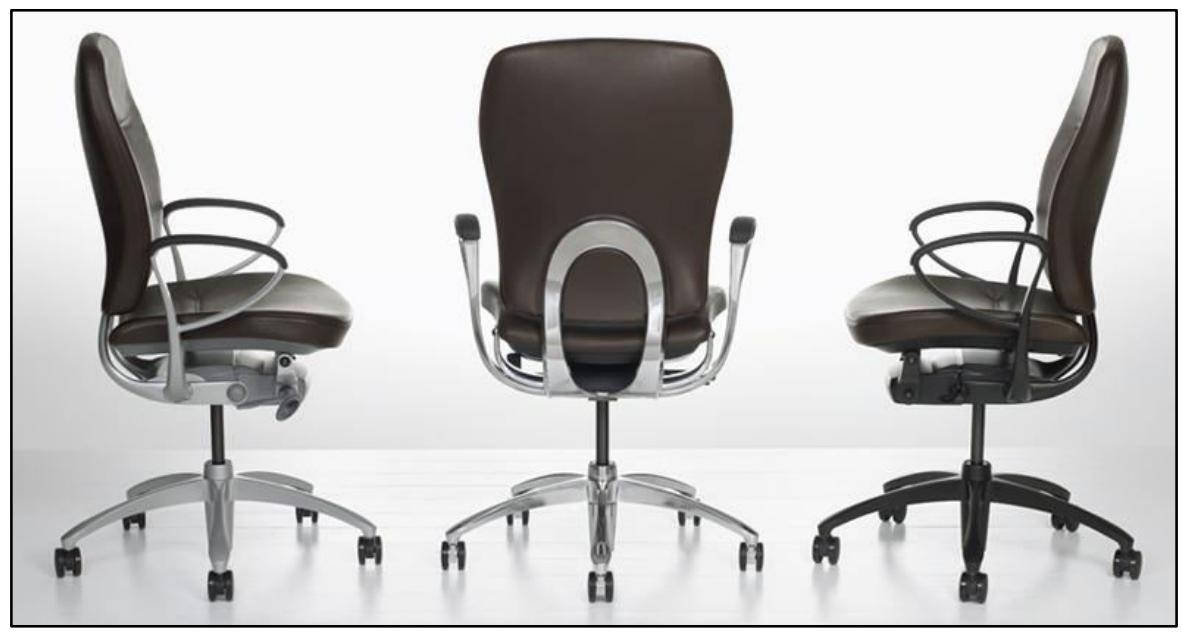

Слика.27Стол Гајгер Фореј Егзекјутиф Ситинг

Ситонит Фокус Таск (Sitonit Focus Task Chair) столот е претставен во Слика.28.

\footnotetext{
${ }^{79} \mathrm{http} / /$ www.geigerintl.com/products/seating/task-chairs/foray.html
} 


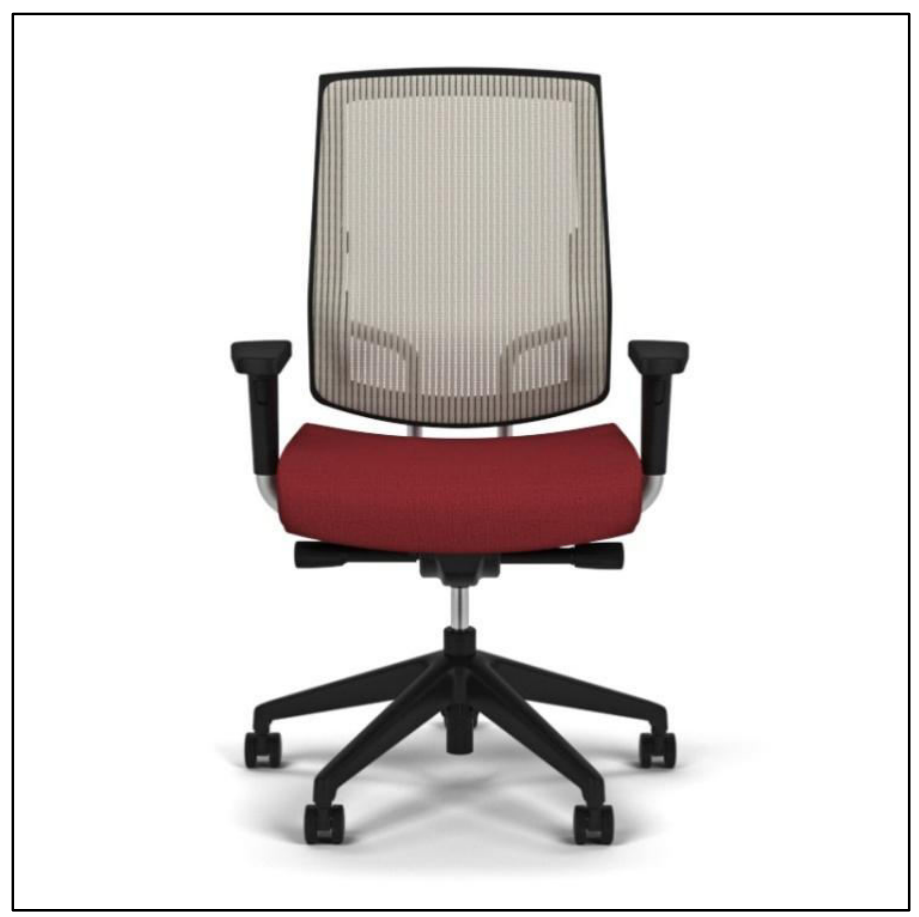

Слика.28Стол Ситонит Фокус Таск

Овој модел на стол е дизајниран за приватни канцеларии или простории каде што има поголема соработка. Потпирачот за грб е дизајниран во форма на буквата "Y“.80

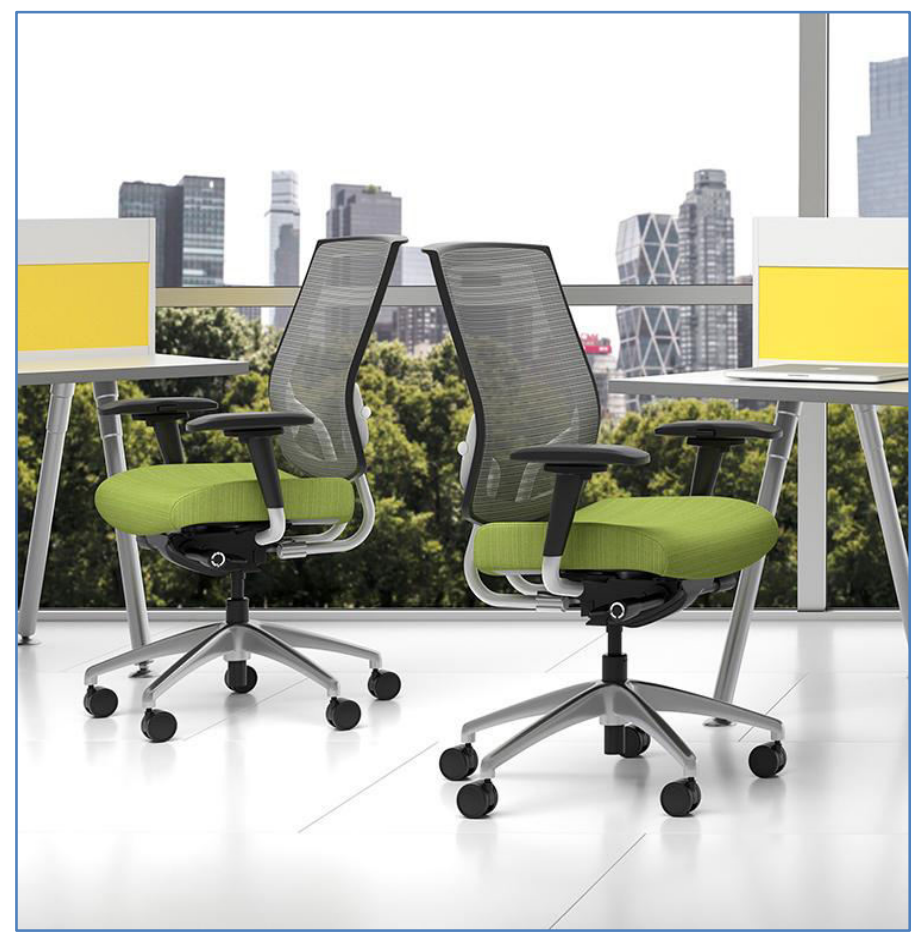

Слика.29Стол Ситонит Фокус Таск

${ }^{80}$ http://www.sitonit.net/productcatalog/focuswork_taskchair.html 
Стилкејс Гесчур (Steelcase Gesture Chair) столот е претставен во Слика.31.

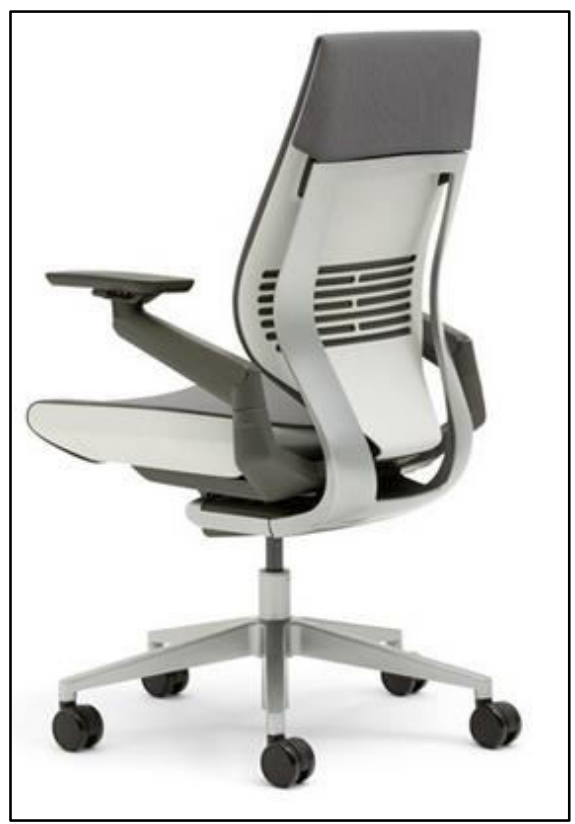

Слика.3о Стол Стилкејс Гесчур

Столот Стилкејс Гесчур претставува прв канцелариски стол дизајниран со цел да овозможи поддршка на интеракциите на човекот со денешната технологија. Инспирирана е од движењето на човековото тело и креирана во согласност на начинот на кој што работи денешниот човек. ${ }^{81}$

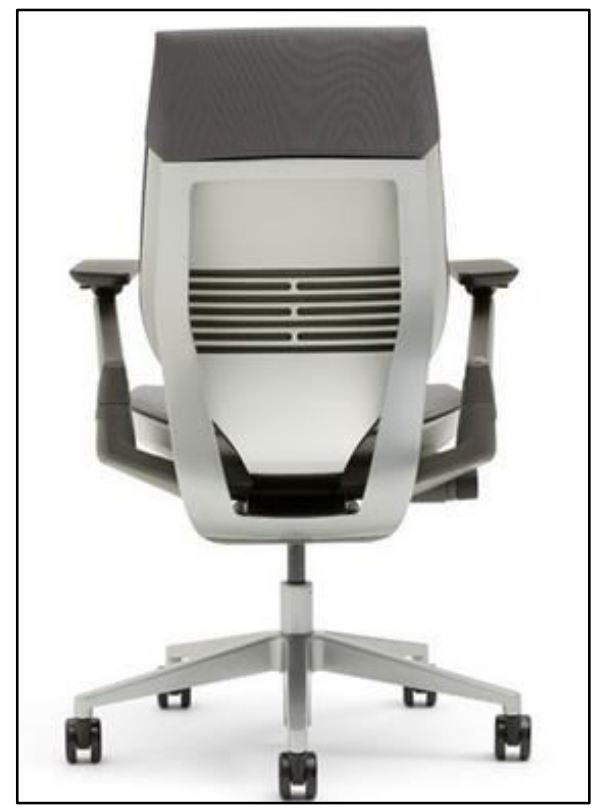

Слика.31 Стол Стилкејс Гесчур

${ }^{81} \mathrm{http}: / /$ www.steelcase.com/en/products/category/seating/task/gesture/pages/overview.aspx 


\section{5.Анализа на одделни примери на квалитетно опремен канцелариски простор од почетокот на 210т век до денес}

Како што беше наведено во воведот на овој труд, опремувањето на канцеларискиот простор има различен концепт во зависност од дејноста на компанијата.За цел на оваа точка во овој дел ќе се направи анализа на одделни примери на квалитетно опремен канцелариски простор.Периодот кој што е земен во предвид се последниве 14 години односно почетокот на 21 век до денес.Како предмет на анализа на примери од квалитетно опремени канцелариски простори, земени се канцелариските простори на следниве компании,

- Блу Комуникејшн (Blue Communication)

- Кунингам груп (The Cuningham Group)

- Викс (WIX Lithuania)

\section{1.Блу Комуникејшн}

Компанијата Блу Комуникејшн се наоѓа во Монтреал, Канада. Компанијата работи со развој на интернет страници, мобилни апликации, интернет продажба и останата дејност. ${ }^{82}$

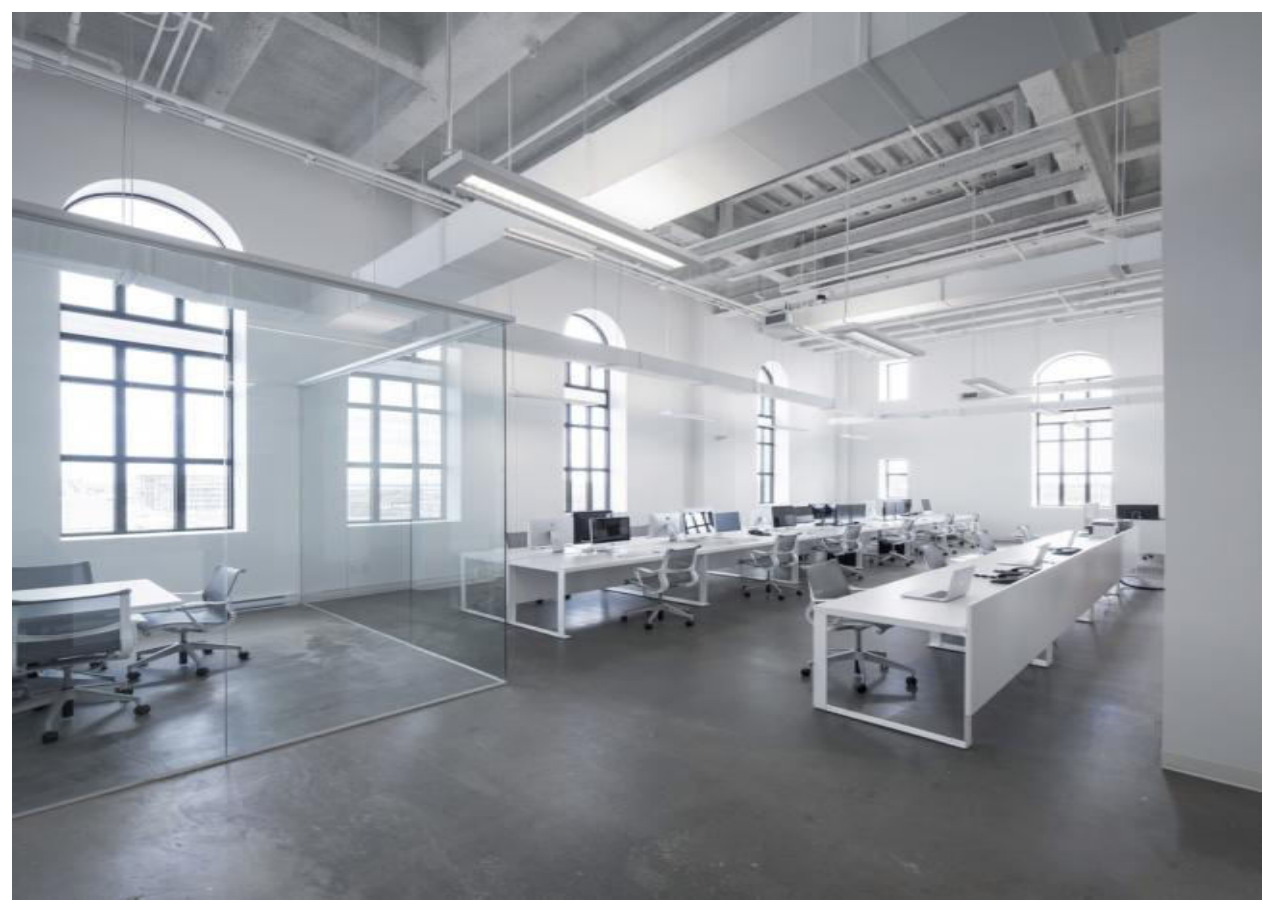

Слика.32 Просторот за вработени во канцеларискиот простор на компанијата Блу Комуникејшн Монтреал, Канада

\footnotetext{
${ }^{82}{ }_{7} \mathrm{http} / / /$ www.officedesigngallery.com/2014/09/07/blue-communications-agency-office/
} 
Канцеларискиот простор на компанијата е со големина од 256 м2 и истиот е лоциран на осмиот кат од објектот на иновативниот центар ИНГО.Како што може да се види на сликите подолу канцеларискиот простор кај оваа компанија е отворен. Само просторот за состанок е преграден со прозирен материјал.

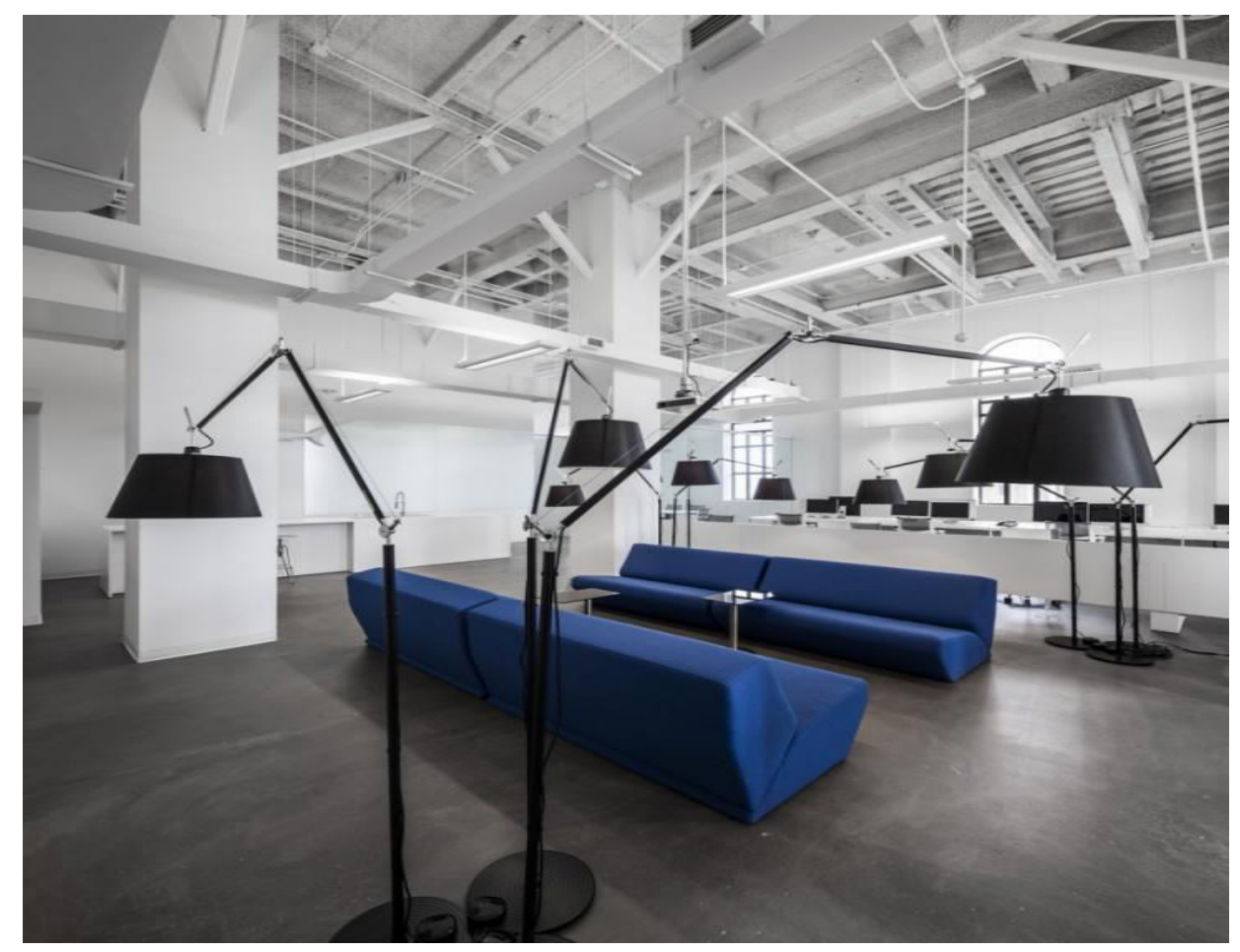

Слика.33 Простор за одмор во канцеларискиот простор на компанијата Блу Комникејшн Монтреал, Канада

Просторот за вработените, Слика.32, е опремен со маси, столици за секој вработен како и компјутери. Просторот за одмор, Слика.33, е опремен со долги фотељи за седење и мали додатоци за чување на одредени предемети. Просторот за јадење, Слика.34, е опремен со мијалник кој што е споен со висока маса покрај која се сместени две високи столици. Просторот за состанок е опремен со маса и столици. Отворениот тип, им овозможува на вработените полесна меѓусебна комуникација. 


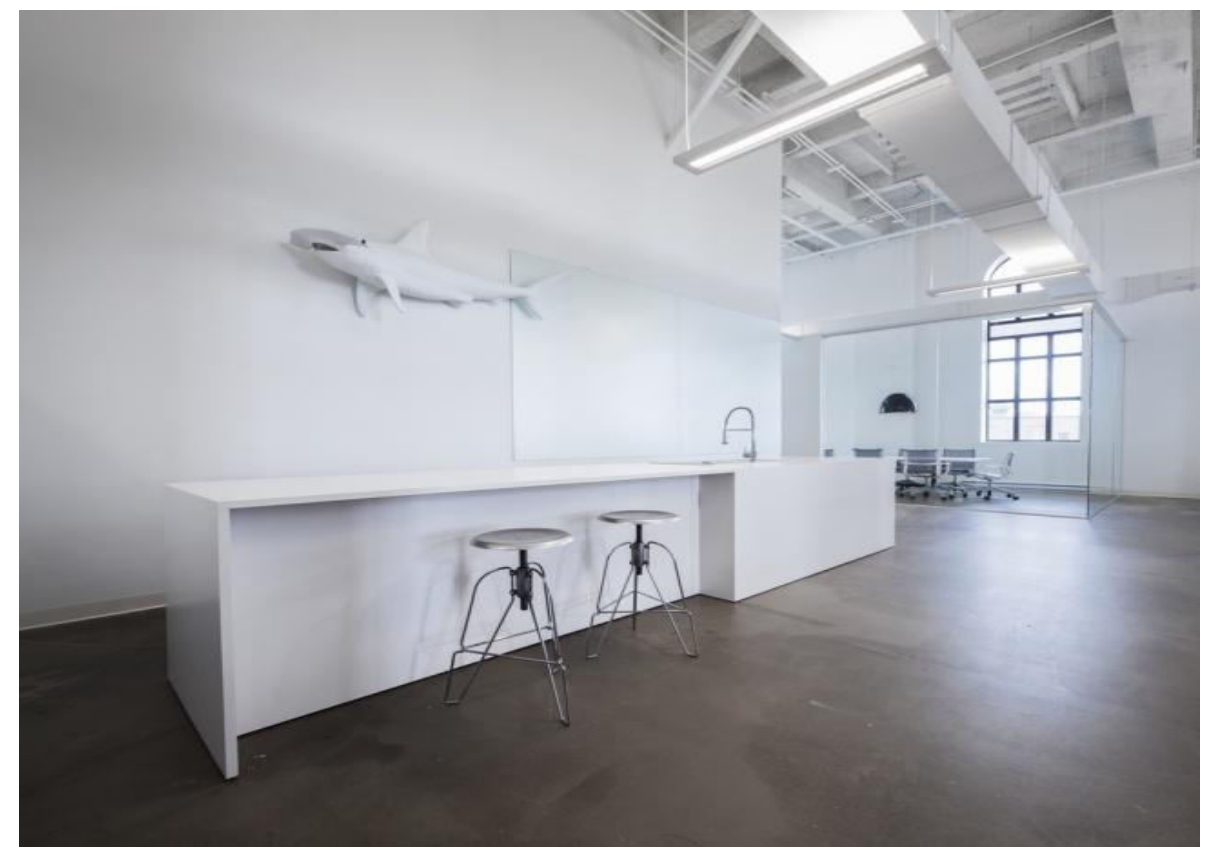

Слика 34. Простор за јадење во канцеларискиот простор во компанијата Блу Комуникејшн Монтреал, Канада

\section{2.Кунингам Груп}

Компанијата Кунингам Груп работи во повеќе градови во САД додека канцеларискиот простор кој што е тема на анализа во овој труд се наоѓa во градот Лос Анџелес. Компанијата работи со архитектура, внатрешен дизајн, планирање и градежништво. ${ }^{83}$

Канцеларискиот простор воглавно се состои од простор за вработените, простор за одмор и кујнски простор.

Просторот за вработени, Слика.35, воглавно е опремен со маси и столици и компјутери.

Просторот за одмор, Слика. 36, е опремен со кауч и столови и маса. Покрај тоа, покрај овој простор има внатрешна градина, која покрај тоа што го филтрира воздухот во канцеларијата туку и го поврзува просторот со природата.

\footnotetext{
${ }^{83}{ }^{\mathrm{http}}$ ///www.archdaily.com/335749/hayden-place-cuningham-group/
} 


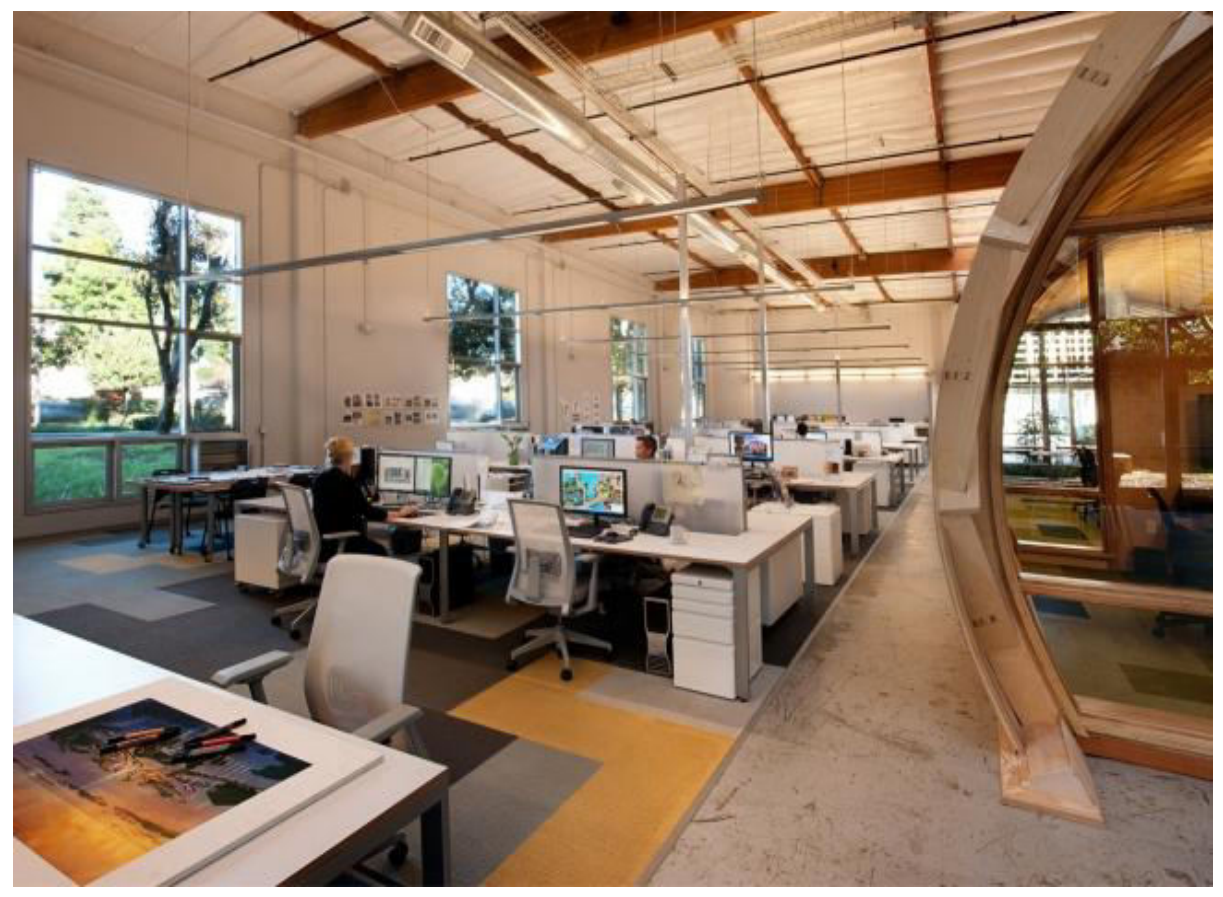

Слика.35 Простор за вработени во канцеларискиот простор на Кунингам Груп во Лос Анџелес, САД 8

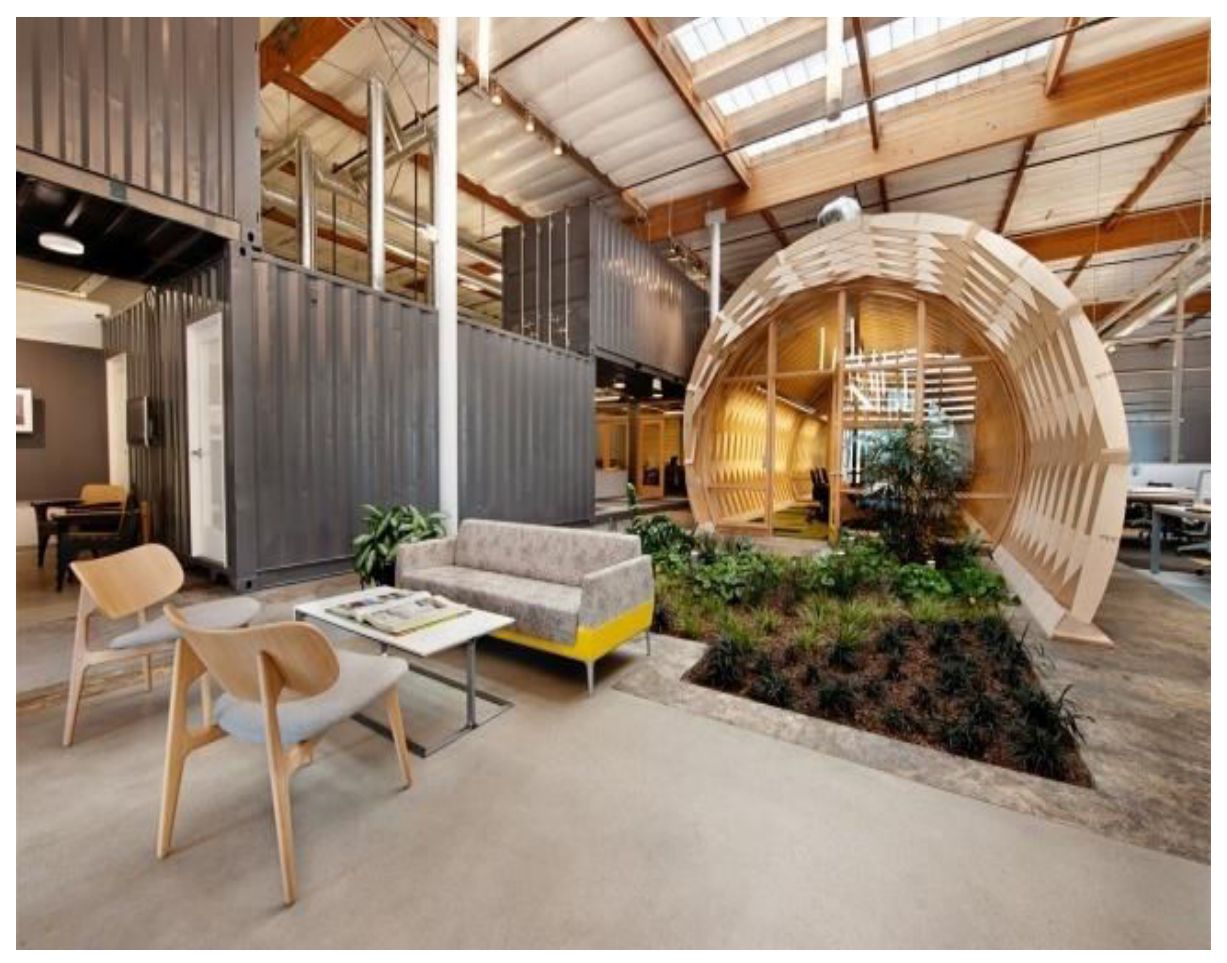

Слика.36 Простор за одмор во канцеларискиот простор на Кунингам Груп во Лос Анџелес, САД 8 
Анализа на концептите на организација и опремување со мебел кај канцелариските простори магистерски труд Зејнелабедин Азири

Другиот простор за одмор, Слика.37, е опремен со маса и столови.

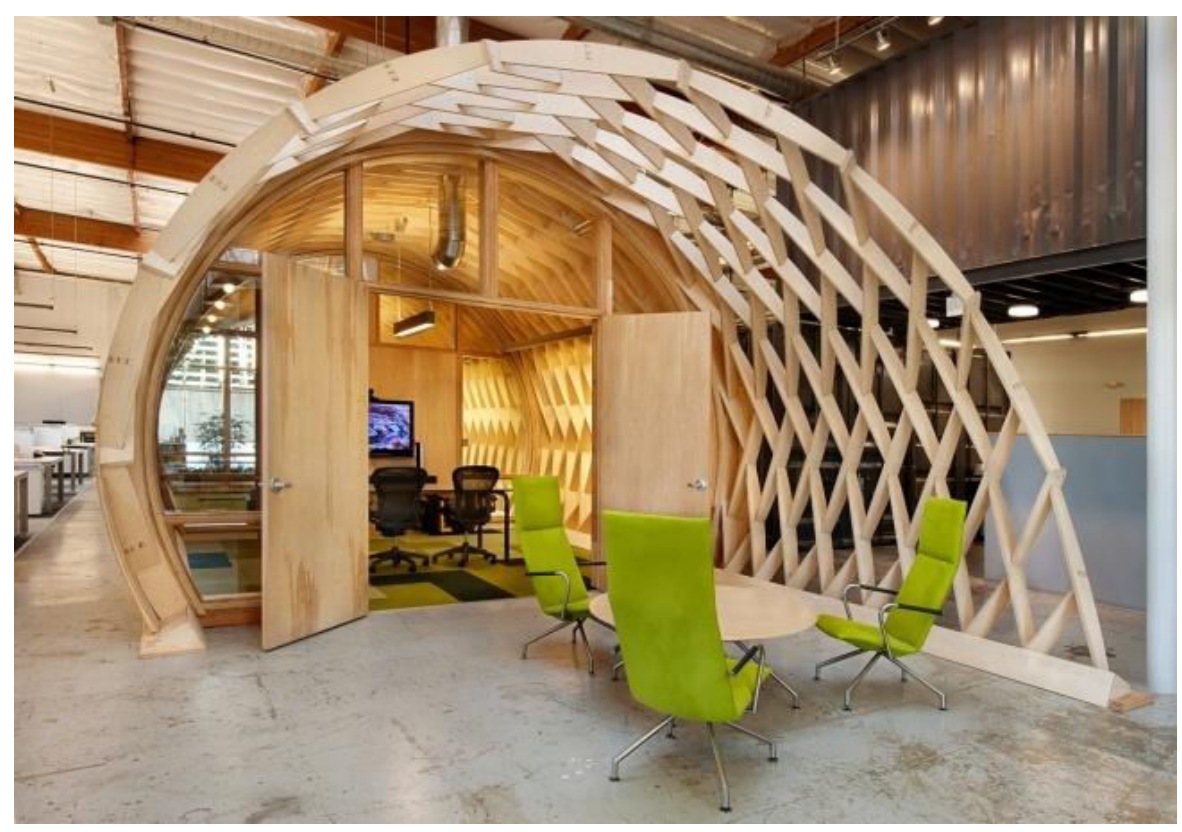

Слика.37 Простор за одмор во канцеларискиот простор на Кунингам Груп во Лос Анџелес, САД

Просторот за состанок, Слика.38, е преграден со дрвен материјал и завзема форма на тунел. Истиот простор е опремен со столици, маса и телевизор. 84

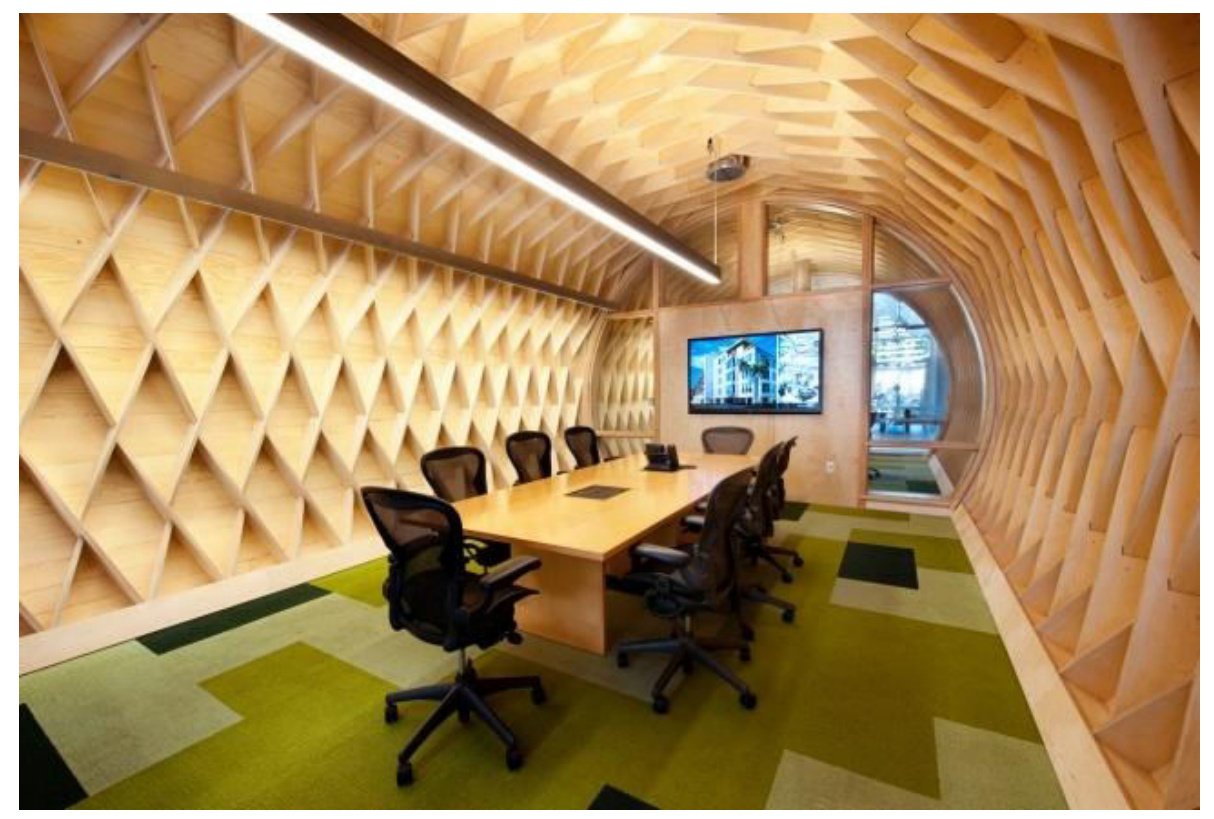

Слика.38 Простор за состанок во канцелариски простор на Кунингам Груп во Лос Анџелес, САД

\footnotetext{
${ }^{84}$ http://www.archdaily.com/335749/hayden-place-cuningham-group
} 
Кујнскиот простор, Слика.39, е опремен со апарати за домаќинство како и столици и маса.

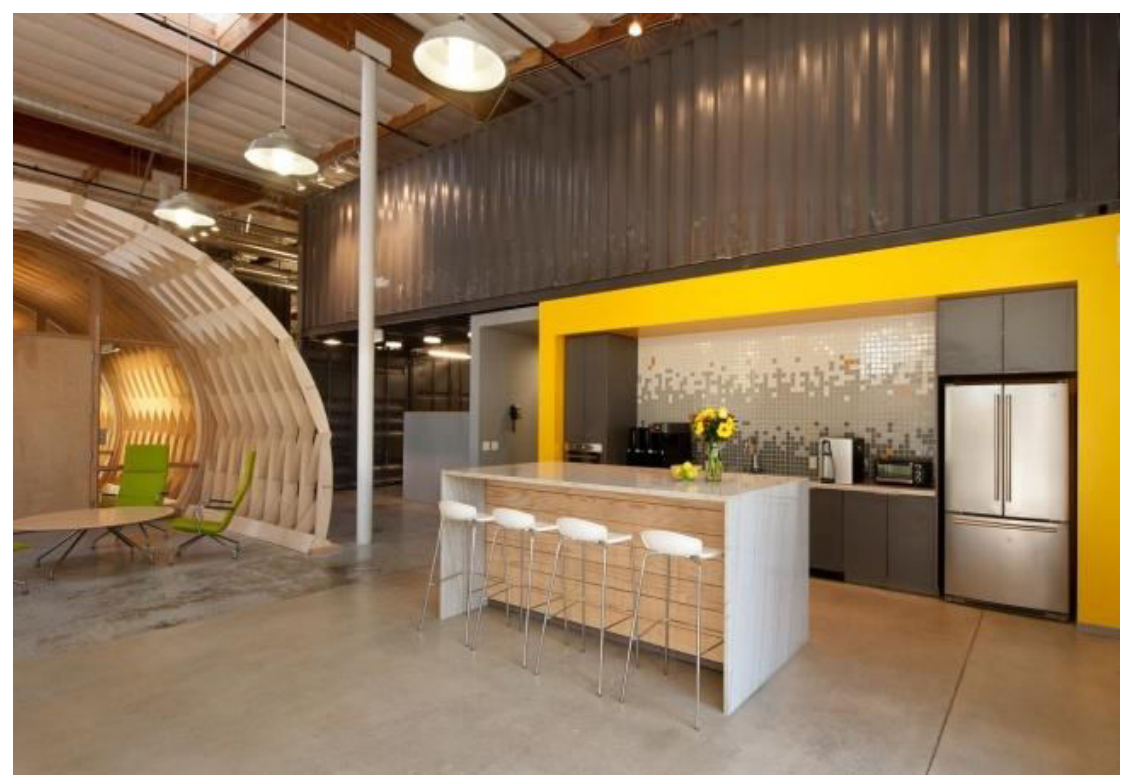

Слика.39. Кујнски простор во канцелариски простор на Кунингам Груп во Лос Анџелес, САД 8

\section{3. Викс (WIX Lithuania)}

Викс претставува глобална ИТ компанија. Предмет на анализа во овој труд претставува канцеларијата на компанијата која што се наоѓ во Вилнус, Литванија. Канцеларискиот простор се состои од простор за вработените, простории за состаноци, простор за одмор и кујнски простор. Во Слика.40 претставен е просторот за вработени. ${ }^{85}$

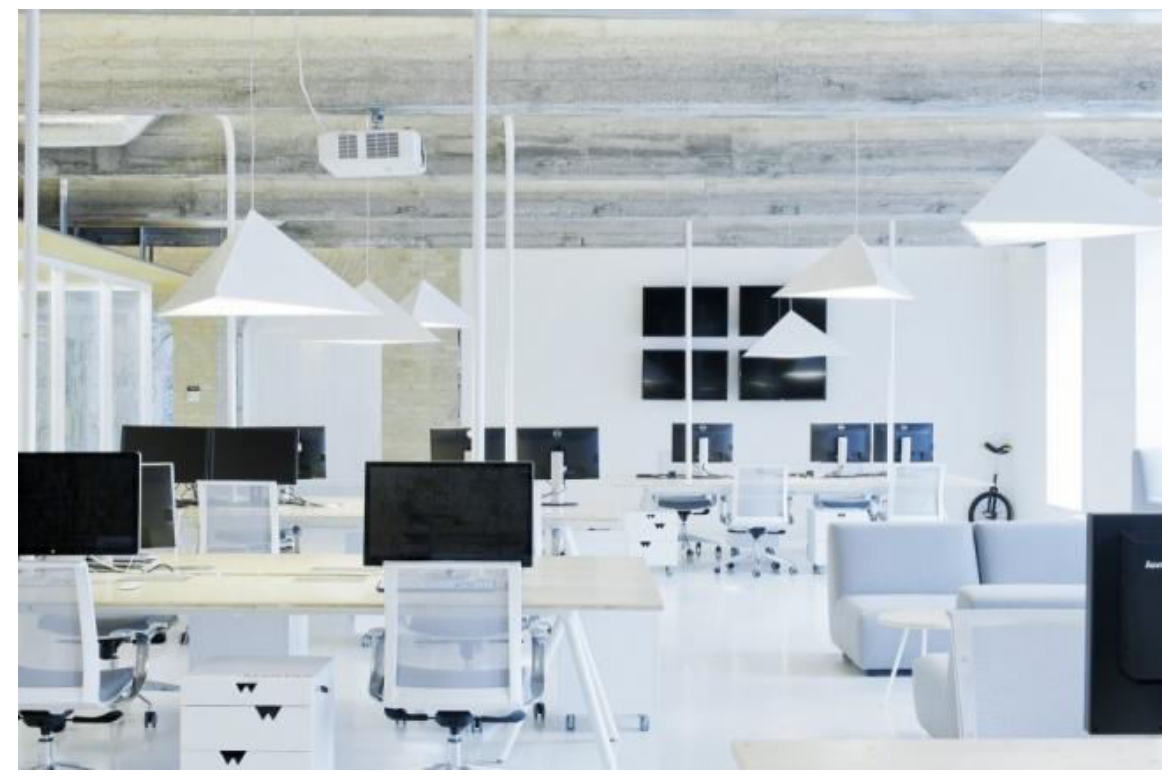

${ }^{85}$ http://www.officedesigngallery.com/2014/o8/o9/wix-lithuania/ 
Анализа на концептите на организација и опремување со мебел кај канцелариските простори магистерски труд Зејнелабедин Азири

Слика.40 Простор за вработени во канцелариски простор на компанијата ВИКС

Просторот за вработени е опремен со работни маси, столици и компјутери за вработените. Просториите за состаноци претставени се во Слика.41 и Слика.42.

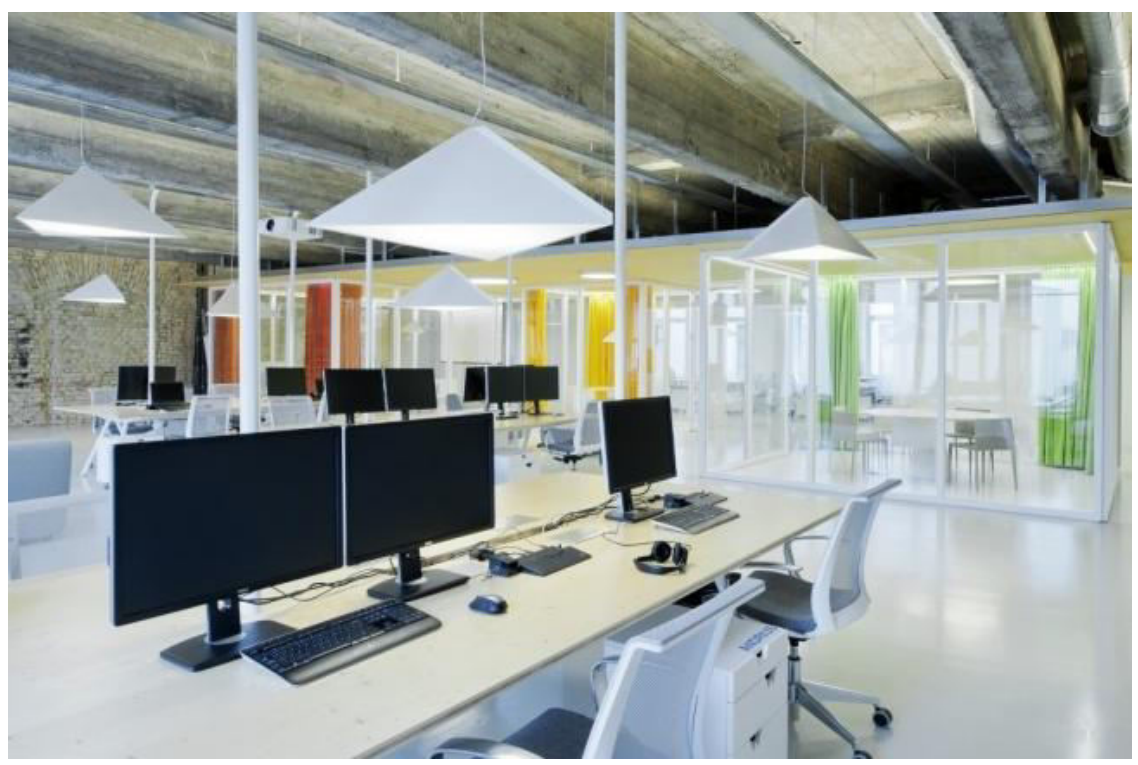

Слика.41 Просторииза состаноци во канцелариски простор на компанијата ВИКС

Во канцеларискиот простор на компанијата ВИКС има три простории за состаноци.

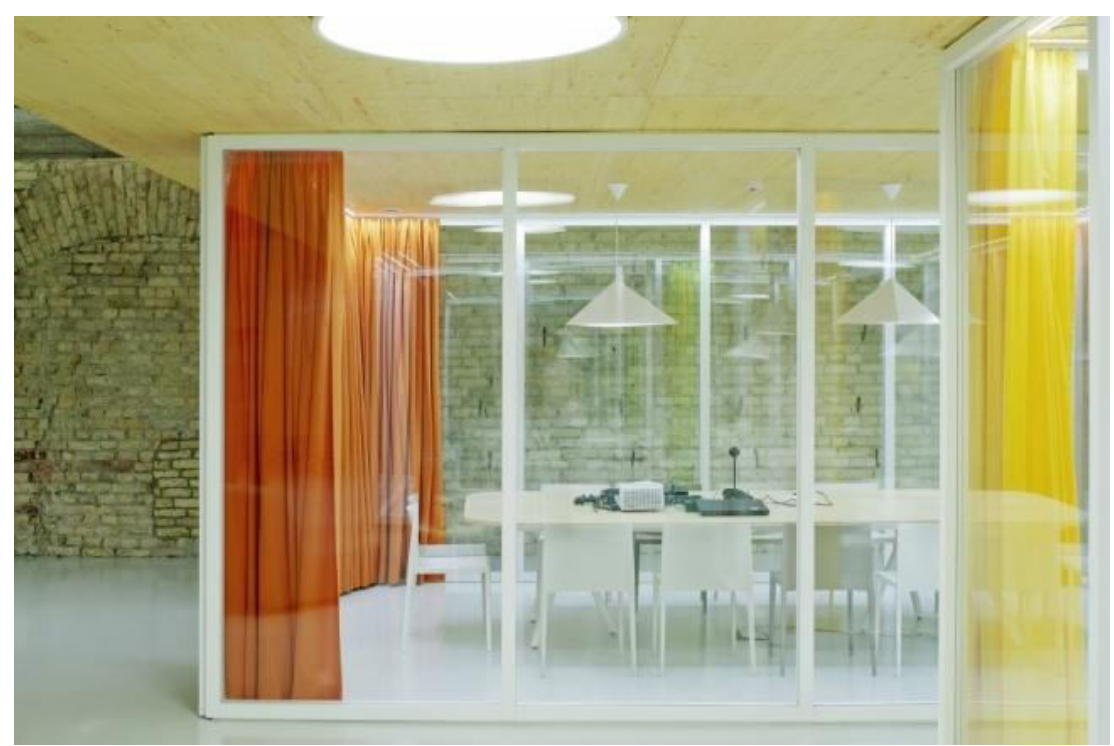

Слика.42 Простор за состаноци во канцелариски простор на компанијата ВИКС 
Анализа на концептите на организација и опремување со мебел кај канцелариските простори магистерски труд Зејнелабедин Азири

Просториите за одмор се претставени во Слика.43 и Слика. $44 .{ }^{86}$

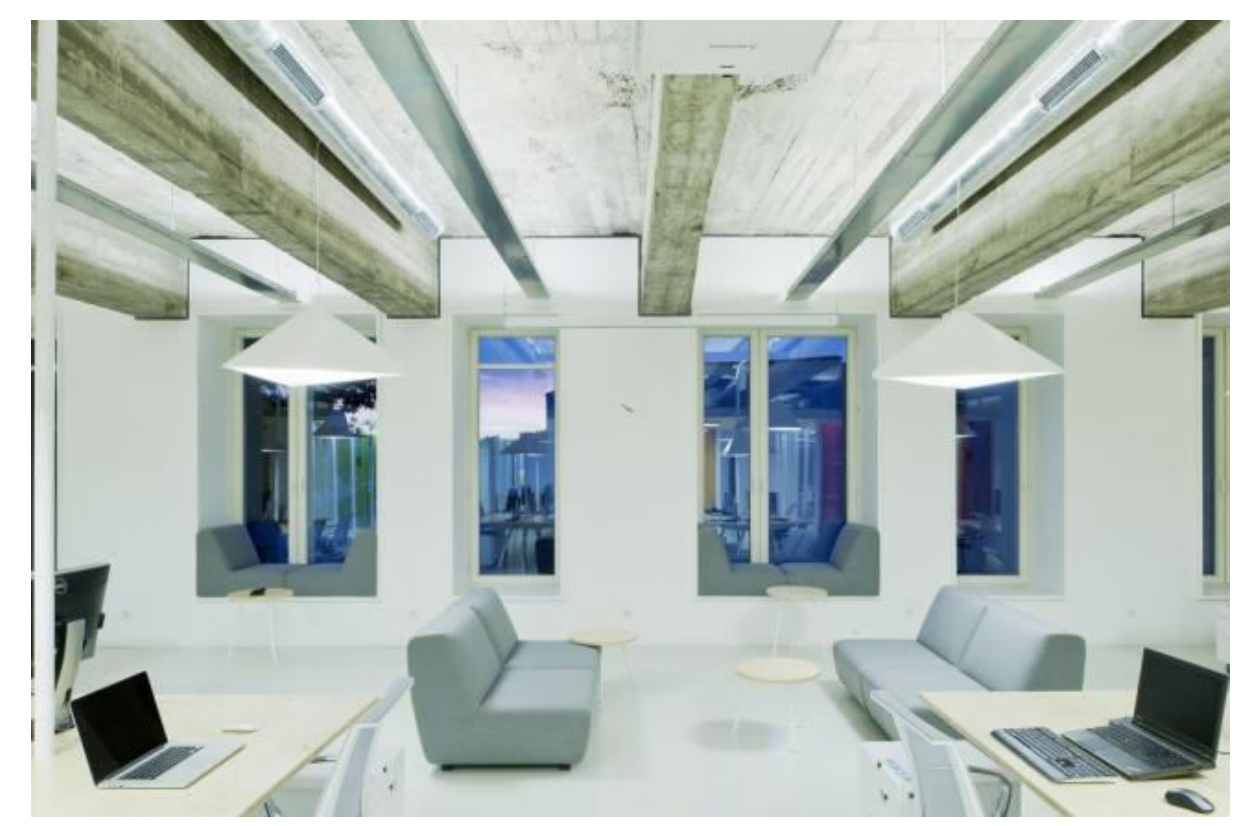

Слика.43Простор за одморво канцелариски простор на компанијата ВИКС

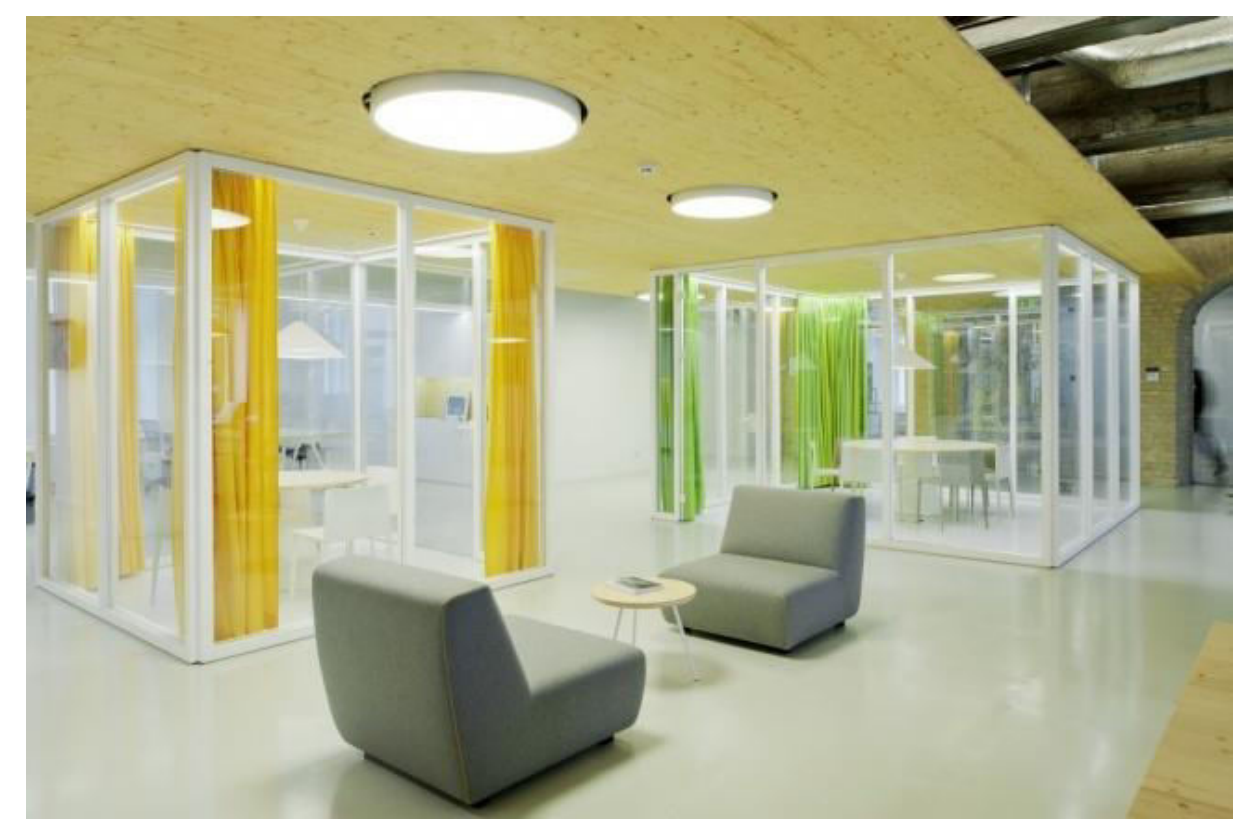

Слика.44 Простор за одмор во канцелариски простор на компанијата ВИКС

\footnotetext{
${ }^{86}$ http://www.officedesigngallery.com/2014/08/09/wix-lithuania/
} 
Кујнскиот простор е претставен во Слика.45.87

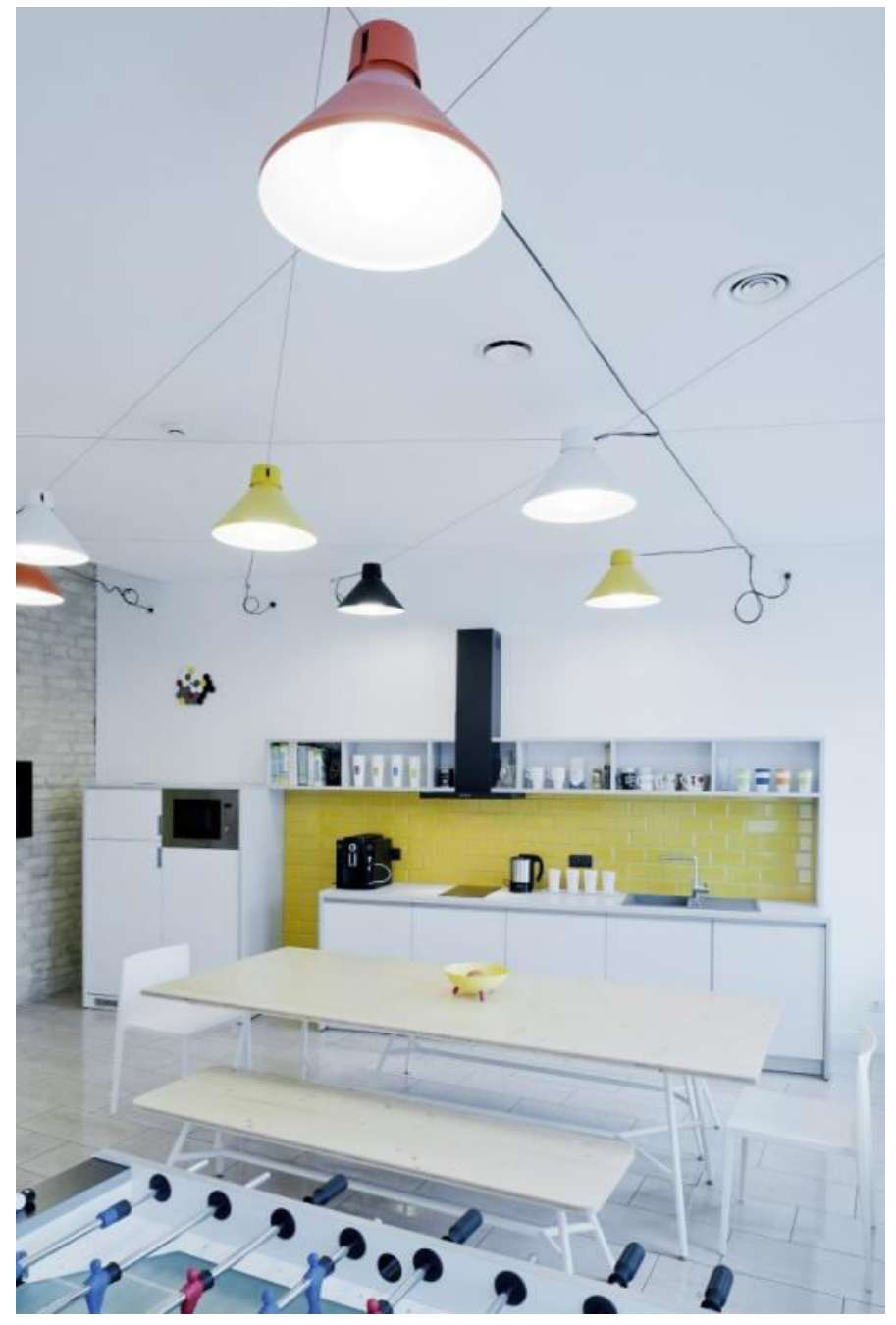

Слика.45Кујнски простор во канцелариски простор на компанијата ВИКС

${ }^{87}$ http://www.officedesigngallery.com/2014/08/09/wix-lithuania/ 


\section{б.Заклучок}

Со овој труд направена е анализа на концептите на организацијата на мебелот и негово опремување во канцелариските простори. Преку анализа на концептите на организација и опремување корисниците би имале детален преглед врз просторот во кој би требало да работат, врз распоредот на мебелот и друг инвентар но и врз начинот на распоред на вработените во фирмата и какви услови се создадени за нив.

Направено е стратешко планирање на просторот, преку кое се анализирани корисниците на канцеларискиот простор и постојниот простор за уредување.

Разработени се два различни пристапи, наменети за две различни деловни структури, објекти и субјекти. Компаративниот пристап за два функционално дивергентни концепта овозможува појасен увид во барањата, можностите и капацитетите на објектот за секоја од конкретно зададените намени. Двете канцелариски простории, предмет на анализа во овој труд, се сместени во Деловно Трговскиот Центар-ДТЦ Мавровка. Едната канцеларија претставува новинска агенција додека другата претставува правна канцеларија. Новинската агенција е дизајнирана во затворен концепт додека правната канцеларија е дизајнирана во отворен концепт. Распоредот на мебелот и останатото уредување варираат во двете варијанти создадени за нив и во многу зависат од анализите на антропометриските и ергономските принципи на проектирање применети во анализата. Целта на ергономските анализи прикажани во трудот е да се добие квалитетен, комфорен работен простор, во кој човечкиот фактор е многу важен.

- Cтратешкото планирање на просторот претставува проактивен пристап кон дизајнот на просторот и негово користење. Овој вид на планирање претставува длабинско анализирање на претпријатијето/организацијата пришто се добива една слика за нејзините цели и големина но исто така и нејзиниот капацитет да ги исполни барањата за ефикасно работење но и идно проширување согласно барањата на пазарот во кој што дејствува. Како резултат на стартешкото планирање, просториите на друштвото ќе бидат со соодветни димензии и соодветно дизајнирани но и нивните обврски ќе бидат исполнети на рентабилен начин (со помал трошок). Во овој труд примената на стратешкото планирање може да се увиди при изборот на локација за новинарската канцеларија и правната канцеларија.

- Процесот на организација на проектот ги дефинира потребите на одреден проект кој што се спроведува во една организација како и неговите цели, учесниците во проектот, нивните улоги и одговорности и дефинира процес на донесување на одлука. Во трудот, накратко дадено е објаснување за најважните чекори кои што би требало да се превземат со цел добро да се планира проектот така што соодветно и ефикасно би се имплементирал. 
Анализа на концептите на организација и опремување со мебел кај канцелариските простори магистерски труд Зејнелабедин Азири

- Преку анализа на ентериерот на канцелариските простори, направен е обид за анализа на дизајнот за канцелариските простори, одделно за двете намени: канцелариски простор на новинска агенција и канцелариски простор на правна канцеларија. Анализата на дизајнот на канцелариските простори во овие два субјекти е спроведена најнапред преку поделба на три делови. Во првиот дел се прави анализа на проценка на големината на потребниот простор. Проценката на големината на потребниот простор е направена преку карактеризирање на факторите кои што влијаат врз големината на потребниот простор како што се дизајнот на објектот, карактеристиките на работата која што се планира да се извршува во канцеларискиот простор, нивото на нужност од помошни простории (на пример, конференциска сала и сл.) и бројот на вработени во тековниот период и во иднина. Додека во вториот дел се прави планирање на канцеларискиот ентериерпреку согледување на следниве шест елементи, структура на внатрешноста на објектот, зидови и прегради, осветлување, под, вентилација и контрола на звук. Во последниот, трет дел, се прави декорација и опремување на канцеларискиот простор преку селектирање на елементи потребни за соодветно извршување на работата како и нивната боја и дизајн.

- Преку анализа на ергономските и антропометриските карактеристики кои го детерминираат седењето и работењето на работното место. Тие параметри се појдовен елемент од кој се тргнува при дизајнирањето на мебелот за опремување на канцеларискте простори. Во овој дел анализирани се 'рбетот и мускулите и нивната положба при седење како, физиолошките критериуми кои што треба да се задоволат со цел да се достигне посакуваниот комфор при седење и проблемите кои што настануваат при неправилно седење. Исто така, направен е преглед на столот како елемент за седење, вклучувајќи ги неговите делови, посакуваните ергономски димензии и додатоци кои што би го направиле седењето повеќе комфорно. На крајот претставени се неколку модели на ергономски комерцијални столови.

- Преку анализа на одделни примери на квалитетно опремен канцелариски простор се овозможува да се увиди различниот пристап при дизајнирање. Периодот кој што е земен во предвид се последниве 14 години односно почетокот на 21 век до денес.Како предмет на анализа на примери од квалитетно опремени канцелариски простори, земени се канцелариските простори на следниве компании,

- Блу Комуникејшн (Blue Communication)

- Кунингам груп (The Cuningham Group)

- $\quad$ Викс (WIX Lithuania) 


\section{7.Библиографија}

1. A. J. S. Lundervold, Electromyographic Investigations of Position and J. C. Robinette, Ergonomics in the Design of Office Furniture, A Review of European Literature, Industrial Medicine and Surgery, v.38, n.4, 1969, pp. 115-125

2. ASHLEY-MONTAGU, M.F. (1960) An Introduction to Physical Anthropology, 3rd Edn, Springfield, IL: Charles C.Thomas.

3. AYOUB M.M. Sitting Down on the job (Properly).Industrial Design v.19 n.3 $197242-45$

4. ANDREW, I. and MANOY, R. (1972) Anthropometric survey of British Rail footplate staff, Applied Ergonomics, 3, 132-5.

5. AKERBLOM,B. Standing and Sitting Posture. Stocholm AB Nordiska Bokhandeln,1948

6. ARMSTRONG, T.J., BUCKLE, P., FINE, L.J., HAGBERG, M., JONSSON, B., KILBLOM, A., KUORINKA, I.A.A., SILVERSTEIN, B.A., SJOGAARD, G. and VIIKARI-JUNTURA, E.R.A. (1993) A conceptual model for work-related neck and upper-limb musculoskeletal disorders, Scandinavian Journal of Work Environment and Health, 19, 73-84.

7. B. Akerblom, Standing and Sitting Posture, Stockholm: A B Nordiska Bokhandeln, 1948

8. BATOGOWSKA, A. and SLOWIKOWSKI, J. (1974) Anthropometric Atlas of the Polish

Adult Population for Designer Use, Warsaw: Instytut Wzornictwa Przemystowego (in Polish).

9. BERYL Robichaud.Selecting planning and managing office space, , McGraw Hill publishing company Inc., 1958

10. BENNETT, C. (1977) Spaces for People: Human Factors in Design, Englewood Cliffs, NJ: Prentice Hall.

11. BRANTON, P. Behavior,Body Mechanics and Discomfort. Ergonomics v.12 n 21969 316-317

12. BOLTON, C. B. Ventile, Incompresible Cushions. Applied ergonomics, V.3 n.2 1972 101-105

13. BS 5940: Part I (1980) Office Furniture: Specification for Design and Dimensions of Office Workstations, Desks, Tables and Chairs, London: British Standards Institution.

14. CARLES BROTO,Office Interiors \& Business Buildings, Linksbooks, Barcelona, Spain

15. CANNON, L.J., BERNACKI, E.J. and WALTER, S.D. (1981) Personal and occupational risk factors associated with the carpal tunnel syndrome, Journal of Occupational Medicine, $255^{-8}$

16. CAIN, W.S. AND STEAVENS J.C. Measurment of muscle Fatigue by Constant-Effort Procedure. Resumes, 4th International Congress of Ergonomics ,Stasbourg 1970

17. Chaffin, D.; Andersson, G.; \& Martin, B.J. (1999). OccupationalBiomechanics, New York: John Wiley \& Sons, 366-370.

18. CORLETT, E.N. (1983) Analysis and evaluation of working posture, in T.O.KVALSETH(Ed.) Ergonomics of Workstation Design, London: Butterworths.

19. DAMON, A., STOUDT, H.W. and MCFARLAND, R.A. (1966) The Human Body in Equipment Design, Cambridge MA: Harvard University Press.

20. E. Grandjean, et al. An Ergonomic Investigation of Multipurpose Chairs, Human Factors, v.15, n.3, 1973, pp. 247-255

21. E. Grandjean, et al., The Development of a Rest Chair Profile for Healthy and Notalgic People, Sitting Posture: Proceedings of the Symposium, Zurich, 1968, London: Taylor and Francis, 1969, pp. 193-201

22. FLOYD,W,F and ROBERT,D.F. Anatomical and Physiological Principles in Chair and table design. Ergonomics v.2 n.1 1958 1-16.

23. FLOYD W.F. and WARD J.S. Antropometric and Physiological Considerations in school,office and factory sitting.Ergonomics v.12 n.2 1969 132-139 
24. FLOYD W.F. and SILVER P.H.S. Patterns of Muscles Activities In Posture and Movment Science News n.22 1951 7-25

25. F.K. Bradford and R.G. Spurling, The Intervertabral Disc: With Special Reference to Rupture of the Annulus Fibrons, With Herniations of the Nucleus Pulpous, Illinois: Charles C. Thomas, 1945.

26. GRANDJEAN ,E Ergonomics of the Homes. LONDON Toylor and Francis , 1973

27. GRANDJEAN, E. and HÜNTING, W. (1977) Ergonomics of posture: review of various problems of standing and sitting posture, Applied Ergonomics, 8, 135-40.

28. НОЈФЕРТ Е ,Архитетонско проектирање, Whitney Library of Design, New York, 1978

29. http://www.bbc.com/news/magazine-23372401

30. http://www.burotime.com.tr/tr/urunler

31. http://en.wikipedia.org/wiki/Office

32. http://www.burotime.com.tr/tr/urunler

33. http://houseandhome.com/design/bathroom-planning

34. http://www.houseplanshelper.com/bathroom-dimensions.html

35. http://www.archdaily.com/335749/hayden-place-cuningham-group/

36. http://www.burotime.com.tr/

37. http://www.burotime.com.tr/tr/urunler/ofis-mobilyalari/toplanti-ofis-mobilyalari/levelstoplanti-ofis-mobilyasi

38. http://www.burotime.com.tr/tr/urunler/ofis-mobilyalari/operasyonel-ofis-mobilyalari/beta

39. http://www.burotime.com.tr/tr/urunler/ofis-mobilyalari/yonetici-ofis-mobilyalari/pure-ofismobilyasi

40. http://www.burotime.com.tr/tr/urunler/ofis-mobilyalari/vip-ofis-mobilyalari/maki-ofismobilyasi

41. http://www.burotime.com.tr/tr/urunler/bekleme-grubu/lobi-bekleme/dem-saloon

42. http://www.burotime.com.tr/tr/urunler/oturma-grubu/kanapeler/dem-ofis-koltugu

43. http://www.hermanmiller.com/products/seating/performance-work-chairs/embody-chairs.htm

44. http://www.hermanmiller.com/products/seating/performance-work-chairs/aeron-chairs.html

45. http://www.hermanmiller.com/products/seating/performance-work-chairs/mirra-2-chairs.html

46. http://www.geigerintl.com/products/seating/task-chairs/foray.html

47. http://www.sitonit.net/productcatalog/focuswork_taskchair.html

48. http://www.steelcase.com/en/products/category/seating/task/gesture/pages/overview.aspx

49. http://inthralld.com/2013/10/the-15-best-ergonomic-task-chairs-for-your-office

50. http://www.officedesigngallery.com/2014/o9/07/blue-communications-agency-office/

51. http://www.officedesigngallery.com/2014/08/09/wix-lithuania/

52. http://www.archdaily.com/335749/hayden-place-cuningham-group

53. J. J. Keegan, Alterations of the Lumbar Curve Related to Posture and Seating, Journal of Joint and Bone Surgery, v.35, n.3, 1953, pp. 589-603

54. J. A. Hanson and F. P. Jones, Heart-Rate and Small Postural Changes in Man, Ergonomics, v.13, n.4, 1970, pp. 483-487

55. K. H. E. Kroemer and J. C. Robinette, Ergonomics in the Design of Office Furniture, A Review of European Literature, Industrial Medicine and Surgery, v.38, n.4, 1969, pp. 115-125

56. Kleeman, W. And Prunier, T., (1980), Evaluation of chairs used by air traffic controllers of the US Federal Aviation Administration, in Easterby, R., Kroemer, K. H. And Chaffin, D. (eds) Nato Symposium on Anthropometry and Biomechanics: Theory and Application, London: Plenum Press

57. Karanakov, Jugoslav, Elementi na proektiranje na mebel, Skripta na Fakultet za dizajn i tehnologii na mebel i enterier

58. LE CORBUSIER (1961) The Modulor: A Harmonious Measure to the Human Scale, Universally Applicable to Architecture and Mechanics, London: Faber \& Faber.

59. LE CARPENTIER, E.F. Easy Chair Dimension For Comfort.Ergonomics,v.12,n.2 327-331 


\section{магистерски труд Зејнелабедин Азири}

6o. Markovac, Ž.., Grbac, I. Ivelic, Ž.," Orthopaedics and orthopaedic furniture", International Conference"Ecological, biological and medical furniture - Fact and misconceptions" Zagreb Croatia, 2000, pp $75-82$

61. MEHMET A. Postural and Physiological Criteria for Seating- A Review METU,Journal of the of Architecture v.1 n.1 Spring 1975

62. OSHIMA,M. Optimum Condition of Seat design. Resume $4^{\text {th }}$ international congress of ergonomics.Stranbourg 1970

63. Office Interiors \& Business Buildings, , Linksbooks, Barcelona, Spain

64. NICHOLSON, A.S., PARNELL, J.W. and DAVIS, P.R. (1985) Bed design for back pain sufferers, in Ergonomics International 85.

65. Nikoljski Panevski,Elena, Vladimir Karanakov, Impact of ergonomics on the design of the workspace, Wood technology\&Product design, International scientific conference, Proceedings Vol.1, Skopje 2013

66. POLLACK ,A,A and WOOD E.H. Venous Presure in the Saphenous Veinat the Ankle. Journal of applied Physiology. V.1 1949 649-662

67. Pheasant, S. (1986). Bodyspace, Philadelphia: Taylor and Francis,129-134.

68. PHEASANT, S.T. and SCRIVEN, J.G. (1983) Sex differences in strength: some implications for the design of hand tools, in K.COOMBES (Ed.), pp. 9-13,Proceedings of the Ergonomics Society's Conference 1983, London: Taylor \& Francis.

69. PHEASANT, S.T. and STUBBS, D. (1992a) Back pain in nurses: epidemiology and risk assessment, Applied Ergonomics, 23, 226-32.

70. PHEASANT, S.T. and STUBBS, D. (1992b) Lifting and Handling: An Ergonomic Approach, London: National Back Pain Association.

71. PILE John F.Open office planning, The Architectural Press Ltd, 1978

72. STEPHAN, P., Anthropometry, Ergonomics and the Design of Work, Taylor \& Francis, 2003

73. ROBERTS, D.F. (1973) Climate and Human Variability: An Addison-Wesley Module in Anthropology, No. 34, Reading, MA: Addison-Wesley.

74. RAYFIELD K. Office Interior Design Guide, Julie, стр.4 и 5

75. Springer, T.J., (1982), Visual Display Terminals: A comparative evaluation of alternatives. State Farm Mutual Automobile Insurance Company, Bloomington, Illinois, March

76. The offices of the future, Tasarım-Review of architecture design and visual arts, Tasarim publishing group, Istanbul, Turkey

77. The Ergonomic Seating Guide Handbook, Haworth, pp. 8

78. TILLEY, R.A. (2002) The Measure of Man and Woman, John Wiley\&Sons, New York.

79. The Ergonomic Seating Guide Handbook, Haworth, pp. 5-6

80.Tyrrell, A.R.; Reilly, T.; Troup, J.D. (1985). Circadian variation instature and the effects of spinal loading. Spine 10(2), 161-164.

81. U.S. Department of Energy, Office Ergonomics Employee Handbook, http://wwwesh.Fnal.gov/CourseHandout

82. Mat/Computer_Workstation_Ergonomics_FNoo0324/Office_Ergo_Handbook.pdf

83. WOODSON, W.E. (1981) Human Factors Design Handbook, New York: McGraw-Hill.

84. WOODSON, W.E. and CONOVER, D.W. (1964) Human Engineering Guide for Equipment Designers, Berkeley: University of California Press. 